LOCAL GOVERNMENT INVOLVEMENT IN LONG TERM RESOURCE PLANNING FOR COMMUNITY ENERGY SERVICES

\title{
DEMAND SIDE MANAGEMENT
}

\section{Energy Task Force}

of the Urban Consortium for Technology Initiatives

\section{DISCLAIMER}

This report was prepared as an account of work sponsored by an agency of the United States Government. Neither the United States Government nor any agency thereof, nor any of their employees, makes any warranty, expres or implied, or assumes any legal liability or responsibility for the accuracy, completeness, or usefulness of any information, apparatus, product, or process disclosed, or represents that its use would not infringe privately owned rights. Refer. ence herein to any specific commercial product, process, or service by trade name, trademark, manufacturer, or otherwise does not necessarily constitute or imply its endorsement, recommendation, or favoring by the United States Government or any agency thereof. The views and opinions of authors expressed herein do not necessarily state or reflect those of the United States Government or any agency thereof.

\section{CITY OF TUCSON}


PREFACE

\section{URBAN CONSORTIUM ENERGY TASK FORCE RESEARCH}

THE URBAN CONSORTIUM (UC) is a special network of the Nation's largest cities and urban counties brought together by PTI to find new solutions to their common concerns. The UC provides a creative forum where elected and appointed officials can identify, test, and validate practical ways to improve the provision of public services while generating new revenue opportunities. With staff, management, and business services provided by PTI, the UC addresses the critical needs of large local governments through its three task forces: Energy, Environment, and Telecommunications and Information.

The Urban Consortium Energy Task (UCETF) has 20 members and was established to improve urban energy management and decision-making through applied research and technology transfer. The UCETF focuses on developing and sharing new approaches and innovative solutions to energy management problems with local governments. Projects are organized in thematic units and co-managed by a member of the Task Force.

A description of the 1991 program Units and projects are:

\section{ALTERNATIVE VEHICLE FUELS AND TECHNOLOGIES (AVF)}

Alternative vehicle fuels offer a very strong potential to aid in the reduction of U.S. dependence on foreign oil supplies, with the resulting benefits of decreased air pollution in urban areas. Local governments can play an instrumental role in realizing this potential through practical applied research and highly visible demonstrations of altemative fuels and technologies. Issues addressed this year include identifying (a) intensive and credible market development efforts based on an applied research and demionstration program that combines reliable technology with experience-tested applications, environmental and energy diversity benefits, and (c) institutional and infrastructure barriers. The 1991 AVF unit consists of:
Broward County, FL -. Dual-Fuel Conversion Demonstration and Technology Transfer Project

New York City, NY - Alternative Fuel

Vehicle: Financing Issues

Denver, CO -. Technical and Market Comparison Berween H2/CNG (Hythane), Electric Hybrid, and CNG Fueled Vehicles

Denver, CO - An Alternative Fuels Fleet Evaluation System - A Transfer Project

Detroit, MI -- Analysis of Institutional and International Limitations for Alternative Fuel Vehicles

Washington, DC -. Comparison of Energy Consumption. Energy Savings, and Environmental Effects of EVIPV vs. Conventional Gasoline Vehicle

\section{ELECTRICITY MANAGEMENT}

Urtan interests for electricity management focus on means to maintain stable, secure and reasonably priced supplies of electric energy. Approaches include procedures for better demand management, application of "least cost" planning concepts, appropriate use of decentralized and/or small power production facilities, improved end-use efficiency, and developing sound structures for cooperative action among municipalities and energy urilities. Urban strategies include support for decentralized "small" power production, along with better demand management and improved end-ur: energy efficiency. The successful development and implementation of such strategies will require close cooperation with the utility industry and will address topics in areas of institutional relations, source flexibility, and demand-side management. The 1991 Electricity Management Unit consists of:

Albuquerque, NM -. Aliernatives to Traditional Rate Setting

Chicago, IL -- Integrating Innovative Supply and Efficiency Techniques

Chicago, Il -- The Chicago Energy

Dade County, FL -- Energy Cost Reduction Through Resource Recovery 
Detroit, MI -- Hydraulic Waste Energy Recovery (Phase II) City of Detroit Water Distribution System

San Jose, CA -- Utility/Local Government Partnership to Increase Energy Conservation in New Construction

\section{ENERGY EFFICIENT FACILITIES}

Activities involving energy efficient facilities are at present, part of a national effort to achieve maximum cost-effective energy productivity in the building sector. There exists a need for collaboration between local government officials responsible for energy and environmental programs and other local government officials responsible for facilities, as well as the Federal officials and private sector groups, e.g. utilities. New technologies and management/administration practices to advance energy efficiency in facilities require major partnership efforts and transfer programs. Multi-family housing that has a large concentration of low-income families presents a unique challenge to lowering energy costs and maintaining energy efficient facilities. Projects in this unit are:

Boston, MA -- Neighborhood Energy Efficiency Outreach Partnership

Columbus, $\mathrm{OH}$-- Energy Efficiency and Indoor Air Quality: Solutions for Fire Stations

Louisville, KY .. Partnership Approach to Energy Efficiency in Non-Profit Facilities

Montgomery County, MD -- Technology Transfer of Building Energy Design Guidelines

New Orleans, LA .- Residential Utility Costs Comparative Study

Phoenix, AZ -. Variable Frequency Drive Applications Guide

Portland, OR -- Energy Savings Through Operation and Maintenance Training in the Low-Income Multi-Family Sector

Washington, DC -. Comparison of Two Techniques for Identifying Energy Conservation Measures in Low Income Homes

\section{ENERGY, ENVIRONMENT and ECONOMIC DEVELOPMENT}

This an area that has both visionary and immediate practical emphases on the definition and evaluation of realistic strategies and actions to support energy-sustainable and environmentally responsible communities. Emphases include uses for renewable energy, practical domestic supply and conservation altematives, and the synthesis of energy concerns with wider local government interests in economic development, environmental quality, and internal cost control. Urban strategies to improve energysustainability require attention to both broad based institutional changes, as well as specific projects designed to encourage the application of appropriate technology and community development practices. The "Sustainable Communities" project has involved three municipalities with State agency, Lawrence Berkeley National Laboratory, and a formal advisory committee with broad national representation. Projects under this unit are:

Austin, TX -. Energy Star Sustainable Rating Program

Phoenix, AZ -. Impact of Heat Island on Cooling and Environment: A Demonstration Project

Pima County, AZ -- Tucson Solar Village - Project Management

Portland, OR - Sustainable City Transfer Project

San Francisco, CA -. Neighborhood Energy/Economic Development at South Bayshore

San Francisco, CA -- Sustainable City Transfer Project

San Jose, CA -- Sustainable City Transfer Project

Seattle, WA - Coordination of Energy and Air Quality (CEAM)

Seattle, WA -- Bicycle Program -- Urban Trails System

Tucson, AZ -. Local Government Involvement in Long Term Resource Planning for Community Energy Services

Reports from each of these research projects, including this report, are specifically designed to aid the transfer of proven experience to other local governments. Readers interested in obtaining any additional reports or further information about the Urban Consortium Energy Task Force and the Urban Consortium should contact:

Energy R\&D Program

Public Technology, Inc.

1301 Pennsylvania Avenue, NW

Washington, DC 20004

1-800-852-4934 


\section{ACKNOWLEDGEMENTS}

The originator of this project was Karen J. Heidel, Resource Manager for the Office of Energy and Environment, City of Tucson, and Director for this project. Burton E. Waite Jr., Energy Coordinator, Office of Energy and Environment, City of Tucson, was the project manager and principle staff responsible for all aspects of the project.

Project staff wish to express appreciation to all who helped bring this project to a successful conclusion. A special thanks are due to Tucson Electric Power corporation for there development of the Commercial and Industrial Lighting Efficiency Program.

We wish to express our sincere thanks to the Department of Energy, the Energy Task Force of the Urban Consortium, and the City of Chicago for the administration of the Energy Technology Grant. 


\section{CONTENTS}

CHAPTER 1 - OVERVIEW Page

Abstract 1

Project Purpose 3

Organization of Guide 5

CHAPTER 2 - GENERAL BACKGROUND AND DESCRIPTION

Energy Use in Tucson's Commercial Sector 6

Potential Small Commercial Business Energy Savings 10

Long Term Resource Planning 15

CHAPTER 3 - WORKING WITH THE CHANGING UTLLITY INDUSTRY

History 19

Commercial Lighting Programs Receive Major Focus 19

Regulatory Changes $\quad 21$

Least-Cost Planning 21

Incentive Mechanisms $\quad 22$

DSM Potential 24

Implementation Options $\quad 25$

Tucson Electric Power Pilot Commercial and Industrial

CHAPTER 4 - LESSONS LEARNED

Future Rate Design $\quad 28$

Future Programs and Research 41

\section{APPENDIX}

A - Bibliography 45

B - Tucson Electric Power Company Pilot Commercial and
Industrial Lighting Efficiency Program

C - Sources of Lighting Information and Services $\quad 80$

TABLES

1 - Potential Energy Savings for Selected Conservation Measures 12

2 - Potential Energy Savings for Certain Conservation Measures in Tucson's Commercial Sector 14

3 - Planning for Stable Growth - Available Megawatts 16

4 - Planning for Stable Growth - Cost 17

5 - Tucson Electric Power Company Rate Summary 29

6 - Metropolitan Areas and Associated Companies 31

7-10 - Average Rate Comparisons of Metropolitan Areas 32

11 - Electricity Purchases as a Percent of Output by Sector 37 


\title{
TITLE: LOCAL GOVERNMENT INVOLVEMENT IN LONG TERM RESOURCE PLANNING FOR COMMUNITY ENERGY SERVICES
}

\section{CHAPTER 1 - OVERVIEW}

\begin{abstract}
This project was designed to address a common problem which has been identified by a number of national and local agencies, as a specific shortfall in the network of energy conservation services. While numerous service opportunities exist for residences, and large commercial and industrial facilities have access to in-house energy expertise, small to medium sized commercial businesses tend to remain unserviced. Also, the trend toward energy conservation programs needs to be focused on total energy including source efficiency. This is away from the usual focus of electricity management only.
\end{abstract}

In the past decade, both electric utilities and state regulators have recognized the tremendous potential economic benefits to an electric utility system from reducing peak load and base energy requirements through lower cost alternatives to new power plant construction. The primary alternative encouraged by regulators and adopted by utilities has been the initiation and implementation of "Energy Efficiency" or "Demand Side Management" (DSM) programs. This has been particularly effective where the local electric utility has or is about to experience capacity problems (brown-outs) and has a real personal corporate financial interest in DSM. Combined with the fact that consumption of unrenewable resources (gas, propane, coal, and oil) is typically not addressed and the fact that the local electric utility that services the City of Tucson franchise area has excess power capacity, project management decided to pursue resource planning state wide, including environmental benefits, through conservation and resource demand management. 
Data acquisition on existing DSM programs indicated that most utility programs are in the lighting area and consist of some form of informational audit coupled with rebates for installation of efficient lighting technologies identified within the audit recommendations. Despite wide-spread popularity of these programs, participation rates among eligible utility customers have generally been low (1\% to $20 \%)^{1}$. One unusual program that stands out among the rest is that of Taunton Municipal Lighting Plant (TMLP) in Taunton, MA. which is experiencing a $95 \%$ sign up rate. According to TMLP, the common thread which tied their successful program together was the face-toface contact with the customers by someone who is trusted by the business community. The \#1 trusted contact is someone in their exact line of work. The $\# 2$ trusted contact is local government. Therefore, most of our research time and effort went toward establishing the City of Tucson as an expert source for information and analysis of Resource Planning and Demand Side Management.

This direction put the City in a position to influence the establishment of a combined City, Utility, and Arizona Corporation Commission (ACC) effort toward Resource Planning. This combined private/governmental partnership has established a conservation and energy efficiency fund for the purpose of establishing a DSM Program. The second influential factor of this partnership was to involve the traditional lighting product distributors and electrical contractors into program design and implementation. This involvement helps keep a strong focus on the small to medium commercial businesses by involving yet another trusted contact. The City of Tucson provided technical analysis and recommendations to the ACC on Tucson Electric Power's (TEP), Demand Side Management Lighting Conservation Program. National estimates show that $25 \%$ of a electric utilities peak demand is directly attributable to the lighting load from its commercial and industrial customers. Using TEP's peak as a reference, this equates

'Lightwaves Lighting Energy Management Program. Taunton Municipal Lighting Plant, P.O. Box 870, Taunton, MA 02780-0870. 
to $151 \mathrm{Mw}$ of $\mathrm{load}^{2}$. Assuming that only $50 \%$ of that load can be encouraged to participate in a conservation program, there is a potential demand reduction of $30 \mathrm{Mw}$ in lighting alone.

Financially struggling TEP, has been granted a reprieve from U.S. Bankruptcy Court. Creditors sent a letter to the Governor Office explaining the extension and their willingness to meet with the Governor or the Governors Aids to discuss ways to best serve the interests of the residents of Arizona, TEP, and TEP Creditors. In light of the above situation it has been very difficult to keep TEP focused on the development of a DSM Program. To ensure that the focus is not lost no matter what the outcome is for TEP, the City focused a great degree of effort toward the Utilities Division of the ACC. This effort is now blossoming into a potential DSM program for the Natural Gas Utility.

\section{PROJECT PURPOSE}

The purpose of this project was to develop a program to coordinate governmental, research, utility, and business energy savings efforts, and to evaluate future potential actions, based on actual field data obtained during the implementation of phase 1 of the State Resource Plan. This has lead to the establishment of a state conservation and energy efficiency fund for the purpose of establishing a DSM Program. By taking a state wide perspective on resource planning, additional savings, including environmental benefits, can be achieved through further conservation and demand management. This effort has already blossomed into a state directive for DSM programs for the natural gas industry.

2Pilot Commercial and Industrial Lighting Efficiency Program. Tucson Electric Power Company, 4350 East Irvington Road, P.O. Box 711, Tucson, AZ 85702 
As a result of the above resource planning, the following should occur over the next ten years: $\quad$ - Public involvement in resource planning

- A wider perspective for utility planning integrating the total costs of alternatives, not just utility costs.

- A more diverse mix of generation technologies, including solar power

- Reduced environmental degradation associated with power production

- Actions to reduce the costs of electric energy services through economical conservation

- Improved forecasting techniques

- Recognition of the uncertainty in planning 


\section{ORGANIZATION OF THE GUIDE}

Chapter 1 -- $\quad$ An abstract and overview of the document.

Chapter 2 --

General background and description of energy use in Tucson's commercial sector and what lead to long term resource planning.

Chapter 3 --

Working with the changing utility industry and Tucson Electric Power's Pilot Commercial and Industrial Lighting Efficiency Program.

Chapter 4 -Lessons learned from working with the utility on future rate design and future programs and research.

Appendices --
A bibliography of all footnotes and Tucson Electric Power Comvany Pilot Commercial and Industrial Lighting Efficiency Program, and sources of lighting information and services. 


\section{CHAPTER 2 - GENERAL BACKGROUND AND DESCRIPTION}

\section{ENERGY USE IN TUCSON'S COMMERCIAL SECTOR}

A 1990 report entitled Sampling of Energy End Use in Tucson's Small Commercial Buildings provided a general background and context for the quantitative numbers of small to medium commercial businesses that were not being serviced by the existing conservation programs. The purpose of the study was to obtain specific information about energy use attitudes and characteristics of small to medium size commercial businesses in the Tucson-Pima County area, which could be provided to government leaders, the business community, and utility's to enhance energy conservation planning and action programs. Conclusicns derived from this report were as follows:

1. The proportion of small commercial business spaces with owner-occupants that are paying their own electric bill is about forty percent (40\%). Since these owneroccupants can perceive this monthly cost for electricity as a debit against gross profit, they can reasonably be expected to have substantial built-in motivation to adopt costeffective energy conservation measures and to represent, as a group, the potential for a substantial reduction in energy use.

To a certain extent, the same may hold true for the thirteen percent (13\%) where the electric bills are paid by an absentee owner or representative thereof.

The remaining forty-seven percent (47\%), non-owner occupants who pay their own electric bills, could reasonably be expected to be less likely to adopt energy conservation measures unless they involve no capital investment or low capital investment with a short payback period.

2. Thirty-two percent $(32 \%)$ or 137 of the business people surveyed indicated regular attendance at meetings of 148 business, professional, or trade organizations. A

\footnotetext{
${ }^{3}$ Sampling of Energy Use in Tucson's Small Commercial Buildings, Arizona Energy Office, Department of Commerce, 3800 North Central Ave., 12th floor, Phoenix, Az 85012.
} 
multitude of target audiences for energy conservation programs may exist here, providing outlets for diffusion of energy information among people with similar interests.

3. The survey results reveal that to varying but substantial degrees, the respondents see room for improvement in energy efficiency, are willing to spend money for such measures, and are willing to have the payback period be three years or more. In short, a latent market exists for energy conservation education and technology within Tucson's small commercial sectoi.

4. Only seven percent $(7 \%)$ of the survey respondents had received an energy audit or evaluation, but among those who had, a large majority of the measures specifically recommended were implementer as a result of the audit. It is felt that many of those who had an audit may have had a predisposition toward conservation; nonetheless, this rate of response and follow-up action is considered very high, and suggests that expansion of the energy audit ogram, via advertising, could result in substantial energy savings and/or incentives.

5. Results of the study indicate a widespread attitude that energy use and conservation on a national scale is a concern. The corollary to this attitude is the extent to which the small business entrepreneur is able and/or willing to invest funds, time, or energy in conservation measures.

6. In about seventy-two percent ( $72 \%$ ) of the business spaces, the employees have control over the heating system thermostat. The same is true for the cooling thermostat. In these cases, the installation of simple lock-boxes could result in considerable energy savings with little investment required.

7. Averaged figures for the Tucson small businesses surveyed show the following:

Average square feet of business space:

$2,080 \mathrm{ft} 2$

Average annual electricity use:

$35,036 \mathrm{KWH}$

Average cost per year for above:

$\$ 3,153$

Average use per unit area:

$24.9 \mathrm{KWH} / \mathrm{ft} 2$

8. Within the survey population, a significant percentage of the heating equipment [twenty-four percent $(24 \%)$ ] and c'soling equipment [nineteen percent (19\%)] 
gets serviced only when it fails. A minimum of sixteen percent $(16,0)$ of the business spaces are cooled entirely with air conditioning equipment that gets serviced only when it fails. Simple maintenance procedures perform t by an empioyee or via a maintenance contract could significantly affect the operating efficiency of this equipment, with a resulting savings in energy.

9. When asked to rank the importance of a series of characteristics relevant to choosing a possible new space for their business, very few respondents ranked "energy use or conservation" as the most important factor. Many considered it the least important. Demand for the construction of more energy-efficient spaces for small businesses like those surveyed is clearly not being generated by this sector of business space users. If the community wishes to insure that newly constructed business spaces are more energy-efficient, it may need to require minimum standards via building code requirements.

Using the above conclusions as a guide, the following recommendations were derived:

1. Within the small commercial sector, slightly over half of the electric bills are paid by the owners of the business space. It is recommended that planning agencies target this group for both energy audits and infornation about energy-conserving options, including those which require capital invesiment and have a longer payback period.

For the remaining group in which the electric bill is paid by someone who rents or leases the space, it is suggested that energy information and audit recommendations emphasize no-cost, behavioral options or low-cost options with a short payback period.

2. As three-fourths of the small businesses pay their own utility bills, it is recommended that information and programs directed toward that sector be focused on energy options which can further reduce their energy expenditures, especially since at least one-half the respondents felt that some improvement could be made in their energy efficiency.

3. It is recommended that agencies direct informational programs toward a number of the most frequently mentioned business or trade organizations (148 in all) attended by small business people, and that those people be encouraged to diffuse word 
to their associates about their successful or cost-effective energy conservation experiences.

4. As most respondents indicated a willingness to invest only small amounts, at relatively short payback periods, for energy saving options, it is recommended that program emphasis be given to options which incur little or no capital investment, specifically those options which require "behavioral" rather than "structural" modification.

5. Owing to a large $(80 \%)$ positive response to energy audits in terms of implementing the audit recommendations, it is recommended that energy audits be made available and attractive to the small commercial sector to the greatest extent possible. Since Tucson Electric Power is considered by most of the respondents to be the mos reliable local source of information on energy conservation, it is recommended that any actions taken to increase the attractiveness of commercial energy audits include their involvement.

6. With respect to future research, the following recommendations are made:

(a) Explore incentive structures to make commercial spaces for sale, rent or lease more energy efficient and therefore more attractive to small business entrepreneurs.

(b) Explore the impact of retrofits of aged or broken equipment with more energy efficient equipment in small commercial establishments.

(c) Explore the impact of retrofits of non-equipment aspects of older buildings with capital improvements that will be cost effective.

(d) Concust physical surveys of existing small commercial buildings relative to energy end use, stressing unit savings for specified conservation measures and adjusting for localized (Tucson) conditions. 
7. Integrate all new small commercial building energy data and information into the Pima County Geographical Information Survey ("IMAGIN") system and include older buildings in the data base.

\section{SOURCES OF DATA}

1. Survey of 424 small businesses in the Tucson area, conducted by telephone interviews.

2. Local heating and cooling contractors.

3. Local utilities, principally Tucson Electric Power Company.

4. Published literature, and telephone inquiries with out-of-state utilities, agencies, and researchers.

\section{NATURE OF FINDINGS}

1. Information about business space and mechanical energy conservation measures.

2. Information about occupants (owner or tenant), their attitudes toward conservation, and behavioral energy conservation measures.

3. Statistical relationships between energy conservation measures and characteristics of business space and occupants.

4. Interrelationships between various conservation measures in place.

5. Interrelationships between selected characteristics of businesses.

6. Information related to potential energy and dollar savings on a community-wide basis, through selected conservation activities.

\section{POTENTIAL SMALL COMMERCIAL BUSINESS ENERGY SAVINGS}

It is useful, on a community level, to assess the quantity of energy and/or money savings that would be possible if conservation measures were to be more fully implemented. Some of the information developed during this study can be applied toward making a partial estimate of potential energy savings in the greater Tucson community. 
Table 1 lists such savings from sources as cited, for a series of conservation measures which were addressed in the survey questionnaire in the areas of lighting and heating/cooling. The questionnaire was designed further to provide some basis for expanding the individual savings to cover the population of businesses in the community, as is further illustrated by Table 2. It is to be noted that, from the viewpoint of the individual business, the figures in Column 5 of Table 2 represent gross savings, not net savings, since the business must incur some cost to initiate each measure. More importantly, from the viewpoint of the community, since three-fourths of all energy expenditures leave the community, these savings represent a real gain to the local economy in the form of additional dollars retained and recirculated within the community.

It should be noted, too, that the savings shown in Table 2 are not always additive within categories but represent alternatives within a category (such as lighting). However, by adopting the most feasible measures within each category, the total savings is significant; using the most conservative percentage-savings in Table 1, one can project a reduction of about fifteen percent (15\%) in total electrical energy due to lighting measures and seven percent (7\%) due to cooling measures. Thus if a three percent (3\%) savings can be achieved in all other uses, a total of twenty-five percent $(25 \%)$ savings appears to be within the feasible range. 
Table 1. Potential Energy Savings for Selected Conservation Measures ${ }^{4}$

(1)

Conservation Measure

\section{LIGHTING:}

Reduce number of bulbs by $50 \%$

Incandescent to fluorescent

Lower wattage fluorescent

\section{HEATING/COOLING:}

Raise thermostat setting for cooling

Lower thermostat setting for heating

Off-hour setback for cooling

Off-hour setback for heating

Excluding employees from thermostat controls

Maintenance on air conditioning unit
(2) Savings ${ }^{5}$

$50 \%$

$30-50 \%$

$75 \%$

$12-15 \%$
(3)

Source Code ${ }^{6}$ $\begin{array}{ll}13 \% \text { or } & 2 \\ 16 \% \text { or } & 3 \\ 0.38 \text { to } 0.75 \mathrm{kWh} / \mathrm{ft} 2 / \mathrm{yr} & 6\end{array}$

$33 \%$ (4.7\% per degree) 3

$20 \%$

3

about $15 \%$

about $30 \% \quad 8$

about $50 \%$

about $50-60 \%$

$5-15 \%$

$3-11 \%$

4

4

$28 \%$
6

1

6

6

6

3

6
3
3
8
8
4
5




\section{Codes for Sources}

Source Code Description of Source

1 "Commercial Sector Electric Efficiency Measures in Arizona: Their CostEffectiveness and Market Potential" by Skip Laitner and Donald Macke, Economic Research Associates, 1044 H Street, Lincoln, Nebraska, February, 1988.

2 "Guidelines for Saving Energy in Existing Buildings, Building Owners" and Operators' Manual, ECM-1" prepared by Dubin, Mindell and Bloom Associates, U.S. Dept. of Commerce, NTIS, PB-249928, June 1975.

3 "Reducing Energy Costs in Small Businesses" by the IMR Corporation, Reston Publishing Co., 1983.

4 "Energy Management" by Victor Ottaviano, Ottaviano Technical Services, Inc., 1983.

5 "Consumer Reports - Money-saving Guide to Energy in the Home," Doubleday and Co., Inc., Garden City, N.Y., 1978.

6 "Commercial-Sector Conservation Technologies," by Anthony Vsibelli et. al., Lawrence Berkeley Laboratory (LBL 18543), 1985.

7 "Two Techniques for Selling Energy Management" by James Whalen, in Heating/Piping/Air Conditioning, September, 1983.

8 Data provided by Honeyweil Inc. 
Table 2. Potential Annual Energy Savings for Certain Conservation Measures in Tucson's Small Commercial Sector

(1)

(2)

$\begin{array}{ll}\text { Conservation } & \text { Energy Savings } \\ \text { Measure } & \text { per Business } \\ \text { (From Table 1) } & (\mathrm{KWH} / \mathrm{hr})^{7}\end{array}$

\section{LIGHTING:}

Reduce number of bulbs 5,000

(3)

Potential No. Businesses in Commercial Population

(4)

Potential

Energy Savings in

Community (KWH/yr)

(Col. $2 \times$ Col. 3$)$
(5)

Potential

Dollar Savings in Community, at $.09 / \mathrm{KWH}$ for Electrical Energy

Incandescent to
fluorescent
Lower wattage
fluorescent

4.427

2,486

4,178

$8,356,000$
$\$ 1,992,000$

$\$ 2,797,000$

$\$ 753,000$

HEATING/COOL.ING:

\author{
Raise setting \\ thermostat \\ for cooling \\ 1,300 \\ Lower thermostat \\ setting for \\ heating \\ Off-hour setback \\ for cooling \\ 1,500 \\ Off-hour setback \\ for heating \\ Excluding employee: \\ from tbermostat \\ controls \\ Maintenance on \\ air conditioning 2,900
}

631

946,500

$\$ 85,000$

970

7Percentage savings from Col. 2. Table 1, multiplied by totai energy use in lighting $(16,700 \mathrm{KWH} / \mathrm{yr})$ or in hearing/cooling $(10,200 \mathrm{KWH} / \mathrm{yr})$ averaged from this survey (See Average Annual Electricity Use of 35,036 KWH, in Conclusions)

inose that have not taken the conservation measure. 


\section{LONG TERM RESOURCE PLANNING}

The thought process on the transition from the projects original Small Commercial Lighting Program to Local Government Involvement In Long Term Resource Planning For Community Energy Services, centered around the fact that the local utility (Tucson Electric Power) was trying to avoid bankruptcy. With this as there main focus, it became clear that the City could not have such a narrow small commercial focus and needed to work with the State Corporation Commission. In previous years of low-cost energy, many demand-side management (DSM) technologies simply were not cost effective. Today, however, with rising energy prices and the mandate to conserve, utility DSM programs and advanced energy-efficient technologies offer utilities significant opportunity for economic means to reduce operating costs and shift or defer load growth. Furthermore, recent developments in DSM technologies have improved energy quality and reduced customer maintenance costs.

It has been estimated that if electricity were used more efficiently with commercially available end-use technologies, $24 \%-44 \%$ of the nation's current demand for electricity could be eliminated. Almost all major electric utilities in the west are investigating such demand-side management (DSM) opportunities. In some service territories, for example, improved efficiency could soon produce as much power as that from new coal-fired plants (Table 3$)^{10}$ and produce it at a lower cost (Table 4) ${ }^{10}$. Even utilities that currently have excess capacity are finding that DSM offers an opportunity to build efficient end-use stock to help them meet their future load shape objectives.

'DSM Guidebook. Volume 2; Commercial Technologies, prepared by SERI (Solar Energy Research Institute) for Western Area Power Administration, 1627 Cole Boulevard, P.O. Box 3402, Golden, Colorado 80401.

${ }^{10}$ Planning for Stable Growth. Pacific Power and Utah Power Resource and Market Planning Program, Volume 1, Summary Report, 1989. 


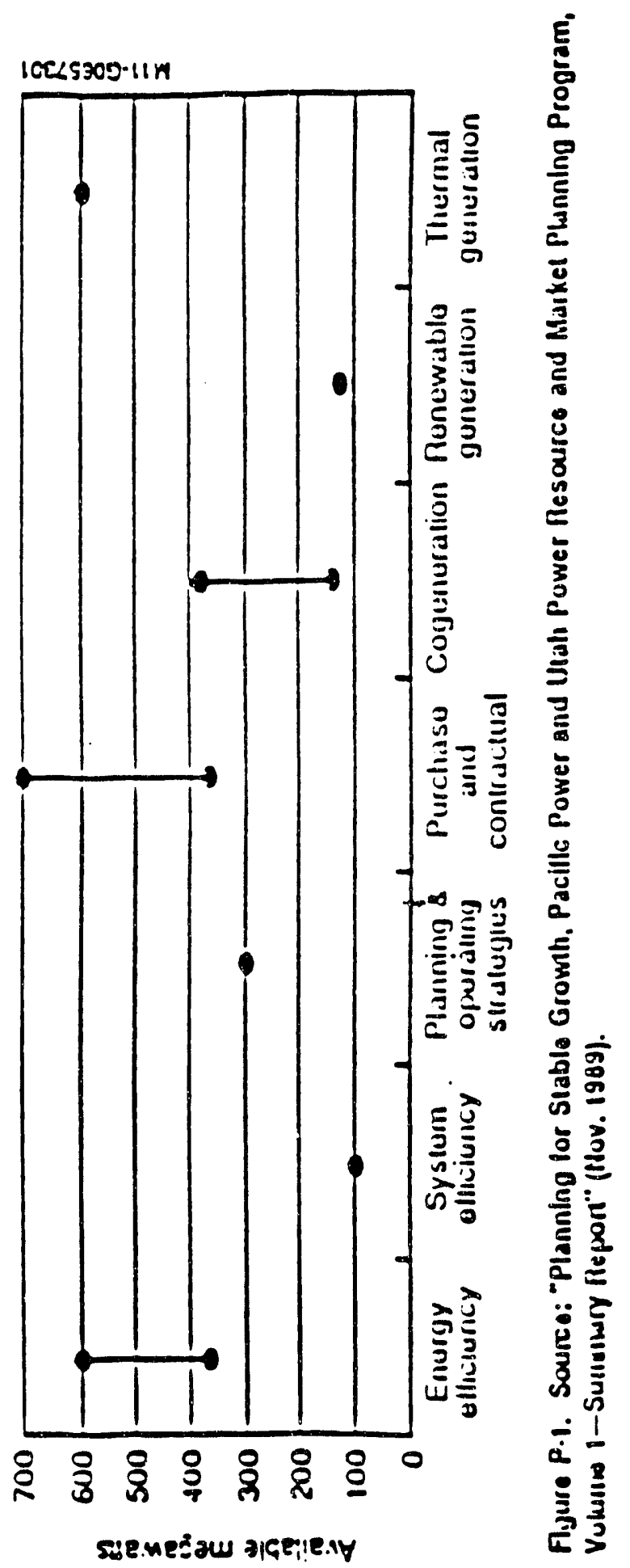


T.BBLE 4

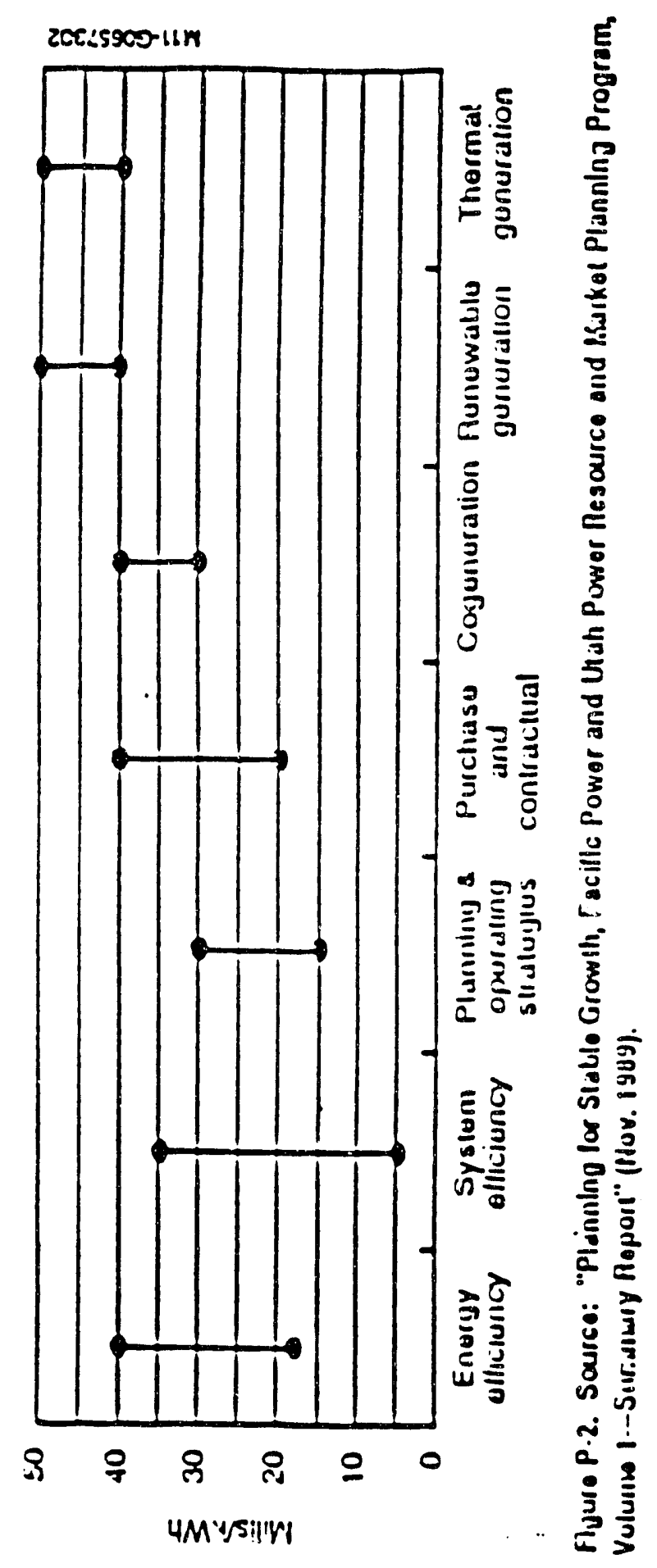


Utility DSM programs typically consist of several measures designed to modify the utility's load shape (for example, innovative rate structures, direct utility control of loads, promotion of energy-efficient technologies, and customer education). The coordinated implementation of such measures requires planning, analysis of options, engineering, marketing, monitoring, and other coordination activities, which ultimately directs you to a more compressive long term plan of state wide resource planning. 


\section{CHAPTER 3 - IVORKING WITH THE CHANGING UTILITY INDUSTRY}

\section{HISTORY}

In the 1980's many commissions learned that conservation is a realistic, low cost option to help meet the growing demand for electricity. In addition to low cost, however, there are many other reasons why commissions approved conservation programs.

For instance, just having a utility propose any conservation program was a major step and, particularly because the initial programs were small, commissions tended to approve programs the utility had proposed. After becoming convinced of conservation's worth, some commissions decided that any conservation measure that provided energy and power at a cost lower than the utility's avoided cost was acceptable. Thus, these commissions mandated that the utilities had to provide programs supporting all costeffective technologies for all customers. Other reasons for commission approval include satisfying Federal mandates, political or social benefits, research and development of conservation measures, and the creation of a market for proven conservation technologies.

These reasons are all important and sensible. However, with the large dollar amounts spent on conservation in today's programs, and considering the goal of trying to delay the need for future power plants, the state commission needs to focus on the primary reason for approving a utility's conservation program: its cost effectiveness!

\section{COMMERCIAL LIGHTING PROGRAMS RECEIVE MAJOR FOCUS}

As a practical matter, there is a limited amount of money to be spent on conservation. A commission could allow the programs to emphasize the social, political, and R\&D expenditures it has historically favored. However, if a commission wants to get the most value for a utility (and ratepayer) dollar spent on conservation, the commission should emphasize the cost-effectiveness of the expenditure. Using the analytic approach discussed above, the commission should (1) analyze the programs that the utility proposes to ensure they include only appropriate conservation measures, 
(2) calculate the benefit/cost ratio of each program, and (3) select those programs which offer the highest benefit/cost ratio.

This means that commissions should favor industrial and commercial programs over residential programs because they are more cost effective. Commissions should favor lighting programs over programs supporting motors, drives, appliances, and heating; ventilation; and air conditioning (HVAC) equipment because lighting is more cost effective. Commissions should favor programs which target geographic areas where the transmission and distribution losses are greatest because conservation installations there have the most value. Commissions should favor programs that require a customer contribution for installed conservation measures because the customer's contribution reduces the utility's cost to install measures. A commission which uses a total resource cost analysis must remember to include customer costs in the calculation of program costs to insure program benefit/cost ratio exceeas 1.00 . When prioritizing allocation of dollars to programs, however, the commission should use the utility cost only in the benefit/cost calculation to optimize the use of ratepayer dollars.

It may seem unfair to favor businesses, lighting products, or customers located in certain areas. This is no more unfair, however, than some neighborhoods absorbing the bulk of the environmental impacts of a power plant located therein while other neighborhoods get the benefits of the electricity produced by the plant. In fact, the process of selecting the best utility conservation program is comparable with selecting the best power plant option.

Interestingly, the result of focusing conservation programs on the most costeffective opportunities is that a greater number of ratepayers will be served. For example, by promoting a lighting program to commercial and industrial customers rather than a lighting, motor, and HVAC program, many customers receive lighting upgrades rather than just a few customers receiving lighting, motor, and HVAC upgrades.

There are two reasons why this result enhances the acceptance of conservation programs. First, since more customers receive the benefits of a conservation program, there are more supporters for the program. Especially since every customer has lights, every customer recognizes that they can participate and receive the benefits of 
conservation directly in their own facility. Second, when most facilities have had lighting upgrades and the most cost-effective lighting potential has been exhausted, there will be more ratepayer support for addressing cost-effective motor and HVAC programs if ratepayers had positive experiences with the lighting program.

\section{REGULATORY CHANGES}

The 1980s brought major changes in the relationship between regulators and regulated industries. On one hand, experiments with deregulation have created opportunities for the transportation and utility industries to sidestep regulatory oversight and to try their hand at "new" (or relatively new) business operations within the free market. On the other hand, regulators and legislators are becoming increasingly involved in overseeing and shaping certain utility activities.

The electric utility resource planning process provides a clear example of this growing evolution. A combination of economic and environmental imperatives have created strong regulatory and legislative interest in developing a truly integrated planning process that takes a broad view of the factors involved in serving societal energy needs. This approach has major implications for both the nature of utility planning and the resources required for implementation.

\section{LEAST-COST PLANNING}

Least-Cost Planning (LCP) is the process of selecting the mix of generation options, demand-side management measures, purchases, and sales that enable a utility to meet society's energy needs at the lowest overall cost subject to a variety of constraints, such as minimizing economic and environmental risks. Least-cost planners attempt to realize the potential available through efficiency improvements, load management and non-utility energy sources on equal footing with constructing new power plants.

In addition to environmental concerns, there are a variety of other reasons for using LCP. These include conditions of capacity surplus or capacity constraints, high rates and/or rapis rate increases in areas with previously low rates, such as in Tucson. The LCP approach itself is appealing to many because it provides a logical way to 
integrate load management and conservation into planning, ensuring that these resource options receive equal consideration when deciding how to provide electrical service. The LCP approach ensures that power plants will not be built when other options are cheaper. However, it does raise substantive issues such as how exactly to define what "cheaper" means, and whether or not "cheaper to whom"! For example, those utilities attempting to include fuel substitution options in their least-cost planning have discovered inconsistencies between the benefit-cost evaluations of fuel substitution and other DSM options. Resolving these issues will be part of the task faced by regulators, utilities, and local governments as they implement the LCP approach.

Today, regulatory agencies and utilities in 24 states are using least-cost planning; planners in another 18 states are in the process of implementing, developing, or considering least-cosi planning. Commissions enforce and encourage LCP through a variety of regulations and filing requirements, often using plant authorization or rate cases as the forum.

Development of a least-cost plan requires extensive amounts of data to characterize performance and impacts of various DSM options. Much of the needed data is not readily available. There is a particular need to leam more about energy end uses to aid in designing betuer programs, to predict technical potential, and to estimate program effectiveness for all sectors. Where data have not yet been specifically collected for an individual utility, planners use tools such as estimations from end-use models, engineering calculations, and field results obtained by other utilities.

\section{INCENTTVE MECHANISMS}

While DSM programs can be an effective and attractive element of a utility's resource plan, several direct financial disincentives exist that have slowed the adoption of energy-saving programs. Under some circumstances, a utility can ${ }^{11}$ :

"A Review of Utility Experience with Conservation and Load Management for Commercial and Industrial Customers, Steven Nadel, 1990, Washington, DC American Council for an Energy-Efficient Economy. 

- suffer lost short-term revenues when overall sales drop;
- experience under recovery of expenditures; or
- miss other opportunities for earning additional revenue.
- the possibility of adverse regulatory review with retroactive consequences;
a potential decrease in the utility's competitive strength if average rates rise;
the likelihood of additional sales losses due to independent customer conservation actions; and
increased liability risk incurred through increased involvement with customer premises or through product liabilities.

All of these conditions have led to an understandable reluctance on the part of many utilities to wholeheartedly enter into least-cost planning that fully and fairly considers DSM options. Consequently, financial incentives for DSM have become a topic of increasing regulatory importance nationwide.

The incentive proposals take many forms. Some tie a DSM incentive to estimates of avoided supply-side costs. Others follow a more traditional rate of return on rate base formula. Still others attempt more radical changes in the overall rate making procedures by providing incentives to reduce sales via any means, thereby discouraging growth in energy sales.

In order tn overcome the inadvertent disincentives embodied in current regulation, proposed incentive mechanisms must:

- allow for timely recovery of expenses

- allow for recovery of net lost revenues

- provide a positive retum above cost to compensate for risk.

Balancing accounts eliminates under- or over-collection problems for DSM expenditures over a multi year period, with interest. Lost revenue adjustments protect utilities from net revenue losses attributable to the successful pursuit of DSM programs. Bonuses provide for reserves in excess of direct costs. In addition, the mechanism should ensure that no new disincentives are added through the adoption of procedures to collect the incentive. 
Overall, six states currently have comprehensive incentive mechanisms (direct program cost recovery, lost revenues, and a bonus) in place for at least some utilities. Eighteen more states have at least one of the necessary incentive mechanisms elements available.

The interest with which utilities around the country have participated in several recent collaborative processes shows the importance of establishing appropriate regulatory incentives for DSM. Offering DSM programs will become an "all-win" situation for utility management, shareholders and customers. A change incorporate culture away from the "sales growth" mentality may even evolve as managers realize that DSM programs offer the best opportunities to maximize rate of return.

\section{DSM POTENTIAL}

The 1980s unleased a flood of ever more powerful and cost-effective electrical devices. The total electricity-saving potential has about doubled in the past five years, yet its unit cost has fallen by about two thirds. If anything, this progress seems to be accelerating as new developments in materials, microelectronics, power electronics, computer design, and manufacturing.

Agreement is growing that a surprisingly large amount of electricity--far more than the $5 \%$ to $15 \%$ often cited a few years ago-could be saved if all of today's best available technologies were fully applied. EPRI in 1990 estimated a long-term saving potential of about $25 \%$ to $50 \%$ (of which some is rather expensive) in addition to the $15 \%$ that is already included in utilities' demand forecasts or efficiency program plans.

EPRIs assessment found ${ }^{12}$ :

In the residential sector, between $27 \%$ and $46 \%$ of the electricity forecast to be needed in the year 2000 could be saved. That amounts to between

${ }^{12}$ Utility Energy Strategies: The Role of Efficiency. Productivity and Conservation. CU-6272, EPRI (Electric Power Research Institute) 3412 Hillview Avenue, P.O. Box 10412, Palo Alto, CA 94303. 
289 and 484 billion $\mathrm{kWh}$. The biggest contributors to this savings potential are anticipated technological advances in water heating, space heating and lighting technologies.

- In the commercial sector, between $23 \%$ and $49 \%$ of the electricity forecast to be needed in the year 2000 could be saved, amounting to between 234 and 505 billion $\mathrm{kWh}$. The biggest contributors to this potential savings are lighting, space cooling and miscellaneous loads, such as office equipment, computers and copy machines.

- In the industrial sector, between $24 \%$ and $38 \%$ of forecast to be used in the year 2000 could be saved, equivalent to between 277 and 447 billion $\mathrm{kWh}$. The biggest opportunity for improvement lies in motor drives, which make up $67 \%$ of industrial electricity used today.

\section{IMPLEMENTATION OPTIONS}

There are several ways a commission can allocate its utilities conservation budget funds and still maintain the principle of least cost planning. First, the entire budget could be devoted to the most cost effective program(s). Second, rebate levels could be established such that each measure has the same benefit/cost ratio. For example, some retrofit lighting measures might get rebates worth $75 \%$ of their installed cost while a retrofit motor might only get a rebate worth $25 \%$ of its installed cost. Third, applicable to retrofit programs only, all customers could receive bid packages at regular intervais stipulating the maximum rebates eligible for each measure (comparable to the avoided cost), up to the full installation price. Any customer could then bid its project rebate at an amount up to the maximum rebate eligible. The utility would then select the projects with the best benefit/cost ratios until it exhausted its budget for the selected period.

In conclusion, the conservation resource should be analyzed financially according to the same least cost planning approach used in evaluating power plants. Conservation resources should be deployed at the least cost for the most benefit. The benefit/cost ratio analysis provides a commission with the tool it needs to make this assessment. Since capital is the scarcest resource, it behooves a commission to ensure that the ratepayers' 
dollars provide the most conservation benefits possible. This approach also results in the greatest number of ratepayers served by conservation programs, thus enhancing the acceptance of conservation by ratepayers.

\section{TUCSON ELECTRIC POWER PILOT COMMERCIAL AND INDUSTRIAL LIGHTING EFFICIENCY PROGRAM}

\section{Background}

In the Resource Planning Order, Decision No. 57589, Tucson Electric Power was directed to implement an on-going demand side management program including conservation lighting. In the Rate Settlement Agreement, Decision No. 57586, the Commission authorized the establishment of a $\$ 1$ million annual conservation and energy efficiency fund for the years 1991, 1992, and 1993. This fund will be used to promote conservation and energy efficiency in TEP's service area. In compliance with these decisions, TEP's initial conservation program is the Commercial and Industrial Lighting Efficiency Program.

\section{Program Goal}

The objective of TEP's Pilot Retrofit Commercial and Industrial Lighting Efficiency Program is to reduce peak demand and promote energy conservation. The goal for TEP's pilot program is to achieve a $4445-\mathrm{kW}$ reduction in total direct and indirect lighting demand by the completion of the pilot program in 1993.

\section{Qualifying Lighting Technologies}

In addition to specular reflectors, TEP's pilot program will include all types of lighting modifications, techniques and devices which utilize energy-efficient technology, and exceed minimum Federal standards. The program will include incentive rebates for occupancy sensors and controls as well as provisions for day lighting. Rebates are restricted to indoor lighting systems of Commercial and Industrial customers of TEP. Program Cost Benefit Analysis

The Settlement Agreement contained in Decision 57586 includes a provision for the establishment of a Conservation and Energy Efficiency Fund by TEP for each of 
three years (1991, 1992, and 1993), \$1 million will be entered into the fund. The fund will be debited for all the costs associated with TEP's conservation programs. These costs include administrative costs, monitoring and evaluation costs, and incentives granted to customers. Since the conversion of existing lighting systems to more efficient components is one of the easiest and least expensive conservation measures that a business could consider, a large portion of the fund will be used for this purpose. An estimated $47 \%(\$ 1,400,000)$ of the $\$ 3$ million fund will be allocated to lighting. Approximately $70 \%$ of that amount will be allocated to incentive rebates and approximately $21 \%$ allocated for administrative costs. The remaining $9 \%$ will be used to cover educational and promotional costs.

THE ENTIRE PLAN CAN BE REVIEWED IN APPENDIX $\underline{B}$ 


\section{CHAPTER 4 - LESSONS LEARNED}

\section{FUTURE RATE DESIGN}

As part of this study, an ad hoc committee was formed to look at Tucson Electric Power Company rate design. A review of residential prices during the 1980's found Tucson Electric Power's rates to be considerably below those found in most of 13 cities studied. A second finding was that electric bills for TEP's residential customers rose much slower than consumer prices in general during the decade. Finally, it was concluded that consumer incomes had risen stifficiently so that increased electric rates would not place an unbearable burden on Tucson's residential customers.

The Company had no increase of any kind for the period 1984-1988. More recently, a base rate increase of $11.9 \%$ was granted in October of 1989 . In addition, two temporary fuel surcharges were granted: 3\% in December of 1990 and 5\% in March of 1991. Both of these temporary surcharges expired with the implementation of $15 \%$ base rate increase in October of 1991 . Table $5^{13}$ provides a chronological history of TEP rate increases/decreases for the period 1976 to present.

As higher rates are implemented, it becomes increasingly important to examine the effect of those increases on Tucson's competitiveness within an economic development context. It is critical that electricity costs faced by businesses remain comparable to Tucson's "competition", so that new companies are not discouraged from locating to Tucson, It is not necessary to have the lowest costs among cities with which Tucson competes. Rather, one only needs to guard that costs don't differ too much so as to make power costs an issue. Secondly, it is imperative that existing companies not be encouraged to either relocate outside of Tucson or to leave the system because they can generate their own power at a lower cost.

${ }^{13}$ Electric Rates and Company Comparisons. Tucson Electric Power Company, 4350 East Irvington Road, P.O. Box 711, Tucson, AZ 85702. 
Tucson Electric Power Company
Rate Summary

\begin{tabular}{|c|c|c|}
\hline $\begin{array}{l}\text { Month } \\
\text { Effes:ive } \\
\end{array}$ & Type of Change & $\begin{array}{c}\% \\
\text { Grarted }\end{array}$ \\
\hline $\begin{array}{l}\text { January } 1976 \\
\text { May }\end{array}$ & $\begin{array}{l}\text { Ne'n Mexico Generation Tar } \\
\text { Gene:al Rate Increase }\end{array}$ & $\begin{array}{r}0.3 \\
12.0\end{array}$ \\
\hline $\begin{array}{l}\text { Ocioce: } \\
\text { Novenice: } \\
\end{array}$ & $\begin{array}{l}\text { Fue! Adjusinent Deciease } \\
\text { Fue! Adjusinent Dec:ease }\end{array}$ & $\begin{array}{l}-2.9 \\
-3.5 \\
\end{array}$ \\
\hline $\begin{array}{l}\text { April } 1977 \\
\text { Juiy } \\
\text { Co:obe: } \\
\text { Novemcer: } \\
\end{array}$ & $\begin{array}{l}\text { Fue! Adjustment Inc:ease } \\
\text { Fue! Adjustment Inc:ease } \\
\text { Fue! Adjustnent Increase } \\
\text { Fue! Adiustment Deciease }\end{array}$ & $\begin{array}{r}5.6 \\
2.5 \\
2.7 \\
-2.1 \\
\end{array}$ \\
\hline $\begin{array}{l}\text { Marsi } 1973 \\
\text { June } \\
\text { Noverioe: } \\
\end{array}$ & $\begin{array}{l}\text { Fue! Adjusinent Decrease } \\
\text { Fue! Adjusinent Dec:ease } \\
\text { Fue! Adjusiment Inc:ease }\end{array}$ & $\begin{array}{r}-1.4 \\
-0.3 \\
1.4 \\
\end{array}$ \\
\hline $\begin{array}{l}\text { May } 1979 \\
\text { Jure }\end{array}$ & $\begin{array}{l}\text { Ne'w Mexico Tax Eiiminated } \\
\text { Fue! Adiusiment Incieass }\end{array}$ & $\begin{array}{r}-0.3 \\
7.3 \\
\end{array}$ \\
\hline Massi 1980 & Gene.בl Rate Increase & $i .5$ \\
\hline $\begin{array}{l}\text { Jasuar: :985 } \\
\text { Miay } \\
\text { Wiay }\end{array}$ & 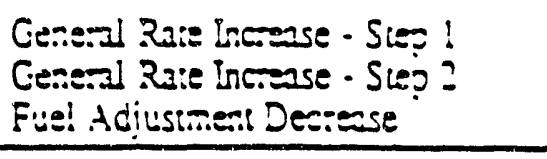 & $\begin{array}{r}9.5 \\
6.9 \\
-. .7 \\
\end{array}$ \\
\hline Ccoode: 1983 & $\begin{array}{l}\text { Ë:enjue } 10 / 95 \text { inel cosi } \\
\text { inc:ense rolled into base } \\
\text { ries xe: ACC }\end{array}$ & 4.4 \\
\hline $198:-1988$ & No changes & \\
\hline July 1989 & $\begin{array}{l}\text { Temporsy surcharge through } \\
\text { Oc:ove: is }\end{array}$ & 3.0 \\
\hline $\begin{array}{l}\text { Ocrobe: } \\
\text { Cr:oce: }\end{array}$ & $\begin{array}{l}\text { End of iemporay surcharge } \\
\text { Gene. Il Ra: Increase }\end{array}$ & $\begin{array}{r}-3.0 \\
11.9 \\
\end{array}$ \\
\hline Decsmide: !990 & $\begin{array}{l}\text { Temporary surciarase ef:ecojve } \\
D=0.90\end{array}$ & 3.0 \\
\hline Maris! !C9! & Temporay surcharse & 5.0 \\
\hline Ocrobe: 1991 & $\begin{array}{l}\text { Gene:al Rate Increase } \\
\text { End of tempory surcharge } 19 / 90 \\
\text { End of iemporyy surcharge } 319 !\end{array}$ & $\begin{array}{l}15.0 \\
.3 .0 \\
-5.0\end{array}$ \\
\hline
\end{tabular}


Tucson links to other metro areas, in an economic development context, in two different ways. First, Tucson competes with other cities for companies looking to relocate or to expand. According to members of Tucson's economic development community, cities in this category are Salt Lake City, Las Vegas, Albuquerque, Denver, and El Paso. For this group, electric rates are an important cost factor for potential firms: rates that are too high, relative to the "competition" may be the deciding item in a long list of factors considered by firms.

A second group is comprised of those cities from which local economic development agencies actively recruit firms. These areas include Los Angeles, New York City, New Jersey (represented by Newark), Chicago, and San Francisco. It is important when approaching firms in these large cities to show that Tucson provides a lower-cost environment, and electricity costs are often an important component of those costs. A third grouping, consisting of Phoenix, San Diego and Dallas also were included in the study because of their regional significance. Utility companies and the metro areas they serve, which were selected for this study, are shown in Table 6.

Average Price Comparisons

Data for one year period that ended in June 1991 is used to compare electric rates in selected cities. Data for an entire year is used rather than for the most recent quarter since some but not all companies have adopted seasonal rate structures. The $n$ ta for all companies except Salt River Project are from the Edison Electric Institute ${ }^{14}$. Data for SRP, which is not investor-owned and therefore not included in the Edison Electric reports, where provided by SRP. These data were the most recent available and do reflect increases in Tucson Electric rates approved in October of 1991. Tables 7-10

14 Typical Residential, Commercial And Industrial Bills: Investor-Owned Utilities. July 1, 1991, Published by Rate Regulation Department, Edison Electric Institute. 


\section{Metropolitan Areas and Associnted Companies}

\begin{tabular}{|c|c|}
\hline $\begin{array}{l}\text { Albuquerque } \\
\text { Cuscago } \\
\text { Dallas } \\
\text { Deaver } \\
\text { El Paso } \\
\text { Las Vegas } \\
\text { Los Angeles } \\
\text { New Yori City } \\
\text { Newark, NU } \\
\text { Phoenix } \\
\text { Salt Luke City } \\
\text { San Dieģo } \\
\text { San Fraciseo } \\
\text { Iueson }\end{array}$ & 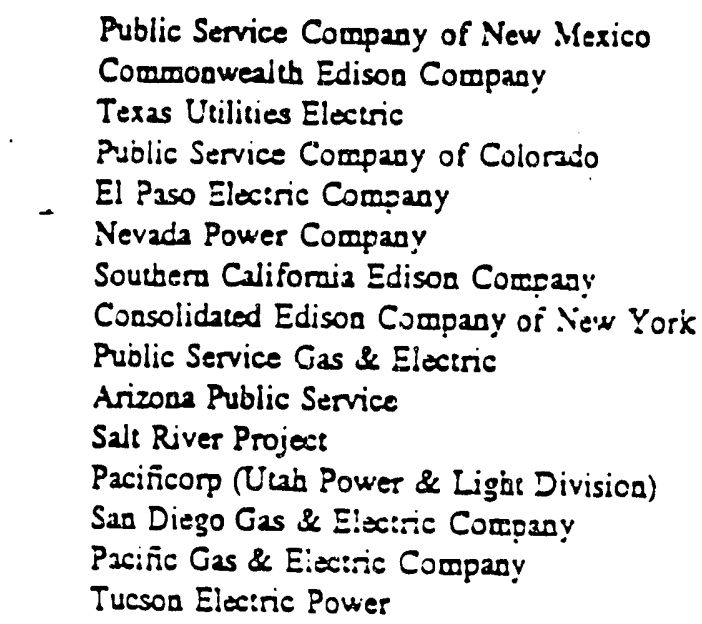 \\
\hline
\end{tabular}



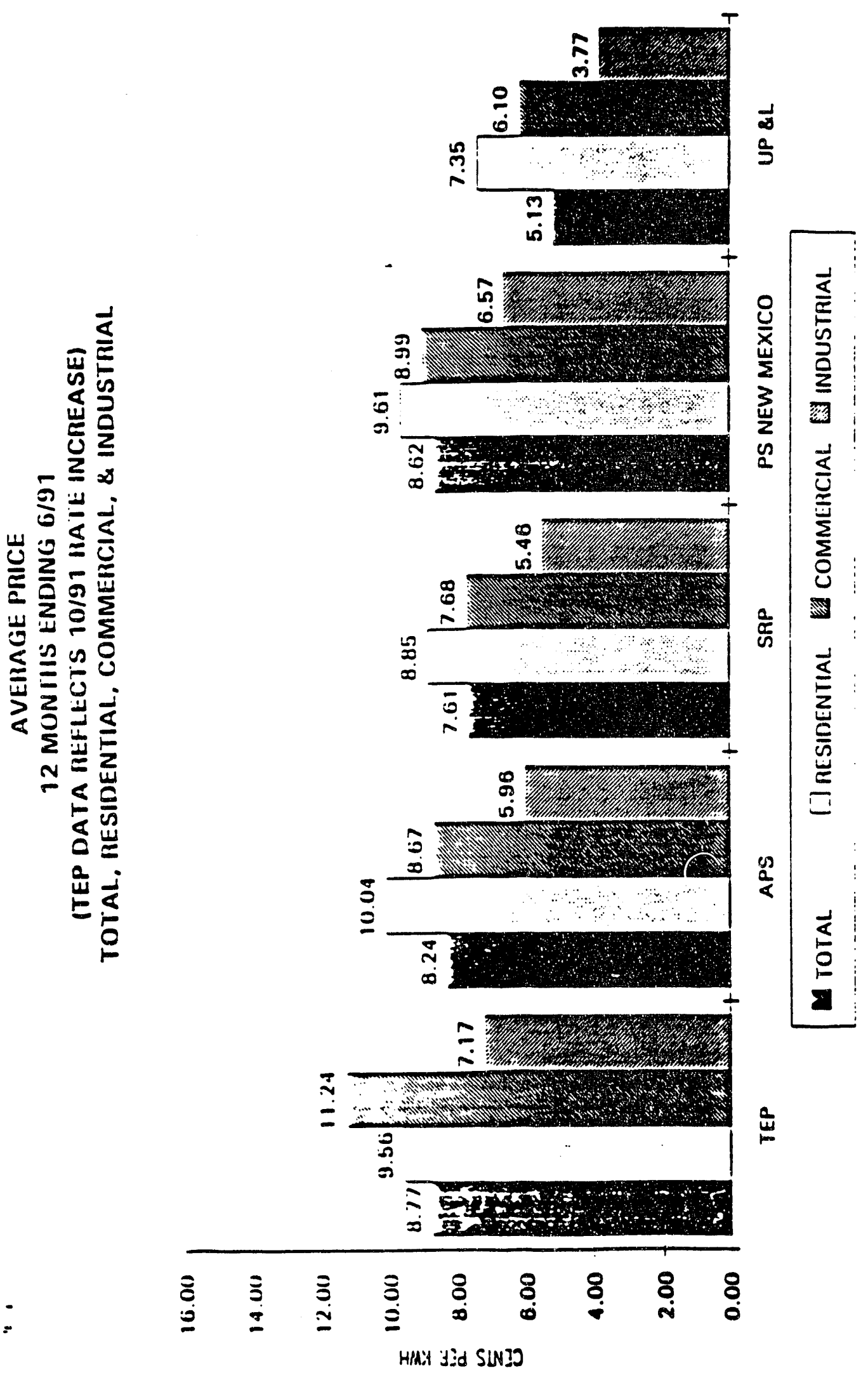
TABLE 8
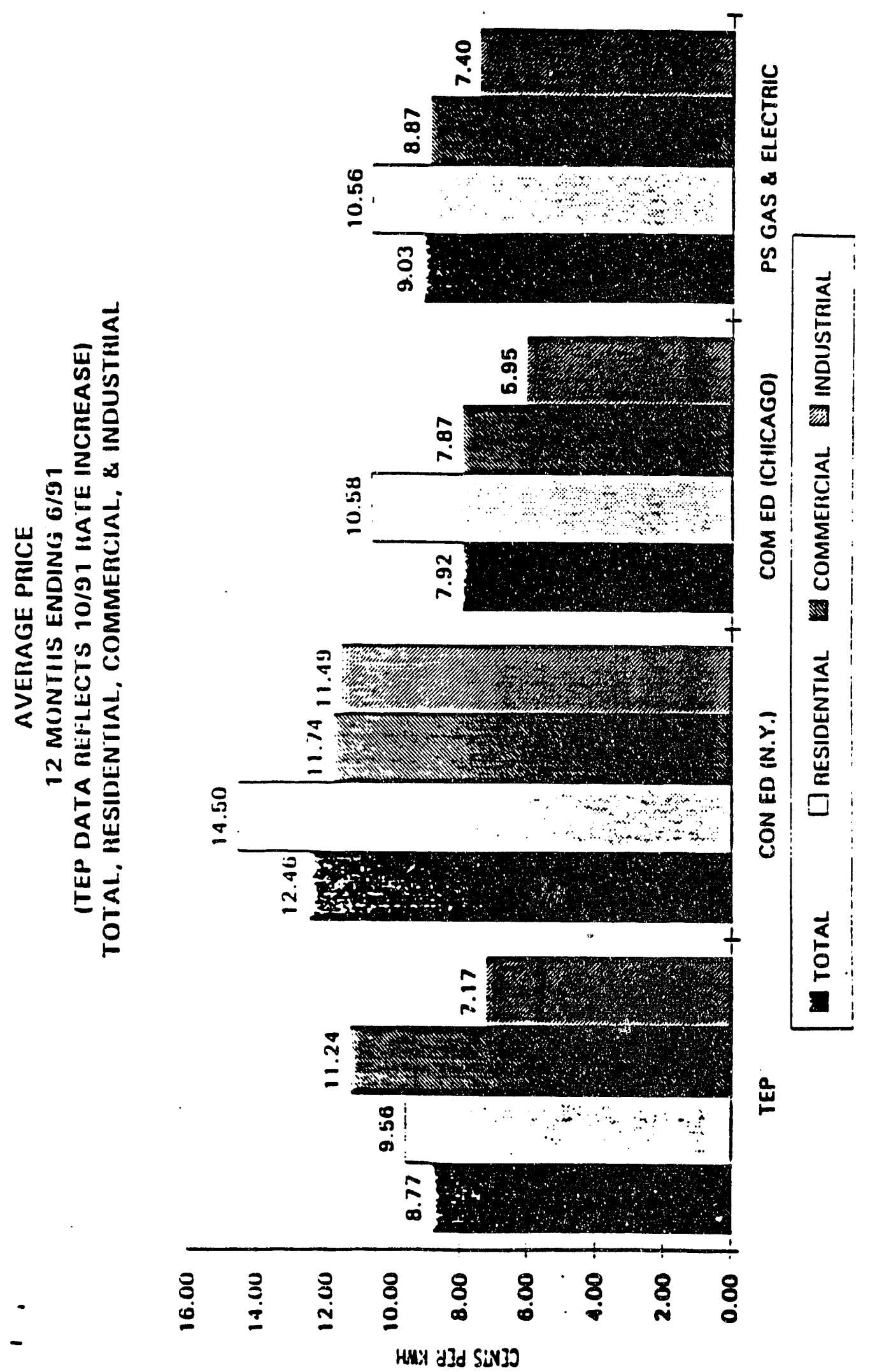

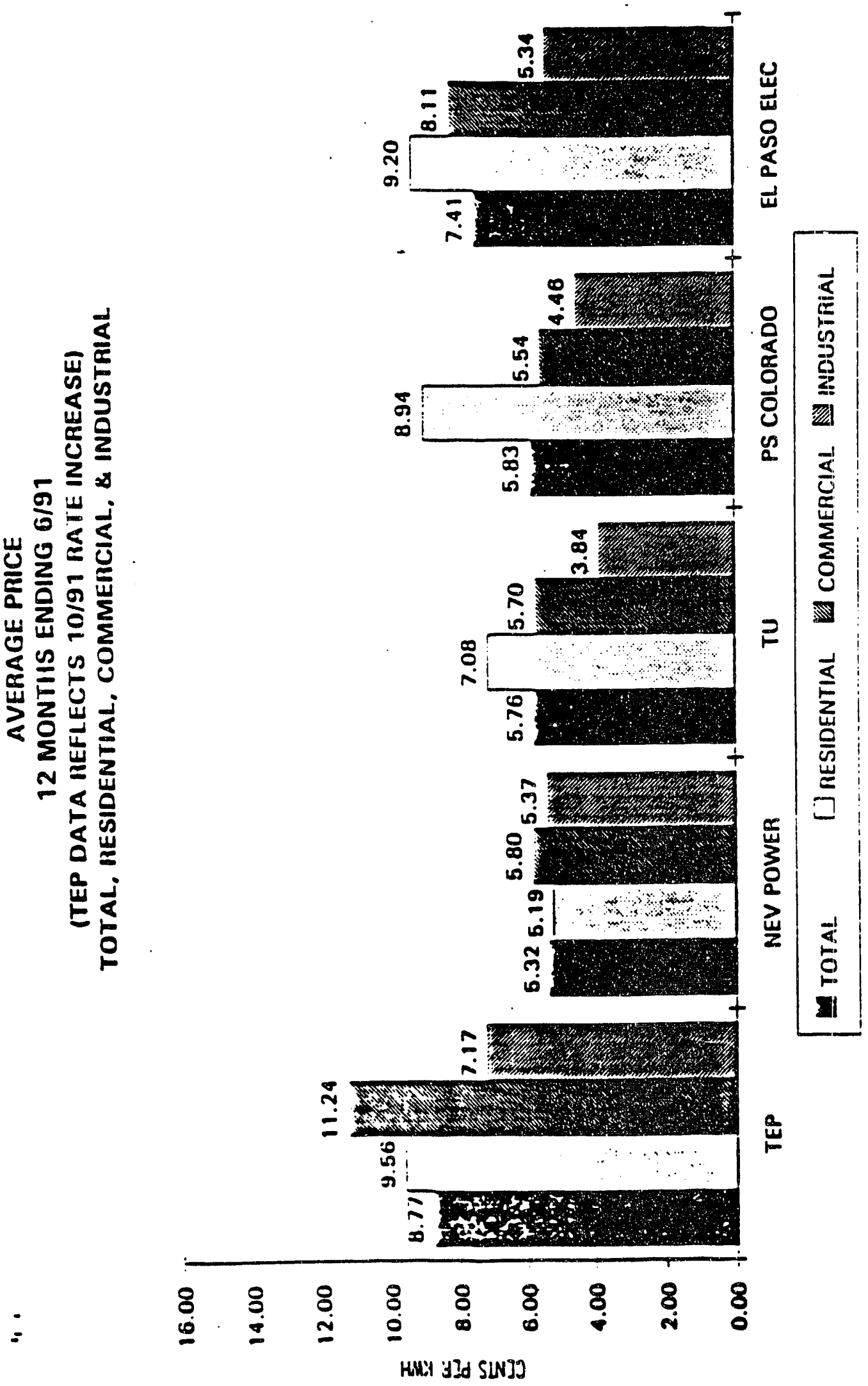
TABLE 10
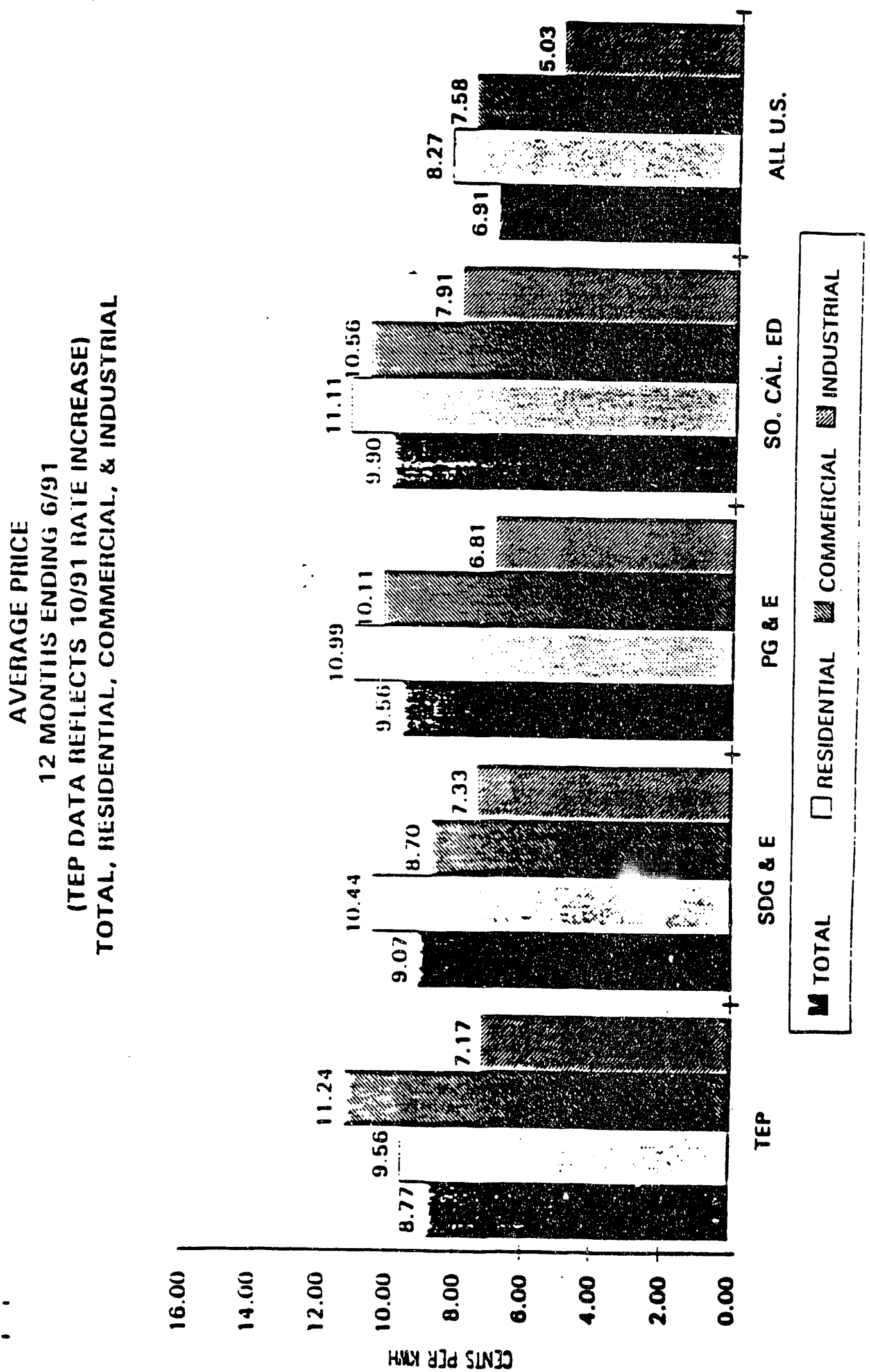
preseni the average price ${ }^{15}$ for residential, commercial and industrial customers as well as for total customer retail sales (i.e., aggregated across all customer classes).

\section{Electricity Costs and the Business Climate}

How important are electricity costs to business firms? Which industries are greatly affected by rate increases and which industries are affected little? In an effort to answer these questions, data from national input-output tables are analyze $\iota$ : interindustry purchases are combined with a 78 -sector output matrix representing data for calendar year $1990^{16}$. Purchases of electricity as a percent of output by industrial sector are presented in Table 11. Industries near the top of the table would be expected to be more sensitive to electricity costs when considering location decisions or generating their own power.

The importance of electricity costs varies considerably across in:dustries. Pipelines (SIC 46) use the most electricity relative to the value of its ouiput, $14.2 \%$. Electricity costs comprise a large portion of operating costs for mining cperations, steel mills, foundries and smeling operations. Other manufacturers :ith purchases exceeding $1 \%$ of the value of their output include paper, chemicais, plastics, textiles and rubber products. Examples of large manufacturers in the Tucson area include Hughes Aircraft (aerospace, 0.8\%), McCulloch Corporation (metalwcrki z. 0.9\%), AiRejearch (instruments, 0.6\%), IBM (computers, $0.4 \%$ ), and wockheed Aeromod (other transportation equipment, $0.4 \%$ ).

Interestingly, several local-serving industries use large amounts of electricity relative to tile value of their output, including federal, state \& local government

'The average "price" is calculated as total dollar revenues divided by total saies in kilowatt-hours. The resulting price is expressed in cents per Kwh. The revenue data includes the revenue billed for the amount of kilowatt-hours sold, revenue from state and local taxes, energy or demand charges, consumer service charges, environmental service charges, franchise foes, fue! adjus!ments, and other miscellaneous charges. Price differs from the term "rate" as price refers to the average of severil rate schedules used for various customer classes, as well as any "add-on" charges such as taxes.

${ }^{10}$ Lata was provided from several sources including the Annual Survey of Manufacturers, Mineral Staustics, and Agriculture Statistics. 
Electricity Purchases as a Percent of Output by Sector, 1990

Sector

Pipeline

Iron Ore Mining

Fed.. Sute \& Loeal Gov. Enkerprises

Nonmearilic Mining

Other Nonierrous Mesis

Noniersous Mining

Ferrous Metsis

Hoced. Repairs Ereept Autos

Sione. Cay \& Giess

Reoil Trade

Nesural isa Emraction

Phper

Obre: Chemieals

Agricutural Fercilizess

C.sude Peroicum

Plastic Produc's

Exing \& Driricing Places

Coal Mining

Medisise. Educroion, Non Prouit Ors.

Movies \& Amusenters

Texitite. Excluding Knits

Revioer Produces

Kaiting

Misc. Nonelessial Macisinery

Meal Produces

Cunstrucion, Mining, Oilleid Equigmen:

Mesiworicing Mectinety

Elece bidustria Apparzos \& Distro. Eq. bumber

Wuar as Saniestion

Engnes \& Turbite

Howeetrid Ainplinnces

Electrial Lighting \& Wiring Equipmert

Agricubure. Forewy \& Fisnery

Sf xill lodusary Mactinery

\section{Copper}

Wrokenale Trade

Acosspece

Real Esule

Werer Traspor

Funimive

Stups. Bouks

Commanicatioa Equipment. Eectronte

Mive. Manufacoures

Frasece \& Insurnace

Aprosatural Mechioesy

Pratiag \& Publiening

Aveonebile Repars

Paroleum Refiause

Inerventes

Appard. Housebold Terriles
Related SIC Codea

*

46

101.106

14.2

-

$1+1-1+5.2+7.148 \mathrm{p} .1+9$

7.3

6.7

$+.0$

333×2331.335xi351.336x2362.3263 3.7

10:-i05.108p.109 $\quad 3.6$

$331-332.339 .3+62 \quad 3.6$

70p. $76:-769 \% \mathrm{p} \quad 3.0$

$32 \quad 0.7$

52-57.59.7396.304: $\quad 3.1$

$131 p .1390 .138 p \quad 1.3$

$26 \quad 1.7$

$991-396.939 \quad 1.7$

397

131;.:39-3.138p 1.6

$307 \quad 1.5$

$58.700 \quad 1.5$

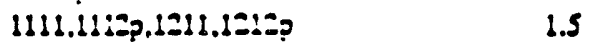

30x3012.52-84.36.39=2 $\quad 1.5$

78.79 l.t

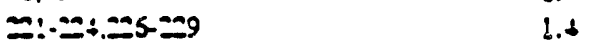

$301-305.306 \quad 1.3$

ams 1.0

$353 \div 7.356 .359 \quad 0.9$

3a 0.9

$3951.3 \quad 0.9$

$35+10.9$

361.96:-39:

It 0.9

\$9?p.\$9+197 0.9

उ51 0.9

3630.9

$36+369 \quad 0.3$

$01.05 .07,08.09 \quad 0.5$

3550.3

3331.3340 .3351 .33620 .3

So.st 0.3

ग. 0.3

65-66.:S31p 0.3

H 0.7

300.8

3 3.3 0.8

$366.367 \quad 0.7$

3900

$60-6+67.0 .5$

נS: 0.0

$\begin{array}{lll}3 & 0.0\end{array}$

$75 \quad 0.6$

$39 \quad 0.6$

38xes 0.6

30.6 


\section{Electricity Purchases as a Percent of Output by Sector, 1990}

\section{Sector}

Service Indusary Machinery

Food \& Toinaceo

Shoes \& Leachex

Communiestion Services

Trueking, Highway Passenge: Transit

Mowr Venicies

Compuers

Other Trasporation Equipmest

Busineas Services

Raiirosd

Transporation Services

TV Sas, Radio. Phonograpins

Cuter Oftuce Equipmes:

Ges Cliiitios

Air Tiznsoor

Cunstrusion
Reisled SIC Codes $\%$

$358 \quad 0.5$

$20.21 \quad 0.5$

$31 \quad 0.5$

48.0 .5

41.420 .5

3710.4

35.7.35it 0.4

374.275 .3790 .4

$73 \times 7396.7692-1.7699 \mathrm{p} \quad 0.3$

10.4740 .3

$47 x+740.3$

3650.3

357.35 .76 .3579

49:.49:0 0.2

45 $0 .=$

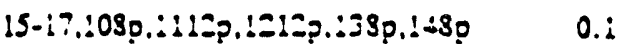

Noces and wobreviacions:

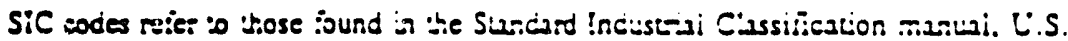

Defarssend of Luoor.

"po means par

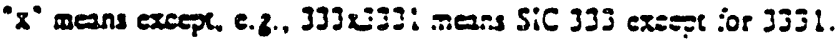

Source: WEFA. lac. 
enterprises $(6.7 \%)$, hotels $(3.0 \%)$, retail trade $(2.1 \%)$, eating \& drinking places $(1.6 \%)$, medicine, education \& non-profit organizations (1.5\%), and movies and amusements $(1.4 \%)$. For these industries, the location decision is not applicable but generating their own electricity may be an option for certain large users.

A city's business climate and its attractiveness to relocating or expanding firms involves more than electricity costs, of course. Other cost factors include, but are not limited to, the costs of labor, capital, raw materials, transportation costs and local taxes. Additional related factors include the degree of unionization, productivity of workers, man-hours lost to strikes, and such government controlled factors as unemployment compensation payments and environmental controls. Additional factors that are important in the business location decision include the "quality of life" of an area. Measures such as expenditures on education and health care, and quality of transportation services are often included in studies of business climate ${ }^{17}$.

A survey by Fortune magazine of the 500 largest manufacturing firms asked executives to rank factors which had influenced actual location decisions during the past five years ${ }^{18}$. Thirty-eight percent of the companies identified "productivity of workers," making it the most important factor. In order, other factors cited were proximity to customers, efficient transportation facilities, availability of unskilled or semi-skilled workers, community receptivity to business, and business taxes. Availability of skilled workers, proximity to raw materials/supplies, availability of energy supplies, and a growing regional market rounded out the top 10 factors. Interestingly, the study reports on the availability, not the cost, of energy, but it's important that energy was one of the top ten items of concem, and was mentioned by $21 \%$ of the respondents.

The Fortune survey also found that for the relocation of corporate headquarters, the most important factor was the "quality of life for employees" followed by "personal

\footnotetext{
${ }^{17}$ Data supplied by Tucson Electric Power using a study by Grant Thomton. Rankings are based on 23 factors thought to influence the location decision of manufacturing firms.
}

${ }^{18}$ Why Corporate America Moves Where. Fortune, New York, N.Y. 1982. 
preferences of executives" and "proximity to other facilities". A study by the Conference Board of requirements for the location of research \& development facilities found the top five factors to be: near headquarters, scientific/technical personnel, quality of life, near manufacturing, and near university or research center. Neither study identified energy or electricity costs as an important factor.

There are many business climate factors that enter into the location decision process. Electricity costs are only one component of total costs faced by a firm. For most firms, labor, capital and transportation costs will be far larger than electricity costs. But that does not mean that the latter are unimportant. For a firm that faces similar costs for labor, capital, and transportation, electricity costs may be the determining factor in a firm's location decision. And for some firms, like copper mines, electricity accounts for a large portion of total costs.

Local firms who sell their products in a global market may be unable to pass along the cost of electricity to their customers in their pricing. Other firms serving the local market, like retailers, will pass these costs aiong to local consumers. Governmental agencies, of course, will pass along these costs to taxpayers.

Prices of commercial and industrial power in Tucson may have risen to a point that affects Tucson's ability to attract and to retain business firms. Prices at TEP for commercial and industrial users today are significantly higher than prices found in those cities with which Tucson competes for new firms. This could raise a red flag in recruitment efforts of certain firms for which electricity costs are an important factor. It's not necessary for Tucson to have the lowest electric rates among the cities with which it competes. It is important that electricity costs don't deviate too widely from the norm.

The feeling is that Tucson's residential consumers currently are paying too little, which results in higher prices for businesses. The price faced by commercial customers is very high, rivaling and surpassing the price found in many of the cities from which Tucson actively recruits. Also, TEP's industrial price is significantly higher than offered in cities with which it competes for new firms. Residential customers, meanwhile, enjoy prices that are considerably below average. 


\section{FUTURE PROGRAMS AND RESEARCH}

In one indicator of how much rebate and other demand-side incentive programs are becoming long-term features of utility behavior, the Department of Energy has added questions about demand side programs to its annual survey of about 500 of the largest electric utilities in the country. Data from 1990, the first year which gave good information, was published late last year, along with the utilities' predictions for future program growth. DOE says that between 1990 and 2000, utility expenditures on DSM will go up an average of almost 10 percent a year, and both kilowatt hour savings and kilowatts removed from peak load by conservation will increase an average 17 percent a year. The DOE survey shows that in 1989 , demand-side measures cut 13,000 megawatts from peak load nationally, and about 5,000 megawatts of that was by conservation, with the rest attributable to direct load control and interruptible load. In 1990 , that grew to 17,000 megawatts that had been cut, of which 6,000 megawatts were from conservation. 6,000 megawatts is the capacity of about 120 peaking plants. Total energy savings were about 15 billion kilowatt hours in 1989 and 17 billion $\mathrm{kWh}$ in 1990 , and expenditures, were $\$ 40$ million in 1989 and $\$ 1.2$ billion in $1990^{19}$. If you apply the DOE escalation percentages to those 1990 numbers, the picture you get of the year 2000 shows utilities spending $\$ 3.3$ billion a year on demand-side management, and cumulative spending for the decade of $\$ 23$ billion on DSM. The result: conservation alone cuts 39,000 megawatts--that's about 78 peaking generators--from peak demand.

The Electric Power Research Institute, or EPRI, which is run by the utilities, estimates programs will be even larger-that a total of $\$ 30$ billion will be spent during the nineties to eliminate 45,000 megawatts of load ${ }^{20}$.

${ }^{19}$ Energy Casebook. U.S. Department of Energy, Western Area Power Administration, Phoenix Area Office, P.0. Box 6457, Phoenix, AZ 85005.

${ }^{20}$ DSM Customer Response, Volume 1: Residential and Commercial Reference Load Shapes and DSM Impacts, EM-5767, EPRI, 3412 Hillview Avenue, P.O. Box 10412, Palo Alto, CA 94303. 
This brings up another interesting aspect of the demand-side management business, what if that investment doesn't pan out? If ratepayers don't get the capacity they're paying for, so they have to pay to build expensive new powerplants on top of picking up the tab for all the ineffective DSM. Of course, measures are going into place to help ensure that utilities are penalized if their programs don't work, to help balance out the risks and rewards. But one of the biggest question marks hanging over the future of DSM is, what's going to happen when people's rates start going up because of it? It's not easy to predict what that opinion will be, whether people will agree with the argument that buying new light bulbs for some office building across town is worth paying higher electric rates, and in fact is cheaper than building a new generating station. Regardless of the ultimate truth of the philosophies behind DSM, public psychology is difficult to predict, and it's an important wild card when you're trying to make any longterm predictions about the future of DSM. All legislators and many regulators are elected officials, and if public opinion turns against DSM for any reason, they're likely to turn their backs on these programs much more quickly and decisively that they came to support them over the last few years. In the present regulatory and legislative environment, debate has pretty we'l ceased over whether or not rebate programs are a good thing, and the activity has focused on how they should be structured. People seem to agree that the first order of business is to get the utilities behind the program, and the best way to do that is to follow a time-honored tradition and use financial incentives that vary in amount depending on what state you're in. Since utilities traditionally made more money the more units of electricity they sold, they are not too enthusiastic about having regulators tell them to reduce their sales. So the state commissions have been at work devising incentives that reward utilities for implementing successful programs and, hopefully, penalize them if the programs don't work.

Obviously, a key element here is the ability to assess how effective a utility's demand-side investments are in gaining the load reductions that they're supposed to achieve. Most observers of the demand-side scene today agree that measuring and monitoring is the largest obstacle that has to be tackled before rebate programs can grow to the levels that people are predicting. Once evaluation methods are perfected, you 
might see even more DSM, because it may be even more successful than people realize. Industry consultants are predicting utilities will end up spending 5 to 10 percent of their DSM budgets on monitoring and evaluation alone ${ }^{21}$. If that's true, and if even the fairly conservative DOE numbers about total DSM expenditures are correct, you're looking at anywhere from one to three billion dollars being spent on those products just as a result of these programs.

Finally, virtually everyone in this business agrees that a major trend on the horizon is DSM for gas utilities. While activity is hot in electricity DSM, at last count only 15 states even required gas utilities to consider conservation options. Most people believe that at least at first, electricity programs will simply be transferred to gas utilities in a fairly wholesale manner. That might cause some problems, because there are profound differences between gas and electric companies in terms of everything from available capital to the nature of the resource itself. So the gas programs may start a little slowly and require some fine-tuning, but ultimately, the same larger principles about conservation are going to be applied to both gas and electric utilities.

It seems logical that before rebates can have the maximum effect on end user's behavior, the users have to receive the full rebate amount. But strange to say, that's not yet the case. That's because the IRS found out about this form of rebate and decided they ought to take a cut. They ruled that because rebates aren't paid by the equipment manufacturer or seller, they're taxable income for the rebate recipient. When that news broke about two years ago, it took more than a few utilities and users by surprise. To their credit, many utilities--who are supposed to report the payments to the IRS--knew the payments were taxaile and were informing their customers about it all along. Utility trade associations have been lobbying intensively to have the tax repealed, but it's a difficult issue politically, even though it's a step that everybody says they support. First, Congress is reluctant to give up even a fairly small revenue source. Second, because this

${ }^{21}$ Electric Utility Guide to Marketing Efficient Lighting. U.S. Department of Energy, Western Area Power Administration, Phoenix Area Office, P.O. Box 6457, Phoenix, AZ 85005. 
isn't a big enough issue to merit a bill of its own, it would have to be part of a larger reopening of the tax laws, which, in Washington, is like opening Pandora's box. Last year, the IRS issued a ruling that utility incentives in the form of rate cuts or nonrefunidable credits against future bills aren't taxable. But that won't do much good, because, as our small commercial energy survey showed, the incentive users really need is cash to offset the initial project cost.

So the policy makers are continuing to do battle, with the present consensus that if an appropriate tax-related bill comes along, the rebate tax repeal can be attached to it as an amendment, it would probably pass, but until then, recipients are still liable for taxes. The subject is so controversial that Congress decided to leave it out of the major energy bills that are pending--in part to keep those bills out of the Finance Committees.

Major state and federal policies regarding utility demand-side programs are being made today. These policies will have a tremendous impact on the business climate in your area. Now is the time to get involved, to let your legislators and regulators know how your community stands on these issues, and how the decisions they make will affect you. Don't assume they know what your needs are, make sure you tell them. 


\section{APPENDIX A - BIBLIOGRAPHY}

Lightwaves Lighting Energy Management Program. Taunton Municipal Lighting Plant, P.O. Box 870, Taunton, MA 02780-0870.

Pilot Commercial and Industrial Lighting Efficiency Program. Tucson Electric Power Company, 4350 East Irvington Road, P.O. Box 711, Tucson, AZ 85702

Sampling of Energy Use in Tucson's Small Commercial Buildings. Arizona Energy Office, Department of Commerce, 3800 North Central Ave., 12th floor, Phoenix, AZ 85012 .

DSM Guidebook. Volume 2: Commercial Technologies. prepared by SERI (Solar Energy Research Institute) for Western Area Power Administration, 1627 Cole Boulevard, P.O. Box 3402, Golden, CO 80401.

A Review of Utility Experience with Conservation and Load Management for Commercial and Industrial Customers. Steven Nadel, 1990, Washington, DC American Council for an Energy-Efficient Economy.

Utility Energy Strategies: The Role of Efficiency, Productivity and Conservation. CU6272, EPRI (Electric Power Research Institute) 3412 Hillview Avenue, P.O. Box 10412, Palo Alto, CA 94303.

Electric Rates and Company Comparisons. Tucson Electric Power Company, 4350 East Irvington Road, P.O. Box 711, Tucson, AZ 85702.

Planning for Stable Growth Pacific Power and Utah Power Resource and Market Planning Program, Volume 1, Summary Report, 1989.

Typical Residential, Commercial And Industrial Bills: Investor-Owned Utilities. July 1, 1991, Published by Rate Regulation Department, Edison Electric Institute.

Why Corporate America Moves Where. Fortune, New York, N.Y. 1982.

Energy Casebook. U.S. Department of Energy, Western Area Power Administration, Phoenix Area Office, P.O. Box 6457, Phoenix, AZ 85005.

DSM Customer Response. Volume 1: Residential and Commercial Reference Load Shapes_and DSM Impacis. EM-5767, EPRI, 3412 Hillview Avenue, P.O. Box 10412, Palo Alto, CA 94303.

Electric Utility Guide to Marketing Efficient Lighting. U.S. Department of Energy, Western Area Power Administration, P.O. Box 6457, Phoenix, AZ 85005. 
ASHRAE Standard 90.1 - 1989: Energy Efficient Design of New Buildings. American Society of Heating and Refrigerating Engineers, Inc. 1791 Tullie Circle, NE, Atlanta, GA 30329.

ASHRAE Standard 90A - 1980: Energy Efficient Design of New Buildings. American Society of Heating and Refrigerating Engineers, Inc. 1791 Tullie Circle, NE, Atlanta, GA 30329.

Commercial Sector Conserva on Technologies. LBL (Lawerence Berkeley Laboratory) No. 1 Cyclotron Road, Berkely, CA 94720

IES 1987 Applications Handbook. IESNA (Illuminating Engineers Society of North America) 345 East 47th Street, New York, NY 10017

Advanced Lighting Design Guidelines: Publication 400-90-014. California Energy Commission, Publication Office, 1516 Ninth Street, MS-13, Sacramento, CA 95814-5512.

Sources of Lighting Information and Services. U.S. Department of Energy, Western Area Power Administration, Phoenix Area Office, PO Box 6457, 615 South 43rd Ave., Phoenix, AZ 85005

Energy Conservation Behavior: The Difficult Path From Information to Action: 1986, American Psychologist 41:5, 521-528.

A Community Energy Action Program for the Tucson Metropolitan Area: Metropolitan Energy Commission of Tucson-Pima County, 1985, Summary report of the Arizona Office of Economic Planning and Development, Energy Division.

Arizona Energy Data Quarterly Report. Arizona Energy Office, March 1991.

Big Electric Utilities and Consumers Push Conservation Strategy. Bill Paul, Wall Street Journal, December 8, 1987.

Commercial Sector Electricity Conservation Workshop, Prepared for Utilities Division, Arizona Corporation Commission by Economic Research Associates, Lincoln, NE, February 1988.

Management Approaches to Energy Cost Savings in Existing Commercial Buildings. American Consulting Engineers Council, 1986. 


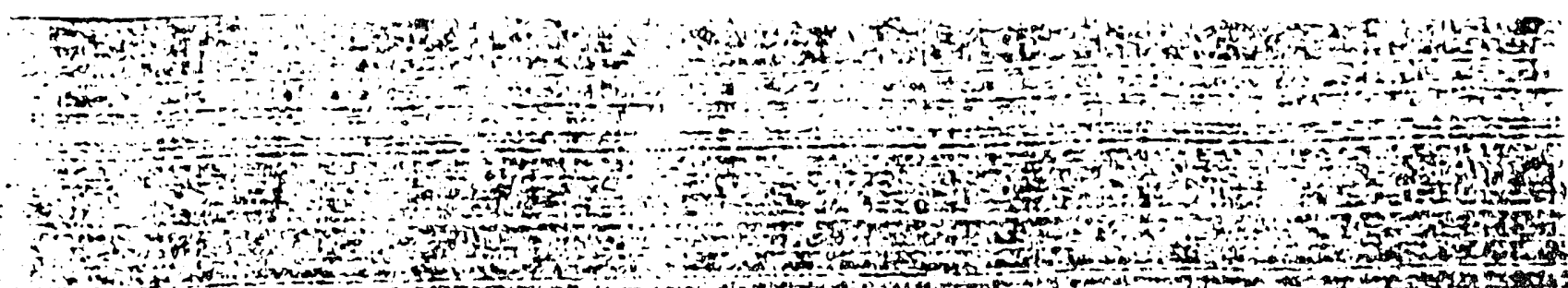

(3)

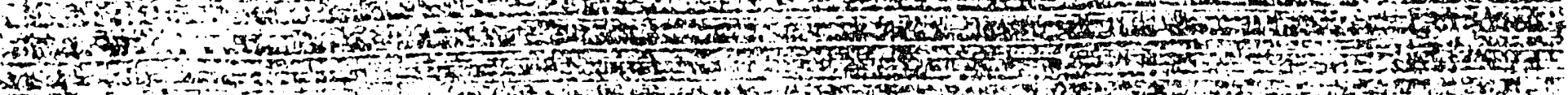

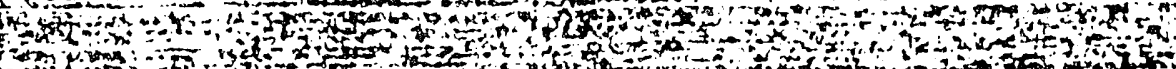

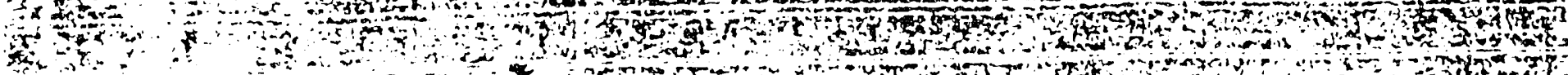
(a)

\section{IUCSON ELECIRIC POWLA CONIPNY}

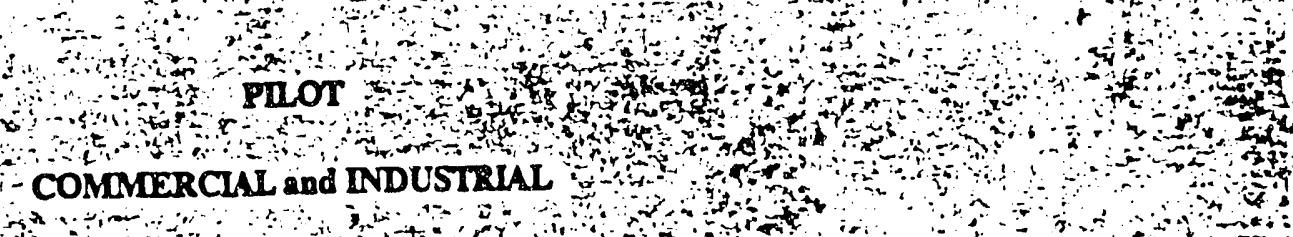

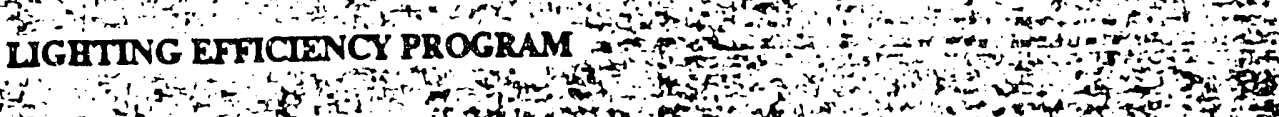
2400 J 15,1992 Jand (1)

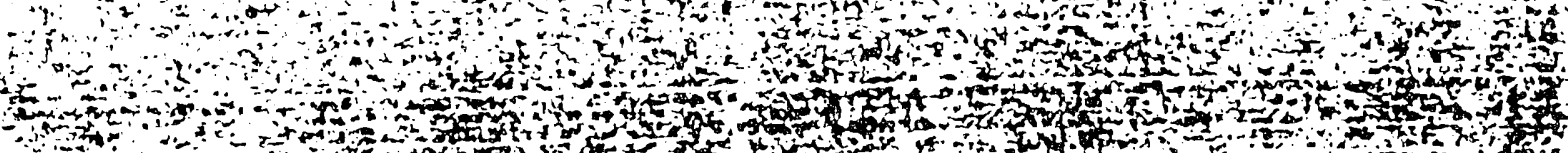

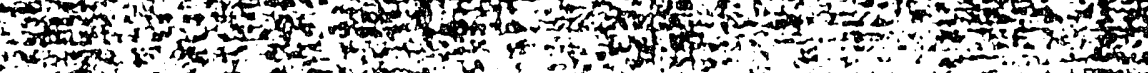
-10 -

然 a $\begin{array}{lll}1 & & \end{array}$ 


\section{TABLE OF CONTENTS}

Page

Introduction

Background 1

Program Goal

Qualifying Lighting Technologies

Program Cost Benefit Analysis

Budget 2

Limitations and Restrictions 2

Estimated $k W$ and $k W \cdot b$ Saved per Year 3

Cost to End User 3

Tucson Electric Power Company's Avoided Cost 3

Net Benefit of the Commercial and Industrial Lighting Effiriency Program 3

Program Marketing Plan

$\begin{array}{ll}\text { Participant Selection } & 4\end{array}$

Free Riders 5

PCB Capacitor Disposal Inceative 5

Program Monitoring Plan

Record-Keeping, Data Base and Program Evaluation 5

Program Evaluation Procedure 5

$\begin{array}{lr}\text { Monitoriag Marketing Efforts } & 8\end{array}$

$\begin{array}{ll}\text { Quality Control Plan } & 8\end{array}$ 


\section{Appendices}

\section{Appendix A}

Section I: Potential Peak Demand Reduction due to Lighting

Section II: Derivation of Avoided Cost to

$$
\text { Determine Rebate Level }
$$

Section III: Estimated Incentive Cost/kW

Section IV: $\quad$ Avoided Energy Cost

Section V: $\quad$ Lost Revenue Analysis

Section VI: Electronic Ballasts vs. High

Appendix B

Retro[it Rebate Schedule

Rebate Procedure

Appendix C

Distributor and Contractor List

Appendix D

Education and Promotional Plan

Appendix E

Commercial and Industrial Vew Construction

Lighting Efficiency Program

Participant Selection

Budget

28

Program Goal

28

Program Evaluation Procedure

28

Estimated System Impact 


\section{Introduction}

High-efficiency lighting programs are a proven, cost-effective means of reducing electrical energy demand and promoting conservation. However, due to the bigher cost involved in utilizing high-efficiency components and the lack of consumer knowledge, utilities throughout the country have found it necessary to provide tanancial as well as educational incentives to encourage customers to install energy effucient lighting systems.

According to conservative national estimates, $25 \%^{1}$ of a utility's peak demand is directly attributable to the lighting load from its commercial and industrial sectors. Using TEP's derived 1990 coincident commercialindustrial peak as a reference, this equates to $150.8 \mathrm{Mw}$ of commerciallindustrial lighting load for TEP. Assuming that only 50\% of that load can be encouraged to upgrade from standard core and coil Duorescent ballasts to ballasts exceeding minimum Federal standards and using higher efficiency lamps, there is a potential system demand reduction of $29.6 \mathrm{Mw}$. (See Appendix A Section I)

\section{Background}

In the Resource Planning Order, Decision. Vo. 57589, Tucson Electric Power was directed to implement an on-going demand side management program including conservation lighting. In the Rate Settemeat Agrecment, Decision .No. 57586, the Commission autborized the establishment of a $S 1$ million annual conservation and energy efficiency fund for the years 1991, 1992 and 1993. This fund will be used to promote conservation and energy efficiency in TEP's service area. In compliance witb these decisions, TEP's initial conservation program is the Cummercial and Industrial Lighting Efficiency Program.

\section{Program Goal}

The objective of TEP's Pilot Retroft Comsercial and Industrial Lighting Effuciency Program is to reduce peak demand and promute exergy coaservation. The goal for TEP's pilot program is to achieve a $445-k W$ reduction in total direct and indirect lighting demand by the completion of the pilot program in 1993. The estimated avoided energy cost and lost reveaue anatysis associated with the pilot program are contained in Appendix A Sections IV and V.

\section{Qualifying Lighting Technologies}

In addition to specular reflectors. TEP's pilot program will include all types of lighting modifications, techniques and devices which utilize energy-efficient techoology, and exceed minimum Federal standards. The program will include incentive rebales for occupanc; seasors and controls as well as provisions for daylighting. Rebates are restricted to indour lightiag systems of Commercial and ladustrial customers of TEP. Appeadix $B$ lists the incentive rebales for all qualifying devices. 


\section{Program Cost Benefut Analysis}

\section{Budget}

The Settlement Agreement contained in Decision 57586 includes a provision for the establishmeat of a Conservation and Energy Efficieacy Fund by TEP. For each of three years (1991, 1992 and 1993), $\$ 1$ million will be entered into the fund. The fund will be debited for all the costs associated witb TEP's conservation programs. These costs include administrative costs, monitoring and evaluation costs, and incentives granted to customers. Since the conversion of existing lighting systerns to more efficient componeats is one of the easiest and least expensive conservation measures that a business could cunsider, a large portion of the fund will be used for this purpose. An estimated $47 \%(\$ 1,100,000)$ of the $\$ 3$ million fund will be allocated to lighting. Approximatcly $70 \%$ of that amount will be affocated to incentive rebates and approximately $21 \%$ allocated for administrative costs. The remaining $9 \%$ will be used to cover educational and promotional costs.

The projected two-year total cost of the lighting program, including incentive rebates, promotional and administrative costs, is:

\begin{tabular}{|c|c|}
\hline $\begin{array}{l}\text { S } 975,000 \\
\text { S } 290,000\end{array}$ & $\begin{array}{l}\text { Incentive Rebates } \\
\text { Administrative Costs (includes } \\
\text { monitoring, evaluation and } \\
\text { PCB ballast disposal) }\end{array}$ \\
\hline 135,000 & Promotional Costs \\
\hline$\$ 00,00$ & TWO YEAR TOTAL \\
\hline
\end{tabular}

Annual expenditures for the program are anticipated to be:

$\begin{array}{ll}S 620,000 & \frac{\text { Year }}{1992} \\ \$ 780,000 & \text { 1993 } \\ \$ 1,+00,000 & \text { TWO YEAR TOTAL }\end{array}$

The amount budgeted for 1992 that is not expended will be carried forward to expand the program in 1993 During the course of the program, the total amount of inceative rebates will be allocated among the customer groups as follows:

\$ $\$ 50,000 \quad$ All Rate 14 customers and Rate 13 customers witb demands greater than 500-kW \$525,000 Rate 13 customers with de mands less than 500-kW; all Rate 10, Rate 12 and Rate 40 customers

\section{Limitations and Restrictions}

To easurc an even distribution of available funds throughout each customer category, individual customer incentive rebales will be limited annually as follows:

$\begin{array}{ll}\text { Amount } & \text { Customer } \\ \$ 50,000 & \text { Rate } 14 \\ \$ 35,000 & \text { Rate } 13 \\ \$ 15.000 & \text { Rates } 10,12 \text { and }+0\end{array}$

The minimum qualifying rebate is $\$ 100.00$ per customer account. 


\section{Estimated kW and kWh Saved per Year}

The estimated $\mathrm{kW}$ saved per year due to the lighting program is derived from the planoed annual incentive rebate expenditures and an estimated rebate cost of $5245.98 / \mathrm{kW}$ (See Appendix A Section III). We anticipate that there will be more program participants in 1993 due to the cumulative effect of the advertising and customer satisfaction. Therefore we estimated that approximately $44.4 \%$ of the rebate amounts will be distributed in 1992 asd $55.7 \%$ will be distributed in 1993 . The estimated direct $\mathrm{kW}$ reduction and $\mathrm{kWh}$ saved for each year is as follows:

\begin{tabular}{cccc} 
Year & Total Incentive Rebates & $\frac{k W R \text { Reduction }}{k W h \text { Saved }}$ & $\frac{\mathrm{kW}}{1992}$ \\
\cline { 2 - 3 } & $\$ 433,000$ & 1760 & $5,491,200$ \\
1993 & $\$ 543,000$ & 2207 & $6,885,840$
\end{tabular}

Although this is an ambitious goal, TEP believes it is acheivable. At the end of the pilot period, all aspects of the program will be evaluated to develop $2 \mathrm{n}$ appropriate permaneat lighting program. The estimated $\mathrm{kWh}$ savings as shown above are calculated in Appendix A Section V.

\section{Cost to End User}

As is the case with estimating the possible aumber of "free riders" discussed in the Program Marketing Plan section, extensive preliminary marketing research bas not been conducted to approximate the individual retront cost to customers participating in the program. Since this is a pilot program, it was decided that this type of data would be collected during the two-year pilot period The information gathered during this period will be used to improve the lighting program so that a full-scale program can be implemented in 1994. Informal observations of customers that bave completed lighting retrofits without incentives from TEP indicate that the costs of energy efficieat lighting products are not unusually high in Tucson.

Tucson Electric Power Company's Avoided Cost

The calculated avoided cost of geseration on the TEP system in 1992 dollars is $\$ 66.98$ ikW/year for a combustion turbine (Appendix A Section II). Incentive rebates for this Pilot Conservation Lighting Program have been established at a lesser amouat to easure that the total cost of the program is less thas the avoided cost of plant additions. Also, the avoided fuel costs bave not been included in developing the incentive rebate amounis to assure a less costly program. Although there may be avoided costs associated with transmission and distribution facilities for commercial and industrial customers, they bave not been included in this analysis.

locentive rebate amounts are based on direct lighting load reduction only and do not include any rebate for the estimated cooling load reduction. By basing rebates on only the direc: lighting load reduction, the cost of the program will be kept as low as possible to advance the objective of developing a lighting program which is a least cost option to future plant additions. Althougb customers will not get a rebate for the reduced cooling load, they will benefit from a lower cooling portion of the is electric bills as a result of the lighting retrofit. During the pilot program the incentive rebate amount may be adjusted to improve customer participation levels but the amouat will remain consisteat with the requiremeat that total program costs be less than the cost of building equivalent plant additions.

\section{Net Benefit of the Commercial and Industrial Lighting Eficiency Program}

TEP does not have sufficieat data at this time to accuratety estimate the net benefit of the Commercial and Iadustrial Lighting Elficieacy Program. However, since this is a pilot program, the data required to develop a valid estimate of actual utility savings and social costs will be collected during this period. A preliminary estimate can be calculated using the following equation:

Net Beocift $=$ (Avoided Capacity cost + Avoided Energy Cost $) \cdot(2$ Year Program Cost + Lost Reveque $)$ 
The average avoided capacity cost $\mathrm{kW}$ from the table in Appendix A. Section III is $\$ 369.20 / \mathrm{kW}$. Multiplying the projected $3967 \mathrm{~kW}$ of direct reduction and $478 \mathrm{~kW}$ indirect reduction over the two year pilot period by that a mount results in an avoided capacity cost of $\$ 1,641,094$.

The avoided energy cost from Appendix A, Section IV is $\$ 334,141$.

The budgeted two year program cost is $\$ 1,400,000$ and the estimated lost revenue from Appendix A, Section $V$ is $\$ 308,475$.

Therefore:

Net Benefit $=(\$ 1,641,094+\$ 334,1+1)-(\$ 1,400,000+\$ 308, \downarrow 75)=\$ 266,760$

The Net Benefit of the pilot Commercial and Industrial Lighting Efficiency Program is $\$ 266,760$. As previously mentioned, this analysis does not take into consideration any potential transmission and distribution avoided costs.

\section{Program Marketing Plan}

\section{Participant Selection}

The qualifying categories for retrofit incentive rebates will be all commercial and industrial customers including Rate 10, Rate 12, Rate 13, Rate 14 and Rate 40. Solicitation of all Rate 14 customers and Rate 13 customers whose demand exceeds $500 \mathrm{~kW}$ will be conducted by Account Executives through direct contact and a special mailing of program information. These customers will work directly with their Accoun? Erecutives.

At the initiation of the program and again in the 1993 billings. Rate 40, Rate 10, Rate 12 and Rate 13 customers with demand less than $500 \mathrm{~kW}$ will be solicited by means of direct mail. Due to the large number of these customers, they will be informed that program materials are available upon request through the Conservation and Load Management Deparment. Included with the progran information provided to the customer will be an application form which must be completed and returned to TEP in order to participate. A list of all customers who request materials will be maintained to determine the level of general interest.

Lpon receipt, the application will be dated and time-stamped to indicate priority for receipt of funds. After approval of the application, customers will be ootified that they are approved to participate in the pilot lighting program.

Funds for incentive rebates will be distributed on a tirst-come, first-served basis. A customer will retain priority for fund distribution according to the date stamped on the application by TEP.

During the course of the program, if demand reduction and participation goals are not being met, marketing cfforts will be increased. Rebatc amounts will be reviewed each year to ensure the highest participation level pussible while maintaining a least cost uption. If participation levels are lower than projected in any category, program marketing efforts will be reviewed and modified if appropriate. If modified marketing efforts Jo nut result in the projected participation by these non-attainment categories, unexpended amounts will be used to lund increased participation in the otber categories. 
Educational brochures highlighting the benefits of efficient lighting systems will be distributed to encourage program participation through TEP's Account Executives, the Small Commercial Energy Audit Program and direct mail. Educational seminars tailored to the needs of business owners, building managers, architects, engineers, vendors and lighting contractors will be sponsored by TEP to provide information about TEP's programs and to inform them of the latest energy-saving lighting technologies. Advertising in select trade or other publications will inform customers of the program and benefits of encrgy-efficient lighting. Additional details about the eduation and promotional plan is found in Appendix D.

\section{Free Riders}

Many other utilities bave proven that the implementation of a lighting rebate program is a successful means of reducing peak demand and promoting conservation. Based on these findings, TEP decided that its time, would be better spent developing and implementing a commercial and industrial lighting program rather than conducting extensive sarketing studies which would delay the start of a program. For this reason. TEP does not currently have an estimate of the number of "free riders" who may participate in the lighting program. During the two-year pilot study, free rider data will be gathered through marketing surveys and participant follow-up questionaires.

\section{PCB Capacitor Disposal Incentive}

The Commercial and Industrial Lighting Efficiency Program will stress the replacement of old core and coil ballasts with bybrid or electronic ballasts. Since many of these old ballasts may have beer manufactured prior to 1979, they may contain PCB capacitors and therefore stould not be disposed of in Tucson's local landfills. The proper disposal of a PCB capacitor requires that it be carefully removed from the ballast and incinerated. However, this procedure is very costly and therefore may deter some customers from participating in the program. To remove this deterrant to participation. TEP will property dispose of all PCB ballasts for program participants as pan of its program costs.

\section{Program Monitoring Plan}

\section{Record-Keeping Data Base and Propram Evaiuation}

To evaluate the pilot program's effectiveness in achieving customer participation and demand reduction goals, a data base containing the following will be maincained:

1. Customer's name, service address and SIC code number.

2. Type and aumber of measures implemented and equipment removed.

3. Incentive rebate amuunt.

4. Estimaled $k W b$ and oa-peak $k W$ reduction.

5. Actual demands and energy use before and after the retrofit, normalized for weatbcr. If the customer's normal billing dues aot ioclude a de mand amounat, energy consumption before and after the retrofith normalized for weather, will be utilized to estimate the actual demand reduction. Load survey meters will be used in sufficicat quantity to verify demand and energy reductiva estimates.

Program educationah promotiunal and adoninistrative costs will be captured in establisbed accounts. 


\section{Program Evaluation Procedure}

Tu quantify the impact of the Retrofit Commercial and Industrial Lighting Efficiency Program, a sample number of customers from each of the customer classes (Rate 10,12, 40,13 and 14) who apply and qualify for participation in the program will be asked to cooperate in TEP's data collection process. This sample will be selected by SIC code. energy use and dicmand. Load survey meters will be installed at each of the selected locations at least one month before the lighting retrofit is implemented to collect existing load data. The load survey meters will be left in place one or two months after the equipment installation is complete to measure the impact of the retrofit. During the collection period, the customer will be asked to record any significant changes in work schedule, production level, personnel, etc., which could impact demand or $\mathrm{kWb}$ consumption. Customers will be asked to keep these variables as stable as possible during the data collection period.

The collected data will be normalized for weather and normalized demand and $\mathrm{kWh}$ reduction will be calculated for the test period. This information will then be used to estimate an annual de mand and $\mathrm{kWh}$ reduction. At the end of the pilot program, these data will be used to estimate the expected impact on demand and lost reverue that a full-scale lighting program may bave. A flowchart of the program evaluation procedure is found on the following page. 
Key

Inputs
Action

Steps

- ACこ Recommendation

- am\&A Recommendations

- Peak Demand Reduction Goal

- Posidone Generation Requirement Goal

- AEZ Recommendation

- רusiry DSM Program Data

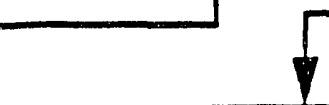

variaole

Speed

Drives

- Review Other Utility Programs

* Establish Rebate Levels

* Estimate Cost of Program

- Cosi op Program

* -oad Researcn Results

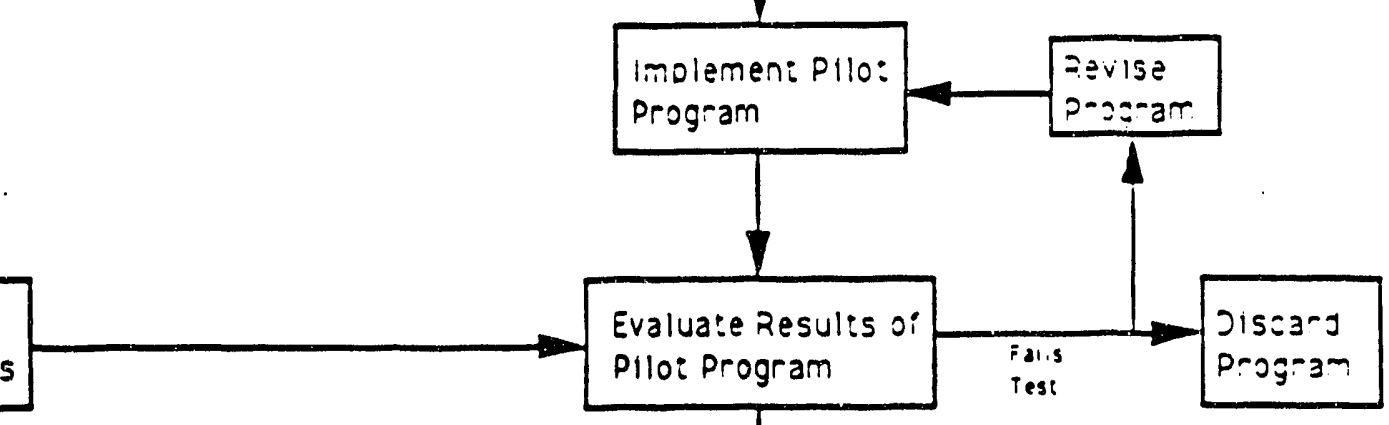

Passed Test

Develoo Pilo:

Proaram

Commercial \&

industrial

Lignting

Develop Pool of

Candidate Programs

Commerctal \&

Industrial

Lignting

storage

ignest

Aankes

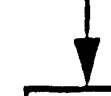

Thermal

- Lajo Jata

- Ijsi jaia

- Marke: Penetration

- Program joals

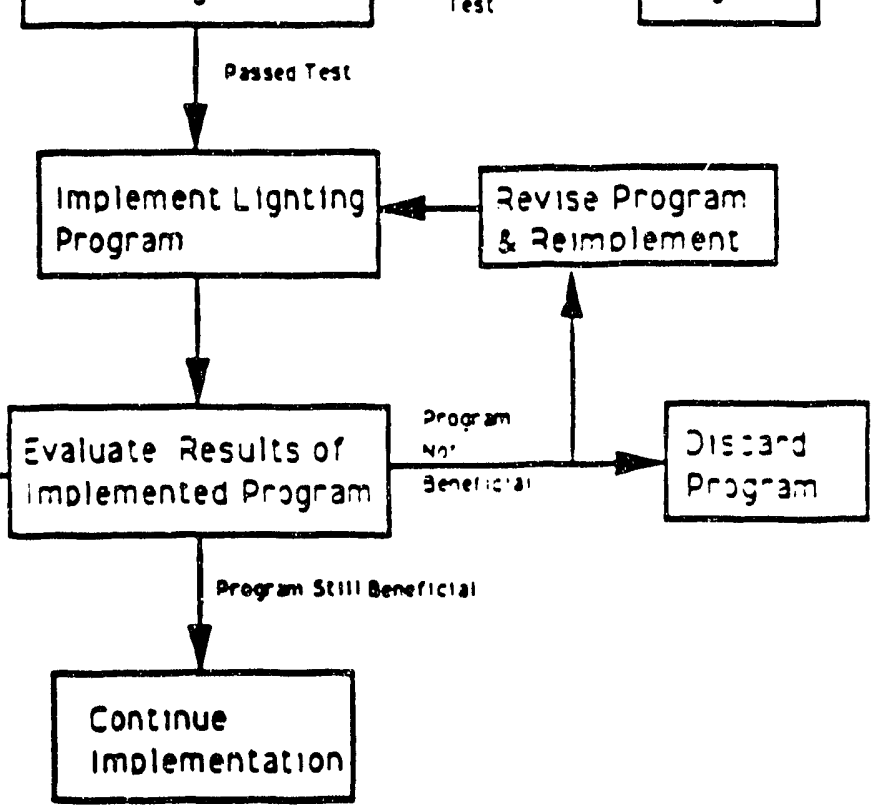


Marketing Monitoring Efforts

A market research program will be implemented to monitor the effectiveness of the Company's Educational and Promotional Plan in achieving the program's demand and participation goals.

Required information will be gathered through a combination of formal and informal research methods. Formal research will include mail surveys, interview studies, secondary analysis and customer focus groups. Informal methods, which typically dominate market research projects, will also be used. TEP's informal research will utilize personal customer contacts through the Account Executive program, feedback from Commission Staff and knowledgeable industry leaders, reviews of unsolicited customer comments and analysis of news media coverage.

\section{Quality Control Plan}

Quality Control will be monitored by on-site inspections before and after the retrofit. A more detailed explanation of the rebate procedure is found in Appendix B. 


\section{APPENDIX A}

\section{Supporting Data}

\section{Section 1: Polential Peak Demand Reduction Due to Lighting}

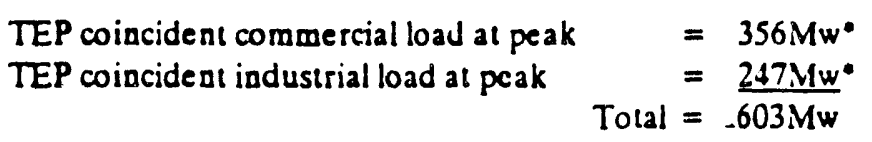

Assuming 25\% of peak is due to Commerciallndustrial lighting (not including cooling contribution) $(603 \mathrm{Mw})(25)=150.75 \mathrm{Mw}$ Lighting

Target lighting load for demand reduction assuming even distribution of lighting load among customers and 50\% pasticipation

$$
(150.75 \mathrm{Mw})(5)=7538 \mathrm{Mw}
$$

Estimated demand reduction for a fluorescent fixture retrofit:

$$
\begin{aligned}
& \text { Standard Core \& Coil Ballast (1.15 BF), } \\
& 4-10 \text { Wall lamps } \\
& \text { Electronic Ballast (.88 BF), } \\
& 4.34 \text { Wall lames } \\
& \text { TOTAL REDLICTION }
\end{aligned}
$$

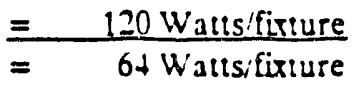

Commercialindustrial direct lighting de mand reduction goal:

$$
(35)(75.38 \mathrm{Mw})=26.38 \mathrm{Mw}
$$

Polential indirect demand reduction in cooling load (assume SEER 3.5 BTU/W):

$$
\begin{array}{rll}
\text { Cuefficient of Performance } & =(85 \mathrm{BTU} / \mathrm{W}) /(3.412 \mathrm{BTU} / \mathrm{W}) & =2.49 \\
\text { Estimaled lodirect Reduction } & =(26.38 \mathrm{Mw} / 2.49)\left(3^{\circ *}\right) & =3.18 \mathrm{MW}
\end{array}
$$

Total Potential Peak Demand Reduction Due to Lighting

$$
\begin{aligned}
\text { Direct } & =26.38 \mathrm{Mw} \\
\text { Indirect } & =3.18 \mathrm{Mw} \\
& =29.56 \mathrm{Mw}
\end{aligned}
$$

- Response of TEP to R14-2.703 Vitibly Reporting Requirements of the ACC Resource Planaing Rules. April 1. 1991, page 65, muntb of August, 1990. Coincident load for the mises, APC and Liquid Air is $126 \mathrm{Mw}$ from the Rate case. lest year eaded June 1990. The $2+7$ Mw of Industrial load excludes the mines, APC and Liquid ive (373Mw - 126Mw). The $373 \mathrm{Mw}$ is the August 1990 cotal Industrial coincideat load at peak also from the Response of TEP to R 14-2-703.

$\because \quad 30 \%$ probability that air-conditioning load is on during system peak (ACC Stall Reporh, November 9. 1990, page 86) 


\section{Section Il: Derivation ol Avoided Cost to Determine Rebate Level}

\section{Capacity Cost of a Combustion Turbine Unit in 1992 Dollars}

The avoided cost of capacity for the lighting program is based on the avoided cost of installing a 75 MW combustion turbine unit in the year 2000. The analysis was done excluding non-plant $A$ \& $G$ plant loading and assuming a 7 percent discount rate which results in a cost of $\$ 66.98 / k W / y e a r$. For this analysis, it bas been assumat that the total capacity cost associated with each $\mathrm{kW}$ of demand reduced will be avoided. A table showing the computation of the annual marginal demand related capacity cost of generation is shown below.

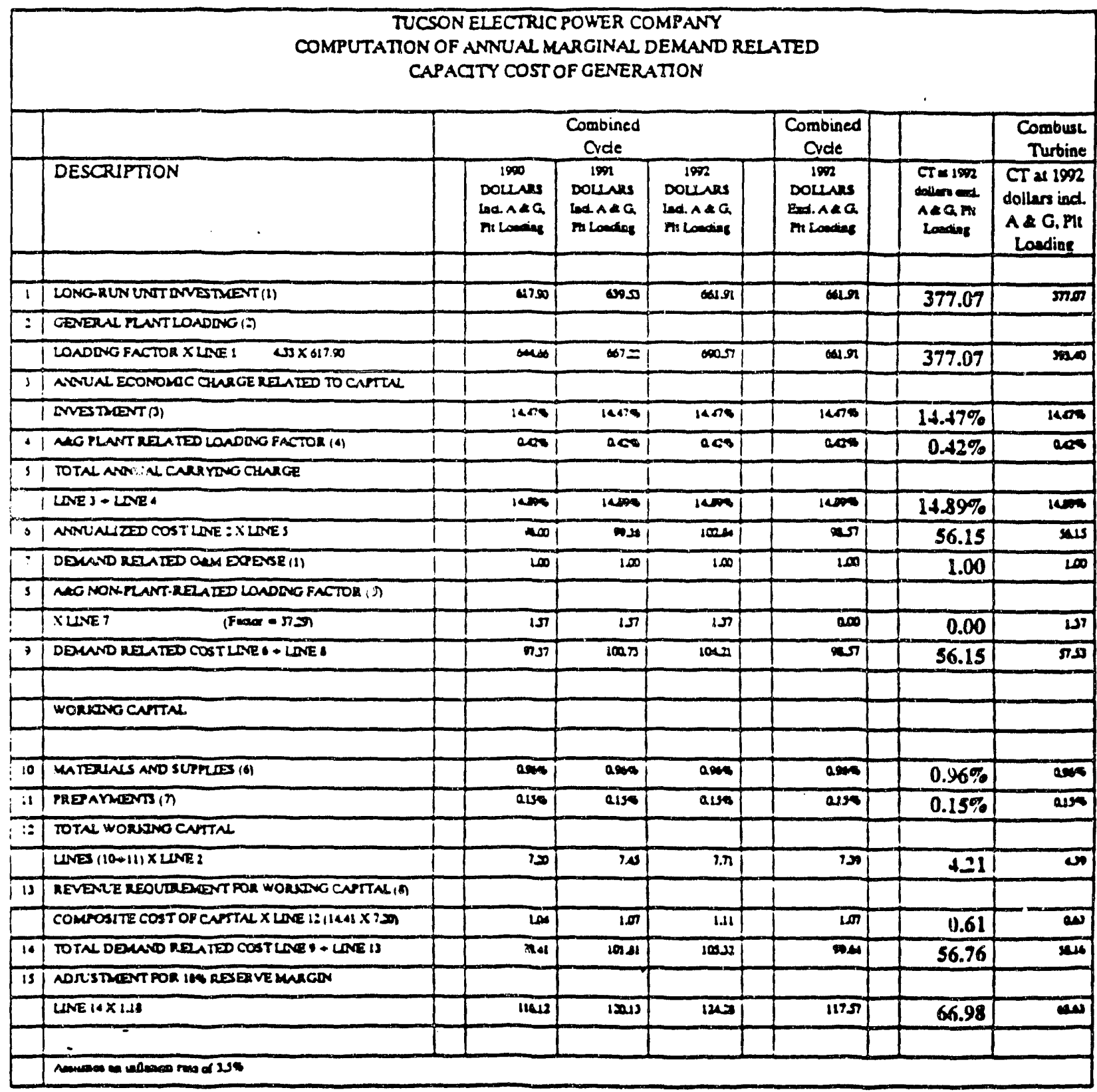




\section{Other Avoided Costs}

The avoided cost of transmission and distribution facilities have not been included in determining the incentive rebate amounts for this program. Likewise, the avoided fuel cost has not been used in the calculations.

There is an avoided cost associated with environmental externalities. However, the actual cost is extremely difficult to quantify. Some jurisdictions bave added an amount of $1 \mathrm{cen} / \mathrm{kWh}$ to the avoided energy cost of a conservation measure to quantify program impacts on the eavironment. Although TEP agrees that the environmental impact of this and other conservation programs will be positive, a value for the avoided cost of eavironmental exteraalities bas not been explicitly included in the avoided cost calculations for this program.

\section{Section III: Estimated Incentive Cost $\mathrm{kW}$}

To estimate the incentive cost $/ \mathrm{kW}$ of reduction due to the lighting rebate progtam over the two-year pilot program, four typical retrofit options based on 100 fixtures were assumed. The cost/kW for each retrofit was then calculated. The four rebate costs were then averaged to calculate the estimated rebate cost $/ \mathrm{kW}$ of reduction.

Existing Lighting Svstem

$1002 \times 4$ Fluorescent firtures each containing:

$\frac{\text { Number of lamps/firture }}{440 \text {-Watt }} \quad 12 \frac{\text { Ballast Factor }}{\text { (old Core \& Coil) }} \quad \frac{\text { Watts/firture }}{192} \quad \frac{\mathrm{kW} \text { 'svstem }}{19.2}$

Option 1

lostalling energy saving 34 watt lamps only.

$\frac{\text { Number of lamps/fixture }}{434-W a t t} \quad \frac{\text { Ballast Fic:or }}{12 \text { (old core \& coil) }} \quad \frac{\text { Wattsifirture }}{1632} \quad \frac{\mathrm{kW} \text { s.stem }}{1632}$

Qption?

Installing energy saving 34 watt lamps and electronic ballasts.

\begin{tabular}{|c|c|c|c|}
\hline Number of la & Ballast Factor & Walts/firture & kW:sustem \\
\hline $434 W_{\text {att }}$ & 0.88 (electronic) & 119.7 & 11.97 \\
\hline
\end{tabular}

\section{Option 3}

Installing energy saving T-S lamps and electronic ballasts.

$\frac{\text { Number of lamps/fixture }}{432 . W_{a} s t} \quad \frac{\text { Ballast Factor }}{0.38 \text { (electronic) }} \quad \frac{\text { Watts/firture }}{112.64} \quad \frac{\mathrm{kW} \text {; }}{1126}$

\section{Ontion 4}

Installing energy saving T \& lamps, electronic ballasts and reflectors.

\section{Numbernflamps/lixture \\ 232.Walt \\ -}

$\frac{\text { Ballast Factor }}{0.38 \text { (electronic) }}$
Walts/fixture

56.32
$\mathrm{kW/system}$

5.63 
A summary of the rebate amounts which would be given for each one of these options and the costkw reduction is given below.

Rebate Amounts and Cost/kW Reduction

\begin{tabular}{|c|c|c|c|c|c|c|c|c|c|c|}
\hline Contion & $\begin{array}{c}\frac{\text { Tolal }}{\text { Lamp }} \\
\text { Rebate }\end{array}$ & $\begin{array}{l}\frac{\text { Total }}{\text { Ballast }} \\
\frac{\text { Rebate }}{\text { Ret }}\end{array}$ & $\begin{array}{c}\frac{\text { Total }}{\text { Reflector }} \\
\text { Rebaic }\end{array}$ & $\frac{\text { Option }}{\frac{\text { Total }}{\text { Rebate }}}$ & $\frac{\frac{\text { Option }}{\text { Total }}}{\frac{\text { Cost }}{\text { On }^{*}}}$ & $\begin{array}{l}\frac{\text { Option }}{\text { Avnided }} \\
\frac{\text { Capacirv }}{\text { Cost }}\end{array}$ & $\frac{k W}{\text { Reduction }}$ & $\begin{array}{l}\text { Rebate } \\
\text { Cost kw }\end{array}$ & $\begin{array}{c}\text { Total } \\
\text { Option } \\
\text { Costikwe }\end{array}$ & $\begin{array}{l}\text { Avoided } \\
\text { Capacivy } \\
\text { Cost } / \mathrm{kW}\end{array}$ \\
\hline 1 & $\$ 300$ & none & Done & 5300 & $5+31$ & 5452 & 2.38 & $\$ 104.17$ & $\$ 149.65$ & $\$ 156.94$ \\
\hline 2 & 5300 & $\$ 2+16$ & none & $\$ 2716$ & $\$ 3900$ & 54076 & 723 & $\$ 375.66$ & 5539.42 & $\$ 563.76$ \\
\hline 3 & $\$ 400$ & 51208 & Done & $\$ 1608$ & $\$ 2309$ & $52+12$ & 7.94 & 520252 & $\$ 290.81$ & $\$ 303.78$ \\
\hline$t$ & $\$ 200$ & $\$ 1208$ & $\$ 2684$ & 54092 & $\$ 5876$ & 56138 & 1357 & $\$ 301.55$ & 5433.01 & $\$ 45232$ \\
\hline Aicrage & & & & & & & & 5245.98 & 5353.22 & 5369.20 \\
\hline
\end{tabular}

- Includes $\$ 3.6 \%$ of the rebate cost for administrative and promotional costs.

Averaging the rebate cost $/ \mathrm{kW}$ for the four options given above results in an estimated cost of $5245.98 / \mathrm{kW}$. 


\section{Section IV: Avoided Energy Cost}

The estimated avoided eaergy cost associated with the two-vear pilot program is as follows:

Assume a typical customer's business hours are 8:00 AM - 4:30 PM-Monday through Friday Lights are on 7:00 AM - 7:00 PM (12 hours/day or 3120 hours/year)

TEP'S ON-PEAK \& OFF-PEAK HOURS

$\begin{array}{lll}\text { Summer } & \text { On-Peak } & \text { 10:00 AM - 10:00 PM } \\ \text { Off-Peak } & 10: 00 \mathrm{PM}-10: 00 \mathrm{AM} \\ \text { Winter } & & \\ & \text { On-Peak } & \text { 7:00 AM - 11:00 AM } \\ & 6: 00 \mathrm{PM}-9: 00 \mathrm{PM} \\ & \\ & \text { Off-Peak } & 11: 00 \mathrm{AM} \cdot 6: 00 \mathrm{PM} \\ & 9: 00 \mathrm{PM}-7: 00 \mathrm{AM}\end{array}$

ESTMMATED REDUCTION IN DEMAND

$19921760 \mathrm{~kW}$ direct $+212 \mathrm{~kW}$ indirect $=1972 \mathrm{~kW}$

$19932207 \mathrm{~kW}$ direct $+266 \mathrm{~kW}$ indirect $=2473 \mathrm{~kW}$

Both the direct and indirect reduction due to cooling are used for the summer cost calculation. Only the direct reduction is used for the winter calculation. Cooling equipment run time is estimated at $70 \%$ of lighting time during the summer.

1992 \& 1993 Summer

Lighting

On-Peak $=9 \mathrm{brs} /$ day $\cdot 5$ days/wk $\cdot 26$ wksiyr $=1170 \mathrm{hrs}$

Off-Peak $=3 \mathrm{hrs} / \mathrm{day} \cdot 5 \mathrm{days} / \mathrm{wk} \cdot 26 \mathrm{wks} / \mathrm{yr}=390 \mathrm{hrs}$

Conling

On-Peak $=1170 \mathrm{hrs} \cdot 0.7=819 \mathrm{hrs}$

Off.Peak $=390$ hrs ${ }^{\circ} 0.7=277$ brs

1992 \& 1993 Winter

Liphting

On-Peak $=5 \mathrm{brs} / \mathrm{day} \cdot \mathrm{S}$ dayshwk $\cdot 26 \mathrm{wks} / \mathrm{yr}=650 \mathrm{brs}$

Off-Peak $=7 \mathrm{brs} / \mathrm{day} \cdot \mathrm{s}$ days $/ w \mathrm{k} \cdot 26 \mathrm{wks} / \mathrm{yr}=910 \mathrm{brs}$ 


\section{ESTIMATED AVOIDED ENERGY COST*}

(Ceats per $\mathrm{kWh}$ )

\begin{tabular}{ccc} 
& \multicolumn{2}{c}{ Summer } \\
& \multicolumn{2}{c}{ May l-October 31) } \\
\cline { 2 - 3 } & \multicolumn{1}{c}{ On-Peak } & Off-Peak \\
1992 & 2.653 & 2.302 \\
1993 & 2.781 & 2.345
\end{tabular}

\begin{tabular}{cc} 
Winter \\
November & - April 30) \\
\hline On-Peak & Off-Peak \\
2.624 & 2.418 \\
2.727 & 2.497
\end{tabular}

- TEP's 1990 avoided cost filing. This cost includes fuel and variable O \& M.

Cost Calculation

1992 Summer

Lighting

On-Peak $1170 \mathrm{hrs} \cdot 1760 \mathrm{~kW} \cdot 50.02653 / \mathrm{kWh}=554,63058$

Off-Peak $390 \mathrm{brs} \cdot 1760 \mathrm{~kW} \cdot 50.02302 / \mathrm{kWh}=$ S $15,800.93$

Cooling

On-Peak $=819 \mathrm{hrs} \cdot 212 \mathrm{~kW} \cdot 50.02653 \mathrm{kWh}=$ S 4,60635

Off-Peak $=273 \mathrm{krs} \cdot 212 \mathrm{~kW} \cdot 50.02302 \mathrm{kWh}=$ S 1,33231

Winter

Lighting

On-Peak $650 \mathrm{hrs} \cdot 1760 \mathrm{~kW} \cdot \$ 0.02624 / \mathrm{kWh}=\$ 30,018.56$

Off-Peak $910 \mathrm{hrs} \cdot 1760 \mathrm{~kW} \cdot \mathrm{SO} 0.02+18 / \mathrm{kWh}=\$ 38,726.59$

1993 Summer

Lighting

On-Peak $1170 \mathrm{hrs} * 2207 \mathrm{~kW} \cdot \$ 0.02781 / \mathrm{kWb}=\$ 71,810.70$

Off-Peak $390 \mathrm{hrs} \cdot 2207 \mathrm{~kW} \cdot 50.02345 / \mathrm{kWh}=\$ 20,184.12$

Cooling

Oa-Peak $=819 \mathrm{brs} \cdot 212 \mathrm{~kW} \cdot \$ 0.02781 / \mathrm{kWb}=\$ 6,058.52$

Off.Peak $=273 \mathrm{brs} \cdot 212 \mathrm{~kW} \cdot 50.023+5 / \mathrm{kWb}=$ S $1,702.39$

Winter

Lighting

On-Peak $650 \mathrm{hrs} \cdot 1760 \mathrm{~kW} \cdot \$ 0.02727 / \mathrm{kWh}=\$ 39,120.18$

Off-Peak $910 \mathrm{krs} \cdot 1760 \mathrm{~kW} \cdot \$ 0.02497 / \mathrm{kWh}=\$ 50,149.00$

TOTAL ANNUAL AVOIDED ENERGY COST FOR THE PILOT PROGRAM

$1992 \$ 145,115.42$

$1993 \quad \$ 189.025 .41$

Total avoided energy cost for the pilot lighting program is 5334,141 .

Section V: Lost Revenue Analysis

The following analysis estimates the effect of the Retrofit Commercial and ladustrial Lighting Efficiency Program on revenue. There are two groups in the pilot program. Group 1 consists of Rate 13 customers with demand greater than $500 \mathrm{~kW}$, and all Rate 14 customers Group 2 consists of Rate 10, 12 and 13 customers with demand less than $500 \mathrm{~kW}$. For both groups, the minimum and the maximum reduction in revenue is calculated based on the approved rates in Decisiou 57586 for 1992 and projected rates for 1993. The actual reduction in revenue will tall somewhere withia these limits dependiog on which customers take advantage of the program. 
The assumption is that the program will produce a reduction in direct lighting load of $1760 \mathrm{~kW}$ for 1992 and $2207 \mathrm{~kW}$ for 1993. There will also be an indirect reduction for cooling load. This indirect reduction will be $212 \mathrm{~kW}$ for 1992 and $266 \mathrm{~kW}$ for 1993. For the purpose of this report, the allocation of the load reduction between groups is based on the inceative rebate amounts. See Table 1 for the breakdown of the incentive rebate amounts. Other factors necessary to calculate the revenue reduction are included in Table 2.

Table 1

Group Allocation Factors.

\begin{tabular}{|ccc|}
\hline Incentive Rebace & & \\
Group 1 & $\$ 450,000$ & $46.15 \%$ \\
Group ? & $\$ 595,000$ & $\$ 3.85 \%$ \\
Tow & $\$ 975,000$ & $100.00 \%$ \\
\hline
\end{tabular}

Table 2

Billing Information

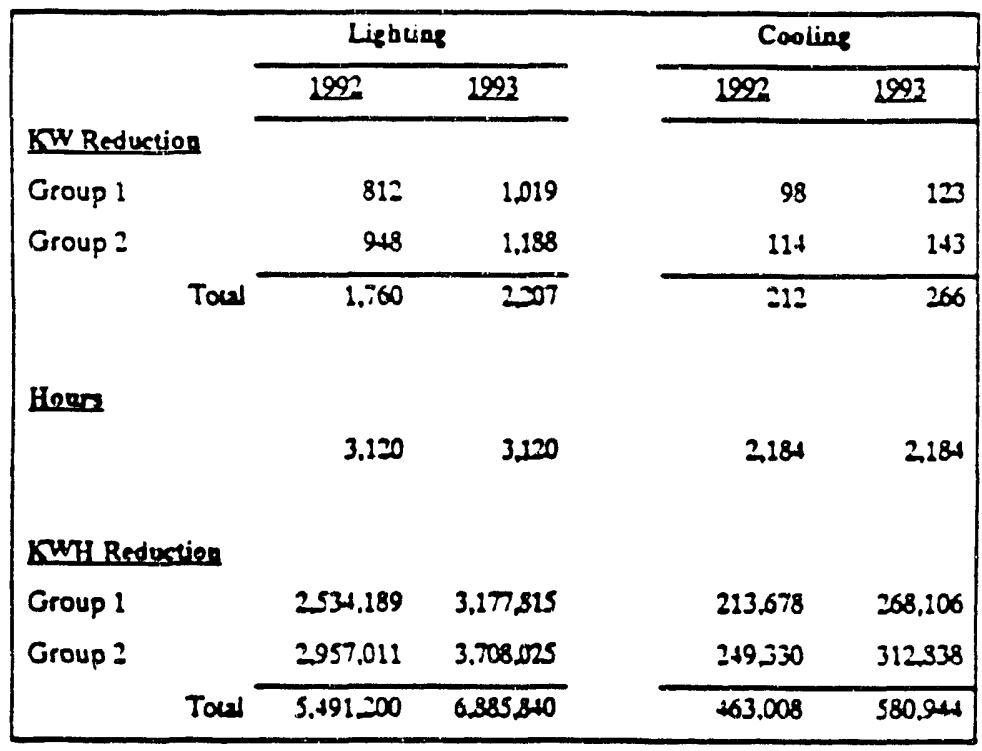

The rates used for 1992 and 1993 were the rates approved by the Arizona Corporation Commission in the October 1991. Decision 57586 plus $45 \%$ in 1993. An avoided enersy cost for botb Group 1 and Group ? (containing two mils of variable $O \& M$ cost) was calculated to adjust for fuel not burned due to the reduction in load. The calculation of the avoided energy cost can be found on page 14. 
Table 3 shows the reduction in revenue by group for the pilot program. The table shows the reduction in each group by rate and an average of both rates. For Group 1 , Rates 13 and 14 were used to calculate the upper and lower limits. For Group 2, Rates 10 and 13 were used to calculate the upper and lower limits. Rate 12 is not included in Group 2 since the rate is frozen and its impact on this study would be insignificant. The actual reduction in revenue will fall within these limits depending on the rate class of the customers taking advantage of the program. Toe actual reduction in revenue for Group 1 lies between \$278,527 and $\$ 263,108$ with an average reduction of $\$ 270,818$. The actual reduction in revenue for group 2 lies between $\$ 367,371$ and $\$ 324,893$ with an average reduction of $\$ 346,132$. Therefore, the estimated average revenue reduction for the total Pilot Retrofit Commercial and Industrial Lighting Efriciency Program is \$308,475.

\section{Table 3}

Revenue Reduction By Group

\begin{tabular}{|c|c|c|c|c|c|c|c|}
\hline \multirow{3}{*}{$\begin{array}{l}\text { Goren } \\
\text { Bate } 13\end{array}$} & \multicolumn{3}{|c|}{ Liphting } & \multicolumn{3}{|c|}{ Cooling } & \multirow{2}{*}{$\begin{array}{l}\text { Toul } \\
\text { Pilot } \\
\text { Proseam }\end{array}$} \\
\hline & 1992 & 1993 & $\begin{array}{c}\text { Toul } \\
\text { Lishlins }\end{array}$ & 1992 & 1923 & $\begin{array}{l}\text { Total } \\
\text { Coolins }\end{array}$ & \\
\hline & & & & & & & \\
\hline Danad & $9950 \times 16$ & 720682 & 1502000 & A & 2,7006 & 16001.10 & Lsen.x \\
\hline Eard & 15657.10 & $\operatorname{ses} 19.98$ & 261.7938 & اתعمدا & 1731065 & $30512 x$ & $3272 \Omega$ \\
\hline \multirow{2}{*}{$\begin{array}{l}\text { Avoided } \\
\text { Enere Con } \\
\text { Tow }\end{array}$} & -124.110 .46 & בת $131=$ & . & Susas & $.5015=$ & $-11,00012$ & -20s \\
\hline & 589.909 .10 & $515=200$ & 5020939 & 81500206 & 20116587 & 234.197 .93 & 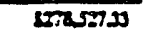 \\
\hline \multicolumn{8}{|l|}{ Bate 14} \\
\hline Denand & rssors & 127,7000 & $2 \cos 14$ & תבתבו1 & 1460909 & 250005 & 20000 \\
\hline Ener & 11620059 & 1529987 & 20405756 & 2000.55 & 320ses & 2007.x & sisss \\
\hline $\begin{array}{l}\text { Avoded } \\
\text { Eneros con }\end{array}$ & $-12 a 41 a \times 6$ & בהאיצונו. & $.87, \pi 407$. & 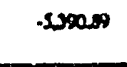 & $.2015=$ & $-11,00511$ & 2004 \\
\hline Toan & 2027120 & $31+2007.86$ & Essouss & 3LS519.94 & 221.9825 & D7,sse = & masuess \\
\hline 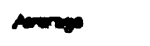 & $40150 \pi$ & s17sease & 501009.76 & 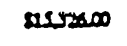 & 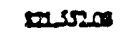 & 104m & Exonts \\
\hline \multirow[t]{2}{*}{ Gman? } & & Lighting & & \multicolumn{3}{|c|}{ Cooling } & Toual \\
\hline & 2092 & 1929 & $\begin{array}{c}\text { Toral } \\
\text { Linhtias }\end{array}$ & 2922 & 1093 & $\begin{array}{l}\text { Total } \\
\text { Coolins }\end{array}$ & $\begin{array}{c}\text { Pilot } \\
\text { Brostan }\end{array}$ \\
\hline \multicolumn{8}{|l|}{ Batedo } \\
\hline senen & $100 \times 100$ & Imutis & puaser6 & ILsast & תחתמו & 2578.74 & 251.50000 \\
\hline mind & סבתבונו & 17200200 & $\operatorname{xos} 20.90$ & "Lotats & ivis.n & sesecess & $\operatorname{sansex} 6$ \\
\hline Maded Con & 175000 & 1000018s & . & $4 \times a r$ & 4510 & .12824 & ग125sen \\
\hline Tan & $8124=8.80$ & 20009000 & (0) & 8160787 & $=0$ & $\operatorname{sen} 5.80$ & $007372 \pi$ \\
\hline \multicolumn{8}{|l|}{ Bate 13} \\
\hline Domad & cosenes & ข.กอก & 18LJIS.4L & $\operatorname{sen} \Omega$ & thoner & 0.0000 & $10 x \operatorname{sos}$ \\
\hline Exw & 10.012 & $x, 412 \pi$ & esis.os & 1500.10 & zalesil & 12000.98 & S7.718ss \\
\hline 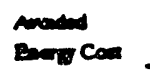 & . & 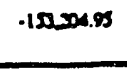 & . & הNox & ملعد & 120240 & חמשגונ. \\
\hline Tow & 8100.0410 & "MANAS & $\cos 2 \pi x$ & sizsides & suaras & $\sin 2 \pi x$ & Despess \\
\hline 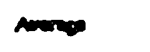 & 811400040 & Brosigs! & boxsuls & Hrovess & sumen & Matass & onsist.rs \\
\hline manen & & & & & & & manas \\
\hline
\end{tabular}




\section{Section Vr: Electronic Ballasts vs High Efficiency Core \& Coil Ballasts}

Tueson Electric Power Company will not include bigh-efficiency core and coil ballasts as part of the Retrout Commercial and Industrial Lighting Efricieacy Program. Due to the Federal ballast law effective April 1, 1990, inefficient core and coil ballasts can no longer be sold by ballast manufacturers - therefore, they are becoming less readily available to customers. Even if customers decide not to participate in the program, as old ballasts fail, they must be replaced. At the very least, they will be replaced with an energy-efficient core and coil ballast. As a result, TEP will gain the benefit of this increased efficiency without providing a financial incentive. Altbough, the demand reduction will not be obtained ir.mediately, TEP is not in need of immediate demand reduction and this decision will belp minimize the potential for "free riders."

Some currentty available electronic ballast designs do not sufficiently limit total barmonic distortion for some applications. Therefore, by not rebating high-efficiency core and coil ballasts, there is some concern that the rebate program could result in harmonics-related problems. Due to this issue, onty ballasts with total harmonic distortion (THD) of $20 \%$ or lower will qualify for a rebate. For those customers still concerned with THD, the hybrid ballast will also be eligible for a rebate.

Since clectronic ballasts are in such demand, their prices are very high. There was some concern that by limiting the rebates to hybrid and electronic ballasts, we would limit the number of customers able to participate in the program. However, in talking with customers, distributors and lighting contractors, electronic and hybrid ballasts are available at reasonable prices if customers sbop around. At present, lighting contractors are proving successfully to customers that it is cost effective to utilize bybrid and electronic ballasts even without a rebate.

The following simple payback analysis utilizes individual ballast prices as shown:

\section{Grainger}

Quotes for Advance ballasts were requested based on purchasing 30 ballasts. A lower price can be negotiated oa an individual project basis for larger quantities.

Ballast Type

Energy Efficient Core \& Coil (Mark III)

Hybrid (Powerkut)

Electrovic

\begin{tabular}{cc} 
VendorPrice & TEP Rebate \\
\hline$\$ 17.94$ & none \\
$\$ 30.51$ & $\$ 9.87$ \\
$\$ 41.22$ & $\$ 12.08$
\end{tabular}

Ne: Cost to

Customer

$\$ 17.94$

$\$ 20.64$

$\$ 29.14$

\section{DECA (Lighting Consultant)}

DECA uses primarily EBT ballasts due to the low total harmonic distortion of $20 \%$. These approximate prices are available to customers of DECA.

\section{Ballast Type}

Energy Efficient Core \& Coil

Electroaic

$\begin{array}{cc}\text { VendorPrice } & \text { TEP Rebate } \\ \text { S19.00 } & \text { none } \\ \$ 28.00 & \$ 12.08\end{array}$

Kino Hospital researcbed ballasts before retrofitting the facility. They decided on the Valmont Optimizer (a hybrid ballast) to minimize the chance of problems due to harmonics. The bospital obtained these ballasts at a very reasonable price of $\$ 1 t .00$ each tbrough a state contract with Arizona Wholesale. If TEP's rebate progiam bad beea implemented at the time, the aet cost to Kino Hospital after the rebate would bave been \$4.13 per ballast. 
ANALYSIS SUMMARY

\begin{tabular}{|c|c|c|c|c|c|c|}
\hline $\begin{array}{c}\text { Ballast } \\
\text { Type }\end{array}$ & Cost & Rebate & $\begin{array}{c}\text { Simple } \\
\text { Payback } \\
\text { period } \\
\text { Years)(1) (2) }\end{array}$ & $\begin{array}{c}\text { Watts } \\
\text { Reduced }\end{array}$ & $\begin{array}{c}\text { kWb } \\
\text { Reduced } \\
\text { Annuallyt }\end{array}$ & $\begin{array}{c}\text { Life of } \\
\text { Ballast } \\
\text { (Years) }\end{array}$ \\
\hline $\begin{array}{c}\text { Advance } \\
\text { C\&C }\end{array}$ & $\$ 17.94$ & None & 25 & 27 & 84 & $>15$ \\
\hline $\begin{array}{c}\text { Advance } \\
\text { Hubrid }\end{array}$ & $\$ 30.51$ & $\$ 9.87$ & 2.1 & 37 & 115 & \\
\hline $\begin{array}{c}\text { Advance } \\
\text { Electronic }\end{array}$ & $\$ 11.22$ & $\$ 12.08$ & 2.7 & 40 & 126 & 25 \\
\hline $\begin{array}{c}\text { EBT } \\
\text { C\&C }\end{array}$ & $\$ 19.00$ & None & 2.6 & 27 & 84 & $>15$ \\
\hline $\begin{array}{c}\text { EBT } \\
\text { Electronic }\end{array}$ & $\$ 23.00$ & $\$ 12.08$ & 15 & 40 & 126 & 25 \\
\hline $\begin{array}{c}\text { Valmont } \\
\text { Hubrid }\end{array}$ & $\$ 14.00$ & $\$ 9.37$ & 0.4 & 37 & 115 & \\
\hline
\end{tabular}

\section{Notes}

1. Payback includes savings due to cooling reduction.

2. Payback, watts reduced and $\mathrm{kWh}$ saved are based on replacing a standard magnetic ballast and $2-10$ watt lamps. Energy cost is 6.0421 centsikWb.

3. Watts and $\mathrm{kWh}$ reduced are approximate.

4. KWh reduction estimate is based on 12 bours/day or 3120 bours/year. 


\section{APPENDIX B}

\section{Retrofit Rebate Schedule}

The rebate amounts are based on the estimated $\mathrm{kW}$ reduction resulting from replacing existing components which do not meet Federal efficiency minimum requirements with components that exceed Federal requirements. In the case of devices such as occupancy sensors, an engineering estimate of the effect on demand is used. Rebates are only for demand reduction occurring during system peak which is directly attributable to lighting load and do not include reductions attributable to decreased cooling load. Rebate amounts are based on the annualized avoided cost per $\mathrm{kW}$ per year of a $75 \mathrm{Mw}$ combustion turbine. The present value of the demand savings for each item (over an assumed $n$ year life) was calculated to determine the individual rebate amounts. The assumed life for each item is as follows:

$\begin{array}{lc} & \text { LIFE } \\ \text { Fluoresceat lamps } & 3 \text { years } \\ \text { Ballasts } & 10 \text { years } \\ \text { Specular Reflectors } & 10 \text { years } \\ \text { Fluorescent Fixture Replacement } & 10 \text { years } \\ \text { Exit Signs } & 10 \text { years }\end{array}$

Rebate amounts are set at a level not to exceed the replacement item's material cost. As the program progresses and more customer information is available, rebate levels will be set so that the customer payback period is approximately one year. These amounts were compared with rebate amounts from other utilities to determine whether they were in a reasonable range as compared to other cost effective incentive programs. For a list of wholesale and retail lighting product distributors and lighting contractors, reter to Appendix $C$.

In most cases the amount is stated on a per unit basis to facilitate rebate computation by the customer and record-keeping by the Company. Ligbtiog couservation measures not listed bere can be submitted to TEP for review and approval.

Fuorescent lamps

\begin{tabular}{|c|c|c|c|}
\hline Existing & \multicolumn{2}{|c|}{ Replacement } & Rebate \\
\hline 40-W Fluorescent & \multicolumn{2}{|c|}{ 32.W Fluorescent } & $\$ \overline{s 1.00 / \text { tube }}$ \\
\hline 40-W Fluorescent & \multicolumn{2}{|c|}{$3+W$ Fluorescent } & So.75/tube \\
\hline 34W Fluorescent & \multicolumn{2}{|c|}{ 32-W Fluorcscedt } & S0 $38 /$ tube \\
\hline 75.W Fluoresce at & \multicolumn{2}{|c|}{ 60-W Fluorescent } & \$1.s8/tube \\
\hline 110-W Fluorescent & \multicolumn{2}{|c|}{ 95.W Fluorescent } & S1.s8/tube \\
\hline Incandescent & \multicolumn{2}{|c|}{ Compact Flunrescent } & Rebate \\
\hline $25 W$ & & $\left(8 W^{*}\right)$ & s2.13/tube \\
\hline $40 W$ & $7 w$ & $\left(9 \mathrm{~W}^{\circ}\right)$ & S3.89/tube \\
\hline $40 \mathrm{~W}$ & $9 \mathrm{~W}$ & $\left(10 W^{\circ}\right)$ & S3.76/tube \\
\hline $60 \mathrm{~W}$ & $13 W$ & $\left(16 W^{\circ}\right)$ & s5s2/tube \\
\hline $75 \mathrm{~W}$ & $18 \mathrm{~W}$ & $\left(23 W^{\circ}\right)$ & S6.52/tube \\
\hline $100 \mathrm{~W}$ & $26 \mathrm{~W}$ & $\left(33 W^{\circ}\right)$ & S8.40/tube \\
\hline
\end{tabular}

- Inclūides Ballast watts 
Ballasts

\section{Existing \\ Standard Fluorescent \\ Standard Fluorescent \\ Standard Fluorescent}

- Magnetic Heater Cutout
Beplacement Rebate

Hybrid* $\$ 9.87$

Electronic $\$ 12.08$

Dimmable Electronic $\$ \$ 1835$

Ballasts must not exceed a total harmonic distortion of $20 \%$. Ballasts shall be " $A$ " sound rated.

Note: Replacements based on operating (2) 34-W energy-saving lamps. Standard Ballast Input 96 Watts.

Delamping

\$13.42/40-W tube removed

S11.4034-W tube removed

$\$ 25.17775$-W tube removed

\$36.91/110.W tube removed

If delamping is the only conservation measure taken, customers will be required to disconnect and remove any unused ballasts from the fixture.

Specular Rellectors

$\$ 13.42 / 40-W$ tube removed

S11.40ß34-W tube removed

\$25.17775.W tube removed

\$36.91/110-W tube removed

Fixtures

Existing

Standard $4 \mathrm{ft}$. T- 12

(4 lamps 2 ballasts)

184 Walts
Replacement

4 lamp T 8 with

an electronic ballast

113 Walts

$\$ 23.83$

\section{Controls}

$$
\text { Timers }
$$

Rebate

\$10.33

Occupancy Sensors

$\$ 1033$

Exit Sign (Fluorescent, LED,

Electroluminescent

\section{Existing}

$40 \mathrm{~W}$

$40 \mathrm{~W}$

$40 \mathrm{~W}$

$60 \mathrm{~W}$

Replacement
$2 \mathrm{~W}$
$6 \mathrm{~W}$
$7 \mathrm{~W}$
$9 \mathrm{~W}$

69
Rebate

S12.i5

\$11.+1

$\$ 11.07$

S17.11 


\section{EID Retrobits}

Specific indoor retrofit designs incorporating HID lamps (excluding Mercury Vapor) will be reviewed individually. A rebate will be determined based on the amount of current avoided cost.

NOTE: A minimum level of $\$ 100.00$ in rebates is required to qualify for participation in the program.

\section{Rebate Procedure}

1. A request for a retrofit rebate will be handled through the customer's Account Executive. Any new construction lighting schedules will be reviewed by the lighting specialist in Technical Support Services with the rebate amount determined individually.

2. For new construction, plans will be examined to determine the scope of the project and to what extent the lighting system exceeds Federal minimum requirements.

3. For existing construction, an on-site visit will be made to assess existing facilities to develop before and after" lighting schedules. Ballast inspection will also be done at this time to deternuine whether they contain PCBs. If so, it will be noted that special disposal of these ballasts will be necessary.

4. Rebate payments will be contingent upon proof of disposal of all old lamps and ballasts. Proof of proper disposal of PCB ballasts will be required if they are not disposed of through IEP.

5. Existing lighting systems witb ballasts manufactured before 1979 are assumed to contain PCBs and must be disposed of appropriately. Undated ballasts are assumed to contain PCBs. Customers will be given the option of disposing of these ballasts the mselves or making disposal arrangements with TEP.

6. The application form will be completed on a preliminary basis with the understanding that linal payment will be based on an examination and spot check of completed facilities.

7. The application will be adjusted, if necessary, based on as-built conditions. Customers will be required to submit original material invoices. Rebate amounts will be calculated from these invoices.

8. A request for voucher will be completed.

9. Delivery of the rebate check will be scheduled after the customer completes the customer participation (Iree rider) survey.

10. The completed check may be basd-de livered or mailed. 


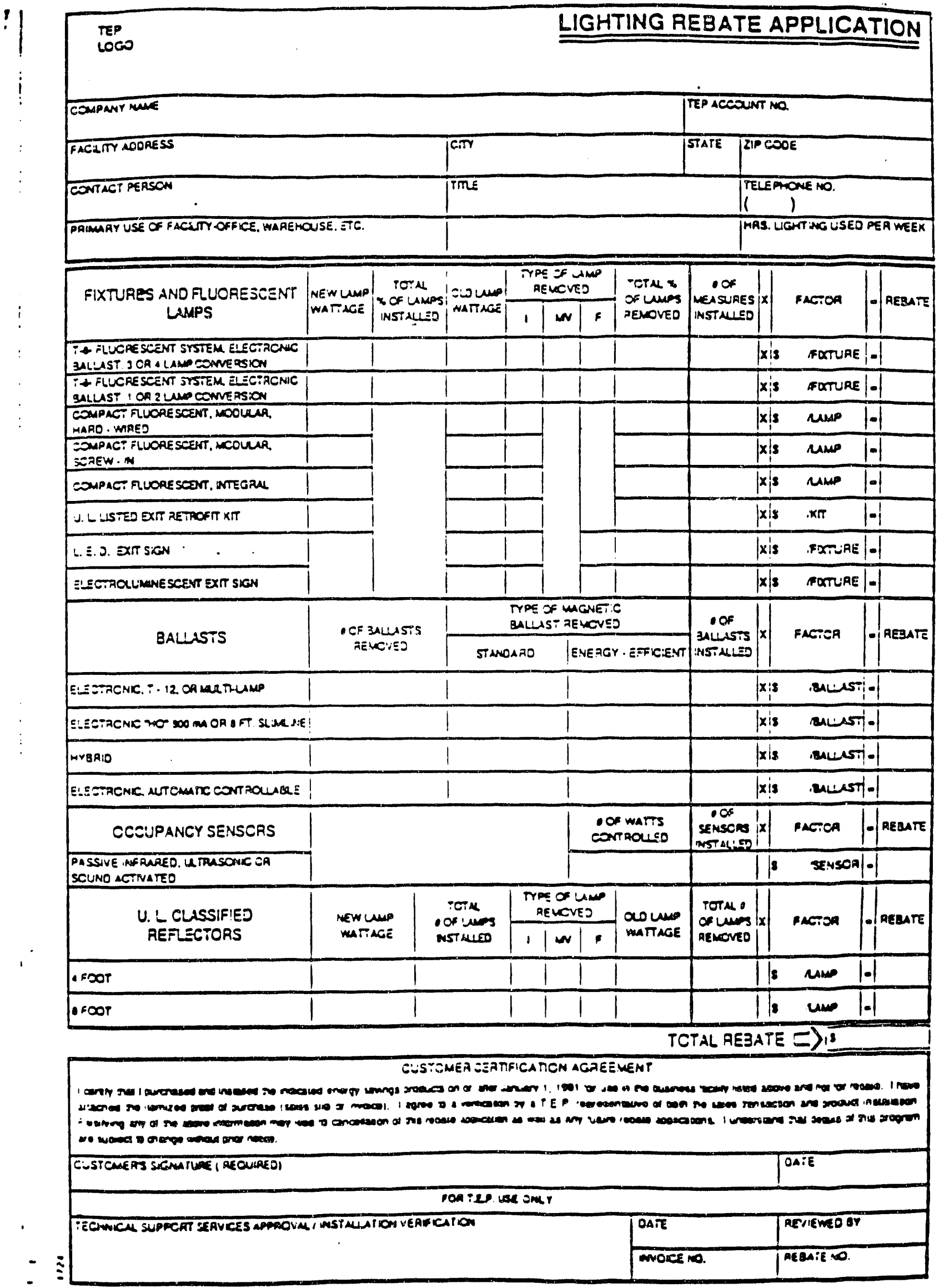




\section{APPENDIX C}

\section{Distributor and Contractor List}

A referal list of wholesale and retail lighting product distributors and lighting contractors will be maintained by the Electric League of Arizona. To be included on the referral list, distributors and contractors must have:

A. Minimum of two years of satisfactory performance as a licensed and bonded firm in the lighting industry is Arizona.

B. All necessary licensing in active stalus; satisfactory record with the Registrar of Contractors and/or Technical Board of Registration and the Better Business Bureau.

C. Completion of Electric League approved training requirements. (Not required for distributors).

D. Compliance with signed Pledge of Performance.

E. Membership in good standing in the Electric League of Arizona.

F. Record of tinancial accountability.

\section{Disclaimer}

TEP does not recommend any particular manufacturer's equipment, any distributor or contractor. TEP encourages customers to uiilize the referral list maintained by the Electric League of Arizona however, this should not be considered an eadorsemeat of these distributors, contractors or the products they sell/use. TEP does not imply that contractors aot shown on this list are in anyway incompetent. Additionally, TEP does not imply that the produets used by the contractors or sold by the distributors not listed are in anyway defective.

NOTE: To develop an unbiased list of distributors and contractors, a letter and questionnaire will be sent to all local distributors and contractors. If the recipient of the letter wishes more information on how to be included on the Electric League's list, they must complete the questionnaire and return it to the Electric League. A copy of the letter and questionaaire may be found on the following pages. TEP will work with the Electric League of Arizona to develop a trade ally organization of qualified contractors and equipmeat suppliers. 
January 15, 1992

Business Name

Address

City/State/Zip

Dear Lighting Specialist:

Tucson Electric Power Company is very pleased to announce our Commercial and Industrial Lighting Efficiency Program. This program will provide monetary incentives to customers who are interested in retrofitting their existing lighting system with a more energy-efficient one. Initially, TEP will offer rebates on energy-efficient fluorescent lamps, ballasts, specular reflectors, exit signs, compact fluorescents and occupancy sensors. Products may be added or deleted from the rebate list at any time.

As a service to our customers, a list of businesses where these energy-efficient products are available and a directory of contractors/consultants who promote energy-efficient products and designs will be maintained by the Electric League of Arizona. If you would like your business to be included on this list, please complete the attached questionnaire and return it to TEP by For your information, a copy of the lighting program and information on how to be included on the Electric League's referral list will be sent to you upon receipt of your completed questionnaire. We look forward to working with you.

Sincerely,

Charlotte Otero-Goodwin

Electrical Engineer

Conservation and Load Management 


\section{LIGHTING PROGRAII QUESTIONNAURE}

Busizess Name

Address

Phone

Contac: Person

- Do you wish your business to be included on the Electric League's distributor and contractor list?

$$
\text { Yes }
$$$$
\text { No }
$$

- Under which category would you like to be included?

Distributor

- Are you a wholesale distributor?

- Are you a retail distributor? Contractor

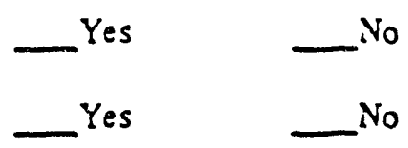

- What brand(s) of lamps do you carry? - Sylvania

$$
\text { _Pbiijps }
$$$$
\text { - Ostam }
$$$$
\text { _Geseral Electric }
$$

- Other

- What brand(s) of ballases do you corry?

- Advance

- EBT

_Valmont

_Liversal

- Otber

\section{P'ease check the groduc: s vou carrv}

Euorescent Lames

32. Wall

$3+W_{218}$

-60.Watt

-95.Wall

Otber eaergy efficieat size (specify)
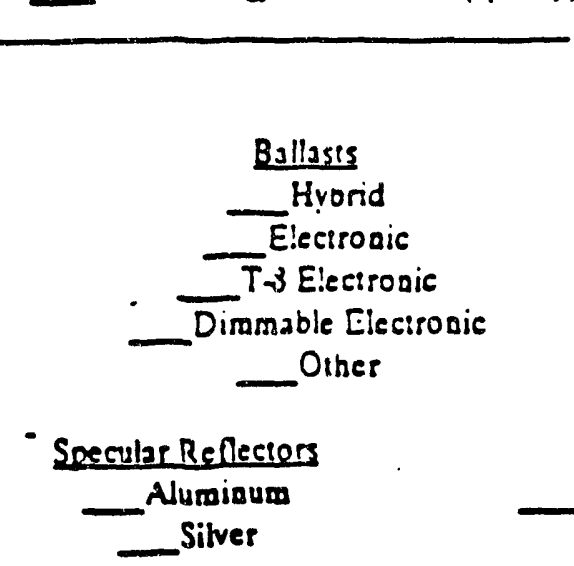

Ballasts

Hrorid

Elecironic

T-3 Electronic

Dimmable Electrodic

Other

- Specular Reflecions

Silver

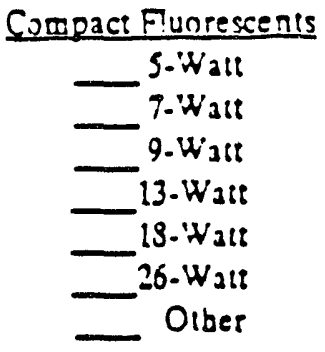

Erit Sim Conversion Kirs

2-2. vistt

6. W31t

i.'tials

9. Walt

Otber

Qceupaney Sensors

lafrared

thamp T-3 with an

electronic ballass ultrasonic 


\section{APPENDIX D}

\section{TEP LIGHTING PROGRAM EDUCATION AND PROMOTIONAL MARKETING PLAN}

The Educational and Promotional Plan will give special emphasis to educational programs that raise customer awareness of the benefits of energy-efficient lighting programs. Program information will be distributed by TEP staff through seminars, personal contact, news media interviews, and public speaking appearances.

The marketing plan consists of five major components: 1) collateral materials, 2) direct mail, 3) communications and public relations, 4) advertising, and 5) trade press reprints. The collaterai materials include application and rebate forms: a "generic" brochure that describes the program basics; and a lighting glossary. For customers who are unable to qualify for participation in the program, self-belp materials will be provided so they can implement small conservation lighting projects.

A direct mail piece, consisting of a personal letter and the generic brochure, will announce implementation of the program and identify the qualification requirements. The initial mailing will be aimed at a list of key customers from all commercial rate classes; product manufacturers, vendors and suppliers: trade allies and other professional organizations; and purchasing agents at key wholesalers and retailers. The effectiveness of a bill insert will be analyzed.

Advertising will build program awareness aad prompt customers to coatact TEP for information. A co-op advertising program with manufacturers and suppliers will be evaluated. AD opening news conference, news releases, and feature story proposals will be the key to the communications. The Company newsietter will be used to increase employee knowledge of the program.

Extemal communications will focus on meeting with product manufacturers, vendors and other trade allies through a series of educational seminars. Target groups include the Building Owners \& Maintenance Association, the Tucson Chamber of Commerce, the Electric League of Arizona and the SBA. Staff members will also make personal contact with cusiomers. 


\title{
APPENDIXE
}

\author{
Commercial and Industrial New Construction Lighting Efíciency Program
}

Just as utilities actoss the country have found that retrofit lighting programs are a proven means of reducing electrical energy demand, utilities also realize that new business efficient lighting programs bave the potential to retard load growth. However, since many new business owners are concerned with the initial cost of a construction project, they rarely look abead at their potential energy costs. Even so, utilities bave found that the best time to entice a business into implementing a conservation measure is before construction, when the initial cost to implement the measure is much less than the retrofit cost would be a few years later. In this way, both the customer and the utility beneat in the long run. Tueson Electric Power Company views this type of program as a beneticial situation for both parties and therefore will implement a pilot Commercial and Industrial New Construction Lighting Efficiency Program.

\section{Rebate Schedule}

The rebate amounts are based on the $\mathrm{KW}$ reduction resulting from utilizing components which exceed Federal minimum requirements. In the case of devices such as occupancy sensors, an engineering estimate of the effect on demand is used. Rebates are only for demand reduction directly attributable to lighting load and do not include reductions attributable to decreased cooling load. Any new designs incorporating energy saving options not included on this list will be reviewed on a individual basis. A rebate will be determined based on the amount of TEP's avoided cost. To qualify for the program, all ballasts shall be fully electronic or hybrid (combination of electronic and core and coil). All Extures shall be installed indoors, and operate during the 10:00 AM - 10:00 PM summer "peak" period.

Eluorescent Firtures

Upgrade from 4-kamp fixture with energy efficient ballasts to:

T-8 fixture, 432 -Watt lamps

T-8 cixture, 3 32-Watt lamps

T-8 ixture, 232 Watt lamps

Upgrade from 3-lamp fixture with energy effrcient ballasts to :

T-8 tixture, 3 32-Watt lamps

T-8 Eixture, $232-$ Watt lamps

Upgrade from 2-lamp, 75-watt fixture to:

1'x8' Exture, 260 Watt lamps

1'88' Eixture, 4 32.Watt lamps

Controls

Dimmable electronic ballast (T-\& only)

Occupancy Seasors

Timers

\begin{tabular}{c} 
Compact Fluorescent \\
\hline $5 W$ \\
$7 W$ \\
$9 W$ \\
$13 W$ \\
$18 W$ \\
$26 W$
\end{tabular}

Exit Sirns

LED 8.Watts or less

Electroluminescent 2.Watts or less
Rebate

$\$ 19.13$

$\$ 28.69$

$\$ 38.25$

$\$ 14.26$

$\$ 23.73$

$\$ 17.79$

$\$ 15.43$

$\$ 6.27$ additional

$\$ 10.00$

$\$ 10.00$

$\$ 2.13$

$\$ 3.89$

$\$ 3.76$

$\$ 5.52$

$\$ 6.52$

58.10

Rebate

- $\$ 11.00$

$\$ 12.75$ 


\section{Participant Selection}

All new business customers who fall under the Rate 10,12,40,13 and 14 categories will qualify for the rebate program. The customer will be required to submit a copy of the new facility's lighting design for approval. Once the design is approved the customer will be considered eligible for funds upon strict compliance with the program guidelines. After the construction is complete, the customer must contact TEP to schedule a post-construction audit. Once it is verified that the approved design has been installed, the customer will submit a copy of the approved product invoice. The rebate will be calculated based on the quantities appearing on the invoice. The rebate check will be delivered by a TEP Account Executive or Energy Auditor.

\section{Budget}

Tit: sudget for this program is summarized on page 4.

\section{Program Goal}

The objective of the Commercial and Industrial New Construction Lighting Efficiency Program is to retard load growth and promote energy conservation.

\section{Program Evaluation Procedure}

Since this is a new construction program, there are no load measurements which can be taken before the conservation measure is implemented. Therefore, this evaluation procedure will be based on calculating the load for the system the customer would have implemented without the rebate and comparing it with the actual system load. The base system prior to a rebate will be assumed to have consisted of components meeting Federal minimum standards. The differeace will be used as the actual impact of the program.

\section{Estimated System Impact}

The direct system impact of the Commercial and Industrial New Construction program was estimated using TEP's projections of commercial and industrial load growth's. The impact was estimated for the years 1991 to 1995 , assuming the pilot program or an official program extends past the year 1993. The estimated direct load impact is shows on the following table. 
New Construction Lighting Program Load Impact

\begin{tabular}{|c|c|c|c|c|}
\hline Year & $\begin{array}{l}\text { Estimated } \\
\text { Commercial } \\
\text { Industrial } \\
\text { Load } \\
\text { Growth (Mw) }\end{array}$ & $\begin{array}{c}50 \% \\
\text { Encouraged to } \\
\text { Participate (Nw) }\end{array}$ & $\begin{array}{c}40 \% \\
\text { Due to } \\
\text { Ligbting (M/w) }\end{array}$ & $\begin{array}{c}\text { "34\% } \\
\text { Direct } \\
\text { Reduction (Mw) }\end{array}$ \\
\hline 1991 & 39.69 & 19.85 & 7.94 & 2.7 \\
\hline 1992 & 15.38 & 7.69 & 3.08 & 1.05 \\
\hline 1993 & 22.47 & 11.24 & 45 & 1.53 \\
\hline 1994 & 20.18 & 10.09 & 4.04 & 1.37 \\
\hline 1995 & 28.29 & 14.15 & 5.66 & 1.92 \\
\hline
\end{tabular}

- $40 \%$ from Competitek, Rocky Mourtain Institute, page 15.

- $\quad 34 \%$ is the approximate demand savings on one standard + lamp firture with high efficiency $C$ \& $C$ ballasts upgraded to a 4-lamp T- 8 fixture with electronic ballasts. (Standard fixture approximately 170 watts input, T. 8 fixture approximately 113 watts input) 


\section{BIBLIOGRAPHY}

(1) Competitek, 1988 Rocky Mountain Institute, Lighting, page 15.

(2) Response of TEP to R14-2-703 Utility Reporting Requirements of the ACC Resource Planning Rules, April 1, 1991, page 65.

(3) TEP's 1990 Avoided Cost Filing.

(4) TEP Rate Case, test year ended June 1990.

(5) Distribution Planning Department's Projected Commercial and Industrial Load Growth Report. 


\title{
SOURCES OF LIGHTING INFORMATION AND SERVICES
}

\section{AMERICAN PUBLIC POWER ASSOCLATION (APPA)}

$\frac{\text { tilles }}{21}$

2301 M Street, N.W., Washington, D.C. 20037

(202) 775.8300

Membership Association of Local Community-Owned Electric

Systems/Publications/nformation and Library Services/Standing Committees

Member Services

Governmental Relations

Energy Services Exchange

Utility Education Courses

Standing Committees

Member Data Services

Technical and General Library

Major Publications

Washington Alert (government relations bulletin)

PowerManager (software library)

Public Power Weekly (newusletter)

Puolic Power (magazine)

Public Power Quarierly Communicator (communications newsletter)

$D E E D$ Digest (technical aricies)

Human Resources Report (newislester)

Publication Subject dreas

Member Services

Bill Stuffers

Communiention and Consumer Services

Management Aids and Manuals

\section{COMPETITEK}

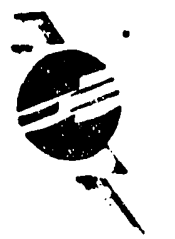

Rocky Mountain Institute, 1739 Snowmass Creek Road,

Snowmass, CO 81654.9199

(303) 927.3128 or .3851

Nonprofit, Proprietary ATiliate of Rocky Mountain Institute/Research, Information Dissemination

\section{ELECTRIC POWER RESEARCH INSTITUTE (EPRI)}

\author{
3412 Hillview Avenue, P.O. Box 10412, Palo Ato, CA 94303 \\ ERi- (415) 855-2000
}

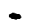
Research Arm of the Electric Power Industry/Extensive Publications/
Publications Free to Members, Fee Otherwise 


\section{Special Information}

Research Reports Center. (415) 965-4081

Technical Information Specialists (Research Programs): (415) 855-2411

Information Hotline: (415) 855-2411

Sample Publications

EPRI Guide: Technical Reports Published January 1987 • May 1989

Lighting Handbook for Utilities (EPRI EM-423, Apr. 1986)

Personal Computer Software for Lighting Design and Analysis (EPRI E.M-5463, Oct. 1987)

Survey of Utility Lighting Programs (EPRI E.M.5093, Feb. 1987)

\section{Publications Database}

EPRI Technical Information Specialists can complete database searches on key words. Printouts provide abstract, background, object, approach, and key points.

\section{ENERGY USER NEWS (EUN)}

Enernitiver Fairchild Publications, A Division of Capital Cities, Inc.

7 East 12th Street, New York, NY 10003

Subscription: $1-800-247-8080$

Major Periodical, Published 12 Times'a Year (annual subscription, \$66.00)-Regular Feature Articles on Lighting and Many Other Energy Related Areas/Energy News"Product Guides" Feature Categorical Comparisons On Featured EnergyRelated Products and Services/Scoreboard" Comparisons of Selected L"tility Programs

Special Reports \& Product Guides

JAVUARY 1989 - SPECLAL REPORT:

Product Guide: Fluorescent Reflectors

FEBRUARY 1989 - ASERAE ISSUE:

Cutting Air Conditioning Costs With Lighting Retrofits

Product Guide: Fluorescent Lamps

MARCH 1989 - UTIIITY SERVICES:

Utility Rebate Scoreboard/Case Study Utility Incentives

Articles: The lser Scrools: Training in Controls and Lighting". "New Lighting Labs at G.E.. Philips, and GTE Showease Efficient Lumps", and The Distributors' Lighting Centers"

Product Guide: Oceupancy Sensors 
APRIL 1989 - COMNLERCIAL BUIIDLNG, CEAINS AND FRANCHISES

Product Guide: Lighting Services

MAY 1989 - LIGETING WORLD (NEW PRODUCTS AT N.Y. EXPO)

Architects and Designers' Guide to Energy-Efficient Lighting/Buying Aesthetics and Security with Energy Savings/User Trends: Who's Buying What and Why/The Marketing and Servicing of the Lighting System Concept/New Products at Lighting World

Product Guides: Ballasts/Lighting $\hat{C}_{\text {ontrols } / \text { Lighting Services }}$

JULY 1989 - ELECTRIC ENERGY STRATEGIES:

Low-Wattage Lighting

Product Guide: Compact Fluorescents

SEPTEMIBER 1989 - COMLMERCLAL AND INDUSTRIAL BUILDLVGS:

Utility Rebate Guide and Scoreboard Update

OCTOBER 1989 - WORLD ENERGY CONGRESS SHOW ISSUE:

Lighting Controls

NOVE.MBER 1989 - LIGHTING:

Ballasts/Reflectors/Controls/Occupancy Sensors/Lamps/Current Limiters and Security Lighting. Lamp Product Showease: Current Specialty Lamps iorm Compact Fluorescents to Metal Halide and Sodium

Product Guide: Lighting Contrals

\section{ILLUMINATING ENGINEERING SOCIETY OF NORTH ANERICA (IESNA)}

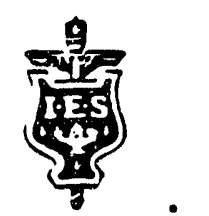

345 East 47th Street, New York, NY 10017

(212) $705-7926$

Technical Society for Lighting Industry/Set Standards and Testing Guidelines

\section{Major Bandbooks/References}

IES Lighting Handbook Application Volume (1987)

Includes: Illuminance Selection Table/Lighting Controls/Power Budget Limits/Lighting Spaces Regarding Visual Display Terminals VDTV/Lighting Design Energy Management/Lighting Economies Applications: Offices' Edueational Faeilities/nstitutions/Public Buildings/Merchandising Areas/Over 25 Industrial Areas/Roadway Lighting/Aviation Lighting/ Transportation/ AdvertisingUnderwater/Effects of Radiant Energy/ Searchlighted Residences Theatre and Television/Photographid Ourdoor Applieations/Sports and Recteational Areas

IES Lighting Handbook Reference Volume (1984) 
Includes: Comprehensive Dictionary of Lighting Terminology/ndex-

Complete Sections on: Daylighting/Luminaires/Light Sources/Lighting

Calculations/Methods: Measurement of Light and Other Radiant

Energy/Light \& Optics/Light \& Vision/Color

\section{IES Lighting Ready Reference}

Includes: Definitions and Conversion Factors/lluminance Recommendations and

Lamp Tables/Energy Management/Survey Procedures/Cost Analysisicalculation

Data

LiteBase (Lighting Information Electronic Database)

A lighting information index/database, BETA TEST version available in December 1989. Call IESNA for details, (212)705-7926.

Includes Information from These Sources:

The Journal of the IESNA (began 1971)

The articles from Ligh:ing, Design and Application (began 19:1)

Articles from Illuminating Engineering magazine (1906-1971, 10000 articles;

Recommended Practices (RP's) of the IESN.A

Lighting Measurements Guide (L.l's) of the IES.NA

Committee Position (CP's) of the IES:NA

Other Transactions of the IESN

Publications of the Commission Internationale De I'Eclairage (CIE)

Domestic magazine articles (Architectural Lighting, Lighting

Dimensions, etc.)

Foreign magazines in the field of lignting from: Russia, China, Korea, Australia, Great Britain, Sweden, etc.

Books related to the Lighting field

Computer programs in lighting

Audio/Visual materials (including slides)

Newsletters from related associations/societies/businesses

\section{Searches By:}

Index Key (Primary, Secondary, Tertiary)

Author

Time Period

Type of Source (journal, magazine, book, etc.)

By a combination of the above items.

\section{Periodicals}

Lighting Design + Application (monthly magazine)

Journal of the IES (semi-annual)

Subject Areas for Other Publications

Lighting Education

Recommended Practices

Lighting Encrby Management

- Committee Reports

Lighting Measurements

Lighting Books (specialized areas) 


\title{
Local IESNA Section Contacts
}

There are over 100 local sections nationwide. To obtain information on the section office nearest your location, contact the Department of Member Services in New York at (212) 705-7914.

\section{LAWRENCE BERKELEY LABORATORY (LBL)}

回

No. 1 Cyclotron Road, Berkeley, CA 94720

(415) $486-4000$

National Laboratory/Part of Research is Energy-Related/Research

Contracts from Federal Govemment, States, Private Organizations

Publication Areas

Lighting Systems Research, address as above - Bldg. 46-125

(415) 486-7077

Window and Daylighting Research, address as above - Bldg. 90-3111

(415) 486-5605

\section{LIGHTING RESEARCH INSTITUTE (LRI)}

\author{
345 E. 47th Street \\ New York, NY 10017 \\ (212) 705-7511
}

Research Arm of the Lighting Industry/Nonprofit Organization/Sponsor, Promote and Manage Lighting. Related Research/Assess Research . Veeds in Coordination with Related Associations: Illuminating Engineering Society of North America (IES.NA), Electric Power Research Institute (EPRI), U.S. Department of Energy (DOE), Commercial Lighting Companies, and Electric Utilities and Their Associations/Fund Research with Pooled Monies/Research and Education

Provided through affiliate organizations. For example, IESNA training modules, EPRI research reports and utility lighting demonstration projects. Mailing list keeps interested parties updated on lighting research projects and report availability.

Sample Publications

Development of Streetlighting Research Plan

- (Results of streetlighting survey, including separate findings for public electric utilities. [R] publication).

A Design for a Lighting Demonstration Module (EPRI CU.6320)

(Recommendations on how utilities can design lighting de anonstration mas. ules for personnel education and customer promotions. EF problicators, research conducted by LRI).

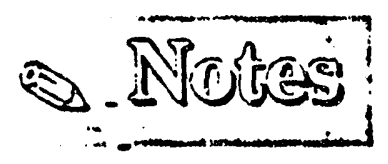




\title{
NATIONAL ASSOCIATION OF ELECTRICAL DISTRIBUTORS (NAED)
}

28 Cross Street, Norwalk, CT 06851

(203) 847.6800

Professional association for electrical distributors

Books \& Publications

A/V Caralog

Basic Lighting Manual

Commercial Lighting Marketing Textbook

Association Services \& Resources

Seminars and Workshops (Locations Nationwide, Major Cities)

Basic Lighting

Commercial Lighting Marketing

Audio/Visual Programs

Self-Study/On-the-Job Training Materials

Electrical Products Education Course (EPEC)

Certification Program

\section{NATIONAL ELECTRICAL CONTRACTORS ASSOCIATION (NECA)}

7315 Wisconsin Avenue, Bethesda, MD 20814

(301) $657-3110$

Professional association for electrical contractors

Sample Publications

\author{
Design Fundamentals for. Vonuniform Lighting \\ Toward Improved Lighting Quality \\ HID Lighting: Its Application and Benerits \\ Task Lighting Considerations \\ Office Lighting Practice \\ Luminaire Selection \& Specification \\ Lighting Energy Controls \\ Payback Benefits of Better Lighting \\ Temporary Electrical Facilities \\ Outdoor Lighting Management \\ Lighting Equipment Options for Modern Buildings
}

Also Note: Each year, the May issue of Electrical Contractor magazine features new developments in lighting products, design, and installation techniques.

Association Services

Local Chapter

Labor Relations

Industry Relations

Marketing

Technical and Training

Codes and Standards
Apprenticeship and Training

Fair Trade Practices

Government Relations

Field Service

Insurance Frograms 


\section{NATIONAI ELECTRICAL MANUFACTURERS ASSOCLATION (NEMA)}

NEMA 2101 L Street, N.W., Washington, D.C. 20037

(202) 457.8400

Standards Publication Sales: (202) 457-8474

Largest trade association in U.S. for manufacturers of products used in generation, transmission, distribution, control, and end-use of electricity.

Leading developer of voluntary standards and a clearinghouse for industry statistics and other information.

Example Standards Publications (Categories)

Fuses

Lighting Fixtures

Measuring Equipment, Electrical

Meters

(and over 60 other categories)

Lighting Publications

(See National Lighting Bureau listing)

\section{NATIONAL LIGHTING BUREAU (NLB)}

2101 L Street, N.W., Suite 300, Washington, D.C. 20037

(202) 457-8437

Lighting Equipment Division of NE.MA (National Electrical Manufacturers Association) - Marketing Group/Publications (see NEMA, this listing)

General public information on lighting/free publications/publications directory

Lighting Publications (One of Several Specialized Categories)

Getting the Most From Your Lighting Dollar (2nd Ed.)

Industrial Lighting Handboak

Lighting Energy Monagement for Colleges and Universities

Lighting Energy Manggement for Offices and Office Buildings

Lighting Energy Management in Retailing (2nd Ed.)

Lighting Your Way to Safety, Security and Savings

The NLB Guide to Office Lighting and Productivity

- The NL.B Lighting Benefits Series:

Lighting and Industrial Productivity

Lighting and Retail Sales

Lighting and Security

Performing a Lighting System Audit (Revised Edition)

Profiting From Lighting Modemization

Solving the Puzzle of VDT Viewing Problems 


\section{TRAINING SERVICES}

\section{AMERICAN PUBLIC POWER ASSOCLATION}

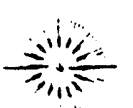

2301 M Street, N.W., Washington, D.C. 20037

(202) $775-8300$

Membership Association of Local Community-Owned Electric Systems/Publications/ Information and Library Services/Standing Committees

Training Resources

APPA Training Resource Directory

Information on Public Power Training Programs and the People Who Run Them/ndex of Training Topics, State by State Listing of Actual Programs, Alphabetical Listing of Trainers/Training Ideas and Materials

\section{GENERAL ELECTRIC}

GE Lighting Institute, GE Lighting, Nela Park - Bldg. 326, Cleveland, OH $\$ 4112$

(Attn.: Registration Office) GE Lighting Institute Program Office

1 (800) 255-1200 or FAX (216) 266-2900

Lighting demonstration and education center for end-users, distributors, contractors/ architects. Utility training.

Sample Curriculum (1989-90 Schedule):

Lighting Application Conferences:

Fundamentals of Commercial and Industrial Lighting

Industrial Lighting

Lighting for Office and Public Buildings

Modem Store Lighting

Outdoor Lighting Design

Sales Conferences:

Lighting Conference for Electrical Contractors

Lighting Management Contractors Conference

Professional and Specifier Conferences:

Consulting Engineers and Architects Conference

Contract Interior Designs

Lighting Designers

Lighting Educators

Distributor Training Conferences:

Conference for Experienced Distributor Sales Representatives

Distributor Sales Representatives

- Distributor Telephone Sales Management Seminar 


\section{GTE / SYLVANIA}

푸

GTE Products Corporation, Sylvania Lighting Center, Danvers, MA 01923

SYLVANIA (508) 777-1900

Lighting demonstration and education center for end-users, distributors, contractors/architects. Off-site training also available Nation wide. Utility training.

\section{Curriculum}

Seminars and clinics are conducted at the Lighting Center in Danvers, MA or by arrangement at locations Nationwide. The Lighting Center is used primarily for educational and business management courses for Sylvania Lamp distributor. The Lighting Center is also used when training requires sophisticated demonstration equipment.

Utilities are frequent training clients. Many training sessions are custom-tailored to the audience. Common areas include: products, applications and energy conservation.

\section{ILLUMINATING ENGINEERS SOCIETY OF NORTH AMERICA (IESNA)}

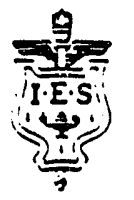

345 East 47th Street, New York, NY 10017

(212) 705-7926

Technical Society for Lighting Industry/Set Standards and Testing Guidelines

Sample Curriculum

Each of the local sections (over 100 nationally) determine priorities. To obtain information on the local section in your area call the Member Services Department in New York at (212) 705-7914.

The following is a sample listing of Autumn/Spring 1989-1990 classes.

Lighting Fundamentals (evenings, one day per week, 10 weeks)

Application of Lighting Design (four parts, one per week)

$$
\begin{aligned}
& \text { Residential Lighting } \\
& \text { Office and Retail Lighting } \\
& \text { Hospitality Restaurant and Hotel Lighting } \\
& \text { Wiring and Controls }
\end{aligned}
$$

Lighting Workshops (one day, 6 hours each)

Color and Light

Neon and Cold Cathode

Title 24 (California)

Commercial Exterior Lighting

Landscape Lighting

- Basies of Fine Lighting Design 


\section{PHILIPS LIGHTING}

For all training, contact Sherry Bachman, Lighting Center Coordinator, Lamp Information Center, 114 Mayfield Avenue, P.O. Box 3053, Edison, NJ 08818-3053

(201) $563-3600$

Lighting demonstration and education center for end-users, distributors, contractors' architects. Utility training.

Sample Curriculum (1990 Schedule):

Application Seminars:

Office Lighting Seminar

Retail Lighting Seminar

Lighting Conference on Hotel/Motel and Conferencing Facilities

Fundamentals Course:

Lighting Design and Application Worksiop

(Commercial, Industrial, Retail, and Residential)

Lighting Application Workshop for Dist-ibutor Sales Representatives

(Commercial and Industrial)

Consultant Conferences:

Lighting Conference for Consultants

Industrial Lighting Seminars

Other Courses:

Lighting Conference for Lility Representatives

Lighting Sources for the Luminaire Representative

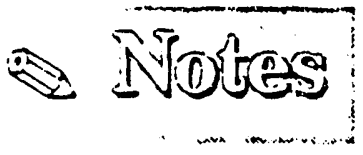




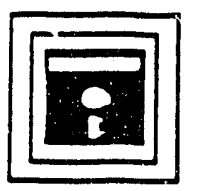

\section{SOFTWARE FOR LIGHTING ANALYSIS}

A recent review of lighting analysis software, conducted by the Electric Power Research Institute (EPRI), entitled "Personal Computer Software for Lighting Design and Analysis" (EPRI EM-5463) offers an overview of commercially available products. This report offers a succinct comparison of these products. By special permission from EPRI the following pages provide key summary information for the potential user.

If more detail is desired, the report can be obtained from the EPRI Research Reports Center, P.O. Box 50490, Palo Alto, CA 94303, (415) 965-4081. EPRI member utilities and affiliates, U.S. utility associations, U.S. government agencies, media, and some foreign organizations may receive the report free of charge, others pay a fee.

\section{Personal Computer Software for Lighting Design and Analysis - ABSTRACT}

A survey was conducted to identify and describe commercially-available, personal computer software programs for lighting design and analysis. It identified 22 pro-

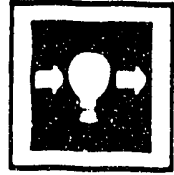

grams from 14 vendors. These programs may help electric utilities and their customers, design. ers and specifiers, and manufacturers and their representatives make better use of lighting.

The programs are divided into four cate- gories based on the method they use and their major application: Indoor Point Method, Indoor Zonal Method, Outdoor Point Method, and Economic Analysis.

The survey's major findings are provided in summary tables for each of the categories: Background and Availability, Computer Requirements, User Features, and Capabilities. These tables are supplemented by summary descriptions of each of the programs.

(p. iii)

\section{REPORT EXCERPTS}

The following pages display key tables and sections from EPRI report E.M15463. Three areas are provided:

List of Programs and Vendors;

Program Descriptions; and

List of Vendors.

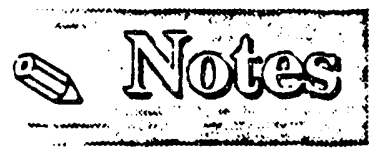




\section{LIST OF PROGRAMS AND VENDORS}

\begin{tabular}{|c|c|c|c|c|c|}
\hline \multicolumn{2}{|c|}{$\begin{array}{l}\text { A: Indoor Point Method } \\
\text { B: Indoor Zonal Cavity Method }\end{array}$} & \multicolumn{3}{|c|}{$\begin{array}{l}\text { C: Outdoor Point Method } \\
\text { D: Economic Analysis }\end{array}$} & \multirow[b]{2}{*}{ D } \\
\hline VENDOR & PROGRAM & $\mathrm{A}$ & B & $\mathrm{C}$ & \\
\hline $\begin{array}{l}\text { American Technical } \\
\text { Solutions }\end{array}$ & MCROLLX & & $x$ & $*$ & \\
\hline $\begin{array}{l}\text { Computer Aided } \\
\text { Lighting Analysis }\end{array}$ & PHOTON & & & $*$ & $x$ \\
\hline $\begin{array}{l}\text { Elite Software } \\
\text { Development }\end{array}$ & LIGHTING & & $*$ & & $x$ \\
\hline General Electric Co. & LEAP. & & & & $*$ \\
\hline $\begin{array}{l}\text { Hauser's Lighting and } \\
\text { Daylighting }\end{array}$ & L2 & $"$ & & $x$ & $x$ \\
\hline $\begin{array}{l}\text { Illumination } \\
\text { Computing Service }\end{array}$ & $\begin{array}{l}\text { ELERGY } \\
\text { DESIGN } \\
\text { PLANE }\end{array}$ & * & & $*$ & * \\
\hline Jolinko Encerprises & STLT & & & $*$ & \\
\hline Lighting Analysts & POLNT & & & $*$ & \\
\hline Lighting Technologies & $\begin{array}{l}\text { LLXENS } \\
\text { LLMEN-VICRO } \\
\text { LLXEN-POINT }\end{array}$ & - & & $*$ & $*$ \\
\hline $\begin{array}{l}\text { Marston, Kinney and } \\
\text { Associates }\end{array}$ & LITCAL & & * & & $x$ \\
\hline MC2 Engineering & E. .11 & & 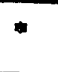 & & $x$ \\
\hline $\begin{array}{l}\text { Murray \& Gillespie } \\
\text { Computer Solutions }\end{array}$ & $\begin{array}{l}\text { MICRO-SITE-LITE } \\
\text { MICRO-COST-LITE } \\
\text { MICRO-EYE-LITE }\end{array}$ & - & $x$ & 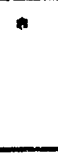 & * \\
\hline $\begin{array}{l}\text { RLH Lighting } \\
\text { Consultants }\end{array}$ & LIGHT \& EASY & & * & $x$ & $x$ \\
\hline Wilcox Engineering & $\begin{array}{l}\text { 2ONAICOM } \\
\text { FLLDWWARE } \\
\text { ROADWARE } \\
\end{array}$ & $\cdot$ & $\bullet$ & 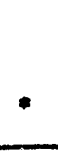 & $\begin{array}{l}x \\
x \\
x \\
\end{array}$ \\
\hline LEGEND: & $\begin{array}{l}\text { S most sophisticated } \\
\text { ogram function }\end{array}$ & & & & \\
\hline
\end{tabular}




\section{INTRODUCTION}

i

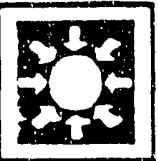

This section contains descriptions of each software package reviewed by EPRI in Report EM-5463. The reader will notice that some suppli. ers offer more than one software option.

The full addresses, telephone numbers, and contact name for each vendor is included on the last page of these EPRI report excerpts. [Editor insert].

\section{AMEKICAN TECHNICAL SOLUTIONS}

\section{"Microlux"}

This program quickly performs calculations for both indoor and outdoor applications. Point calculations are used for outdoors, and the zonal cavity method is used for indoor calculations.

The sample database provided consists of ten outdoor luminaires or the maintained footcan. dles may be determined. There is no limit on the number of rooms which can be analyzed in each run, and outputs are provided as a table for each room. These consist of a report of the input data, calculated average illuminance, and number of luminaires.

For outdoor applications, output tables consist of illuminance for each analysis plane.

\section{COMPUTER AIDED LIGHTENG ANALYSIS}

\section{"Photon"}

PHOTON is a graphically oriented program that provides many features ncrmally associated with more expensive computer aided design systems (C.AD). With the optional digitizer. inputs can be entered by tracing over a drawing or blueprint with a mouse. By pressing the appropriate buttons, luminaires can be placed and aimed as desired.
The program features a "message system" which guides the user through the necessary execution steps. During recalculations, the program saves time by only calculating changes for the latest additions.

The supplemental data manager program allows creation or editing of photometric data ir. the IES standard or the program's own format. Photometry may be viewed either graphically or - digitally. Roadway modeling is speeded up by allowing points to be defined by drawing a sin. gle line segment. The lines may be defined in all three dimensions, so that three-dimensional surfaces can be modeled.

Interior spaces can be rnodeled with interreflected light. Each room surface can include up to 100 different reflective panels.

The deluxe printout allows designs to be printed in plan and/or perspective view, and features other graphic enhancements such as shading and a compressed mode for quicker printing.

\section{ELITE SOFTWARE DEVELOPMENT}

\section{"Lighting"}

In addition to performing zonal cavity calcula. tions for several rooms at a time, this program can also provide economic analysis of three alternative lighting systems for a given room. The data in put features full-screen capability, and supports a color monitor. The user's manual is very comprehensive, and includes instructions for verifying the results using the IES Reference Volume. This may be helpful for designers who are unfamiliar with the zonal cavity method.

The economic calculations include the costs of installation, cleaning, relamping, lighting, and lighting heat removal. A total life-cycle cost for each is system is produced, based on a userdefined system life.

Four different types of reports are available: project input data, luminaire requirements, user-defined luminaire schedule, and energy economics. These may be output to either the sereen or printer. Each report is customized 
with the user's company name.

Updates to the program are periodically avail-

able for a small fee (usually $\$ 10$ to $\$ 50$ ).

\section{GENERAL ELECTRIC COMPANY}

\section{"Leap"}

The Lighting Ecunomic Analysis Package consists of three programs. COST compares costs of different lighting systems, RETRO compares the costs for replacing lamps and ballasts with more efficient equipment, and PLAN determines the optimum relamping and/or cleaning schedules.

A database of 300 lamp/ballast/uminaire combinations is provided with the package, for use with PLAV. Annual updates are also available for $\$ 50$ each.

Input data gathering is made easier through the use of data collection worksheets for all three programs, which can be printed as needed.

The calculations do not consider the location and shape of the application, only information on the lamps is required (including the coefficient of utilization). Therefore, calculations can be done for any outdoor or indoor applications.

For the COST program, the output consists of the installed and annual operating costs on a per luminaire or total system, basis. The cost of light, expressed as dollars per million lumen hours, is shown, and some basic design data is also provided.

For the RETRO program, the initial costs calcuizted are those associated with replacing the existing lamps and ballasts with new, more efficient ones. Annual operating costs for both sys. iems are provided, along with associated savin 5 , return on investment, and payback period for installing the new system.

The PLAN program produces a table showing uxpected results for a range of group relamping and cleaning intervals. These results inelude: the cost of light (dollars per million lumen hours), the percent mean light level, and the annual cost savings compared to spot maintenance.

\section{HAUSER'S LIGHTING AND DAYLIGHTING}

sh

"T2"
This program is very comprehensive: point calculations can be made on both indoor and outdoor applications, and economic analysis for system comparison is produced using the zonal cavity method.

New updated versions of the program are provided free for one year after purchase. Technical support is provided by mail for free, or by phone at an additional charge. The program help screens are designed to respond to the context of the application in use.

The input options feature luminaire selection by specification of performance parameters. To save time, a new job can be input while the printer is working on the last one.

Additional lighting parameters are provided in the output for better measurement of the quality and effectiveness of a lighting system. These include Equivalent Sphere Mluminance, Contrast Rendition Factor, Task Mluminance, and Veiling Luminance.

Graphical outputs of the point calculations bring real life to the designs. Shading graphics are available in two and three point perspective, and can be produced on a dot matrix printer or even with characters on a letter quality printer. If your printer is not among one of those sup. ported, the author will add it to the list.

The costing module of the program may be used for both indoor and outdoor applications of any shape. System comparison results include annual dollar savings, payback period, and return on investment for more efficient alterna. tives. A long or short report format may be selected by the user. 


\section{ILLUMINATION COMIPUTING SERVICE}

"Energy"

In addition to calculating costs, this program evaluates the effects of a maintenance schedule on lighting system performance. It will calcu. late the optimal cleaning and relamping program based on the most light for the fewest dol. lars, unless the user chooses to override this capability with specified in puts.

A large lamp database is included with the program, which contains data on generic luminaires as well as manufacturer data. The data given may also be changed to accommodate any specific luminaire.

The HVAC system costs associated with lighting may or may not be included in the calculations. Default values for the inputs are also available.

Life-cycle costs are given based on a userdefined system life. The savings, payback peri. od, and return on investment are given for alternative systerns.

\section{"Design"}

This is a micro-computer version of the second generation mainframe DESIGN2 program. It uses a perpendicular plane coordinate system for fast and accurate calculations.

The DESIGN data entry program is accessed separately from the calculations program. There are extensive help screens to assist in understanding the data to be entered, and to give genèral information on lighting.

At present the photometric data must be prepared by the user in a specified format. $A$ menu-driven data manager is under development. DESIGN is compatible with the IES rec. ommended format.

The program may be used to design a layout to meet a speciried maintained footcandle level. The point values are calculated producing a luminaire layout recommendation and graphic representation.
The output report is clear and compact. Background input data is given first on the lighting system, and then on the room. A table of the footcandle levels is then given for points on the analysis grid. The total number of luminaires and average level of illuminance are also shown.

"Plane"

This program allows outdoor calculations to be done not only for points along a slanted plane, but for tilted and rotated analysis points as well.

The job data entry program is used separately from the calculations program. There are extensive help screens to assist in understand. ing the necessary inputs, and to give -eneral information on lighting.

At present, the photometric data must be entered by the user in a specified format. A menu-driven data manager is under development, as is compatible with the IES recommended format.

The calculated values may be either the illuminance on one plane, or the illuminance as seen from one location, such as a TV camera. Areas of the analysis grid may be excluded from the calculations, to represent buildings or the boundaries of an intersection.

The outputs consist of one page of general job information, and a second of the point results. Mluminance values at each point are shown for the analysis grid, excluding the masked areas, to show the actual shape of the application.

\section{JOLINKO ENTERPRISES}

\section{"Stlt"}

This software is specifically for roadway calculations. This makes it among the best available for streetlighting layout design.

There are two main programs: one calculates values of illuminance and the other calculates values of pavement surface luminance. The basic version of the packase comes with both of these, as well as a data management program. 
The full-featured package includes versions of the programs which have the option of viewing results on the screen in iddition to printri:s. The data management program and a conversion utility for using IES format data are also included in this package.

Data input may be simplified by choosing a standard layout option. This option produces a grid for luminaire placement established by IES/ANSI RP-8, and is limited to one type of luminaire. With the non-standard layout option, maximum flexibility is provided to the user for specifying luminaires and their placement.

The output contains one page of background information describing the street and lighting $\because$ stem. This is followed by a representation of :ie analysis grid showing the output values at each point. A summary is also provided on the average level, maximum and minimum values, and the uniformity ratio.

The software itself is free of charge. The mini. $\mathrm{mal}$ cost is for the diskette, a reference booklet (user's manual), and shipping.

\section{LIGHTNNG ANALYSIS}

\section{"Point"}

Using PONNT, an outdoor point calculation can be done for skewed light meter orientations as

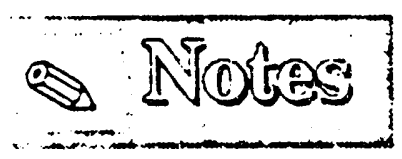

well as sloped planes, in any of the four viewing directions.

In addition to free technical support for the life of the product, user seminars are offered period. ically throughout the year.

Although no photometric data is provided, the program uses the standard IES format. Data in this format is available from several manufacturers.

Input features of the program include mirroring to reduce data entry for symmetric lighting layouts. The ten function keys are also available for options such as changing locations in the input worksheet, or to display menus of all possible entries in certain categories.

There are four supplemental programs available. BATPOINT allows for batch processing of input files without user attention. MULTLUM is a utility to simulate multiple luminaires per location. DIAGRAM provides a floodlight aim. ing ciagram from the input file. PHODIR produces a formatied listing of the descriptive information in photometric data files, and verifies them for completeness and compatibility.

The demonstration disk is free, and can be returned for a fifty dollar discount on purchase of the program. 


\section{LIGHTING TECHNOLOGIES}

\section{"LUMEENS"}

This program performs costing calculations for almost any room shape, such as circular, triangular, L-shaped, and trapezoidal.

Photometric data may be provided through LUMEN-DATA (a photometric database supplied with the program) or, the user can provide Coefficient of Utilization (CU) values directly to the program. Data is provided for generic luminaires from the CU tables in the IES handbook.

Life-cycle costs are determined for a userdefined system life. The calculations include present work analysis and rate of retum on investment for converting to an alternative lighting system. Tax benefits of depreciation on a new system can also be determined and included in the annual costs.

The output is given in a very clear and readable format. A one-page summary of the zonal cavi. ty analysis is provided. The cost information is given first as initial and effective annual operating costs, and then summarized for overall system comparison. A formatted list of the user's input data is also available.

\section{"Lumen-Micro"}

LUMEN-MICRO has undergone many years of development and refinement as it evolved from its mainframe predecessor. The program's authors have written numerous articles about the lighting computation algorithms used in the program.

In addition to providing technical user support over the phone, Lighting Technologies offers two- or three-day workshops quarteriy. These provide hands-on training and assistance in the use of each of their programs.

Although the program's photometrie database comes with only a few luminaires for demon. strative purposes, data on hundreds of lumi. naires are available from many manufacturers in the LUMEN-MICRO format.
Two database "utility" programs are also available. One offers the ability to transfer data records between files, in order to combine and consolidate databases. The other enables the user to export and import files to and from IES standard format.

Flexibility in the outputs allows the user to view any calculated quantity as an iso-contour - or gray-scale shaded rendering. The perspective graphics option provides realistic photographlike pictures. Visual Comfort Probability is available as an output option. This provides a measure of the comfort of a lighting system, taking into account the surrounding glare.

\section{"Lumen Point"}

This program offers the same user-support fea. tures as LUMEN-MICRO, which include handson workshops for training and advanced assistance, held quarterly in Boulder.

The input function of the program includes options which save time during data entry. Luminaires can be entered in groups, or sym. metric designs can be defined and only one half, or one quarter of the layout needs to be entered. Inputs can be made even faster by the use of a digitizer. The software to support this is purchased as a separate option.

Two database utility programs are also available. One offers the ability to transfer dat,a records between files, in order to combine and consolidate databases. The other enables the user to export and import files to and from IES stanciard format.

Outputs can be viewed in several ways. If numerical answers are desirable, tables are available. Graphical representations include iso-contour plots with or without criterion shad. ing, and gray scale shaded plots. Areas within the output region can be masked, for definition of irregularly shaped perimeters or areas not to be considered. The output can be printed in wide or narrow format, and the scale is definable by the user. 


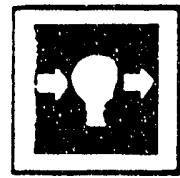

MARSTON, KENNEY, AND ASSOCLATES

"Litcal"

This program was developed by and for consultir.g electrical engineers. It has undergone oneand-a-half years of use and refinement inhouse, and has been made very easy to operate. The program is written in Advance BASIC code, and it may be modified by the user, if desired.

The DOS operating system, version 2.0 or high. er, is also needed to run the program.

The luminaire catalog is accessed separately from the job data and calculations program. Ir.put forms are provided for both the lamp and ico iata, so that the computer data entry may: be cielegated by the designer. A 12 -digit catalog number is used to specify particular luminaires.

The output includes a luminaire schedule that $c=n$ be attached to drawings or included in ecuipment specifications. An output table is $a$ iso given for detailed results by room. The siird output is a cost estimate by luminaire type. This includes the equipment and labor cost of installation, along with energy and demand costs of annual operation.

Revisions to the program will be offered at $\$ 25$ each, as they become available.

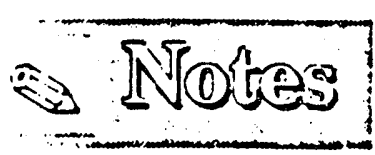

\section{$\mathrm{MC}_{2}$ ENGINEERING}

$\mathrm{E}_{5} \mathrm{M}^{n}$

This program is part of a series, written especially for engineers performing building systems designs. It is written in uncompiled BASIC code, so that the user can modify as desired.

Initial user training at the vendor's office in Miami is offered free of charge.

The zonal cavity method is used to recommend the number and location of fixtures needed to maintain the desired indoor light levels. A suggested layout diagram may be printed.

Photometric data provided with the program include 500 lamps and 500 luminaires (MS DOS version). One hundred or more rooms may be handled in one run, depending upon the computer used.

Other outputs include resultant light level from a specified number of fixtures, and watts per square foot by room or overall. Cost calculations are also performed. They include the cost of luminaires, installation, relamping labor and materials, cleaning labor, and energy for lighting and its heating effects. 
contractors, and distributors, who are unaccustomed to dealing with lighting on a daily basis. All inputs for each job are provided at the sanie time, and include the $C U$ value, so that no lamp database is needed. A worksheet for data input. can be printed, to make data preparation easier.

The one page output includes lighting system layout guidelines as well as the number of luminaires, maintained footcandles, and a list of the user's inputs. For interior systems the recommended system layout may also be presented graphically, either on the screen or printer.

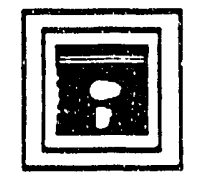

\section{WIICOX PRODUCTIONS}

\section{"Zonalcom"}

A prominent feature of this program, is a simu. lation of the change in lighting level for various maintenance practices. These include the cleaning of luminaires, room refinishing, and group relamping. Extensive cost calculations are also included.

Technical support is offered over the phone for beginning users. At an additional charge, train. ing is available on-site, or in Tulen

The color version of this program makes extensive use of on-screen color to highlight essential information and speed understanding and data entry.

On-screen guidelines for input parameters are presented to assist in data entry, and help screens are readily available.

This program has thorough ealculations for economic analysis, which include the cost of equipment, relamping, and energy for lighting as well as the thermal effects of the lighting system.

The program's output may be customized to be from seven lines to two pages lone.

The demonstration diskette includes Wilcox Production's other two proprams (FLUDWARE and ROADWARE) in an inlegrated package.

\section{"Fludware"}

The calculations in this program are made faster and simpler than most indoor point programs, because luminaires are treated as point sources. To save additional time, inter-reflected light computations are optional, and may be omitted for certain applications.

Technical support is offered over the phone for beginning users. For an additional charge, training is available on-site, or in Tulsa. The program features on-screen guidelines for input parameters to assist in data entry, as well as help screens at the touch of a button.

The color version of this program makes extensive use of on-screen color to highlight essential information and speed understanding and data entry.

The outputs include annual costs for the lighting equipment, relamping, and energy used. A graphic display is available for review of the luminaire locations, and to check data entry.

The demonstration diskette includes Wilcox Production's other two programs (ROADWARE and ZONALCOM) in an integrated package.

\section{"Roadware"}

In addition to performing street and other outdoor lighting calculations, this program computes the cost of the systems designed. Technical support is offered over the phone for beginning users. For an additional charge, training is available on-site, or in Tulsa.

On-screen guidelines for input parameters are presented to assist in data entry, and help screens are available at the touch of $a$ button.

The color version of this program makes extensive use of on-screen color to highlight essential information and speed understanding and data entry. The color value display in ROADWARE helps the operator to quickly determine areas that will be too bright or too dark when installed.

The output contains a chart of the luminaires selected and a luminaire location listing. This shows the position and aiming of each lumi- 


\section{MURRAY AND GIILESPIE COMPUTER SOLUTIONS}

\author{
"Micro-Site-Lite"
}

This program is the micro-computer adaptation of SITE-LITE II from Lighting Sciences, Inc. It features a technique for calculating the optimum pole spacing for street or area lighting. The program accepts up to nine pre-specified uniformity criteria. Roadway luminance calcu. lations can be made using either the IES moving observer or the CIE fixed observer methods of analysis.

To assist in learning, seven working examples are provided on the diskette with the program. These are described in detail in the user's man. ual.

Users may select from a number of calculation options including "TV" Camera Iluminance, Veiling Luminance, Glare Mark, and Windshield Cutoff Angle. The program will calculate the optimum light pole spacing, based upon several uniformity criteria.

The model is flexible enough to include shadows from obstructions. It will handle uneven terrain and irregular shaped areas such as intersections. Output is available in tabular or plotted form, in English or Metric units. Interactive full screen menu and data entry features ease the use of this product.

\section{"Micro-Cost-Lite"}

Although this program may be purchased and used alone, it is designed to be compatible with MICRO-SITE-LITE, and will use the photometric database from that program.

This program covers a wide variety of costs for owning and operating lighting equipment. Included are, purchase and installation costs for lamps, ballasts, luminaires, and electrical wiring. Cost factors considered include taxes, in ierest, inflation, and salvage value. In addition to calculating the total ownership costs, a life-cycle costbenefit analysis and economic payoff period is provided.
User may specify illuminance levels and/or coef. ficient of utilization values (indoor version only). Full screen menus and data entry features ease program use.

\section{"Micro-Eye-Lite"}

This program allows users to select from three computational techniques for indoor lighting analysis. The Zonal Cavity method will determine average illumination levels. The Room Position multiplier and the Flux Transfer methads will calculate light levels at each point for any viewer orientation.

The program outputs include: Horizontal Illuminance levels (with or without body shadow); Vertical Illuminance (across a horizontal or vertical plane, facing any direction); SlopePlane Illuminance (for any slope angle); Luminance (of visual task and background); Visual Comfort Probability; Equivalent Sphere Illumination; Contrast Rendition Factor and Lighting Effectiveness Factor.

Full screen menus and data entry routines are provided. Output may be produced in tabular or plotted form with English or Metric units.

\section{RLH LIGHTNNG CONSULTANTS}

\section{"Light \& Easy"}

This program provides a very fast and simple way to perform calculations for both indoor and outdoor applications. It consists of three modules. The first is for interior lighting, and uses the zonal cavity method. The other two are for outdoor area lighting and flood lighting. These use the lumen, and beam lumen methods, respectively, to calculate the average maintained footcandles or number of luminaires required.

The author provides a one-day seminar on the use of the program. Materials on lighting fundamentals can be included if so desired. For a slightly higher price, additional customization can be added to the program to fit specific user needs.

The program was developed for use by personnel like utility customer service representatives, 
naire. The illuminance values may be shown as a grid of numbers, with both horizontal and vertical illuminance at each point. Altematively, character plots may be produced for either one, using symbols to represent various ranges of illuminance values. One scale and two compressed printouts are available in the report format.

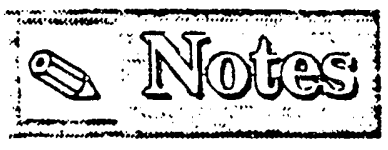

Annual costs are calculated and given for the lighting equipment and energy costs. These can include a user-specified inflation factor.

The demonstration diskette includes Wilcox Production's other two programs (FLUDWARE and ZONALCOM) in an integrated package. 


\section{LIST OF VENDORS}

AMIERICAN TECANICAL SOLUTIONS

R. Pat Hewitt

4475 SW Scholls Ferry Rd., Suite 156

Portland, OR 97225

(503) 292-2863

ELITE SOFTWARE DEVELOPMENT

Terri King

P.O. Drawer 1194

Bryan, TX 77806

(409) $846-2340$

HAUSER'S LIGHTING \& DAYLIGHTIVG

Gregg Hauser

P.O. Box 21-0329

San Francisco, CA 94121.0329

(415) $386-5739$

JOLINRO ENTERPRISES

Merle Keck

8 Lake Boulevard

Vicksburg, MS 39180

(601) 638.0484

\section{LIGETING TECENOLOGIES}

Martin McCloskey

3060 Wainut Street, $\# 209$

Boulder, CO 80301.2530

(303) 449-5791

MARSTON, KINNEY \& ASS()CLATES

William Marston

2775 Crossroads

Grand Junction, CO 81506

(303) 243-2386

\section{RIA LIGHTING CONSULTANTS}

Robert Henderson

4500 Leaf Court

Raleigh, NC 27612

(919) 781-5333
COMPUTER AIDED LIGHTING

ANALYSIS

John Hibbs

P.O. Box 1674

Boulder, CO 80306

(303) 447-2574

GENERAL ELECTRIC COMPAVY

Terty McGowan

Lighting Business Group

Nela Park $\$ 4160$

Cleveland, $\mathrm{OH} 44112$

(216) 266-3234

IILUMINATTON COMPUTING

SERVICE

J. Roy Jones

P.O. Box 162

Arcadia, CA 91006

(818) 574-9695

\section{LIGHTING ANAIYSTS}

Todd Saemisch

10572 East Park Mountain Road

Littleton, CO 80127

(303) $972-8852$

MC2 ENGINEERING

Bob McClintock

P.O. Box 43098

Miami, FL 33143

(305) $665-0100$

MURRAY \& GIILESPIE COMPUTER SOLUTIONS

John Murray

90 Nolan Court, Unit 23

Markham, Ontario L3R 4L9

(416) 477.0260

WILCOX PRODUCTIONS

Timothy Wilcox

P.O. Box 471220

Tulsa, OK 74147.1220

(918) 628-1110 


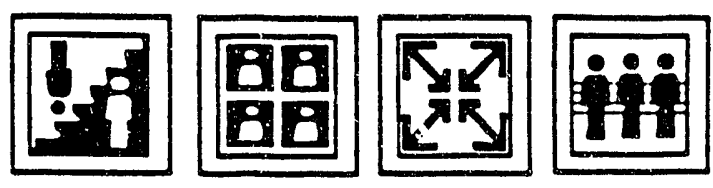

\section{ASSOCIATIONS, AGENCIES, INSTITUTES AND SOCDETIES}

AMERICAN CONSULTING ENGINEERS COUNCLL (ACEC)

1015 15th Street, N.W., Suite 802, Washington, D.C. 20005

AMIERICAN INSTITUTE OF ARCHITECTS (ALA)

1735 New York Avenue, N.W., Washington, D.C. 20006

AMIERICAN INSTITUTE OF PLANT ENGINEERS (AIPE)

3975 Erie Avenue, Cincinnati, OH 45208

AYERICAN NATIONAL STANDARDS INSTITUTE (ANSI)

1430 Broadway, New York, NY 10018

AVERICAN PUBLIC POWER ASSOCLATION (APPA)

2301 M Street, N.W., Washington, D.C. 20037

AVIERICAN SOCIETY OF EEATING, REFRIGERATING AND AUR CONDITIONING ENGINEERS, INC. (ASHRAE)

1971 Tullie Circle, N.E., Atlant3, GA 30329

ASSOCLATION OF ENERGY ENGLNEERS (AEE)

4025 Pleasantdale Road, Suite 340, Atlanta, GA 30340

ASSOCLATION OF PHYSICAL PLA'T IT ADNTNISTRATORS OF UNTVERSTTLES

AND COLLEGES (APPA)

11 Dupont Circle, Suite 250, Washington, D.C. 20036

ASSOCLATION OF PROFESSIONAL ENERGY MANAGERS (APEM)

3104 O Street, Suite 301, Sacramento, CA 95816

BUIDDNG OWNERS AND MANAGERS ASSOCLATION INTERNATIONAL (BOMLA)

1221 Massachusetts Avenue, N.W., Washington, D.C. 20005

CERTIFIED BAILAST MANUFACTURERS ASSOCLATION (CBMA)

2122 Keith Building, Cleveland, OH 44115

EDISON ELECTRIC INSTITUTE (EEI)

1111 19th Street, N.W., Washington, D.C. 20036

ELECTRIC POWER RESEARCH INSTITUTE (EPRD)

- 9412 Hillview Avenue, Palo Alto, CA 94304 
ENERGY MANAGEMEST AND CONTROLS SOCLETY (EMCS)

1925 North Lynn Street, Arlington, VA 22209

IILUMINATLNG ENGINEERING SOCLETY OF NORTH AMERICA (IES)

345 East 47th Street, New York, NY 10017

INSTTTUTE OF ELECTRICAL AND ETECTRONICS ENGINEERS, INC. (IEEE)

345 East 47 th Street, New York, NY 10017

INSTITUTE OF ENVIRONMENTAL SCIENCES (IES)

940 E. Northwest Highway, Mt. Prospect, IL 60056

INSTITUTE OF INDUSTRIAI ENGINEERS (IIE)

25 Technology Park, Atlanta, GA 30092

INSTRUMENT SOCIETY OF AMERICA (ISA)

P.O. Box 12277, Research Triangle Park, NC 27709

INTER.NATIONAL ASSOCLATION OF ELECIRICAN, LEAGUES (LAEL)

2101 L Street, N.W., Washington, D.C. 20037

INTERNATIONAL ASSOCLATION OF LIGHTING DE BILNERS (IALD)

40 East 49th Street, New York, NY 10017

NTTERNATIONAL ASSOCLATION CF LIGHTING MAINTENANCE

CONTRACTORS (LALMC)

2017 Walnut Street, Philadelphia, PA 19103

INTERNATIONAL ASSOCLATION OF LIGHTING MANAGEMENT COMPANIES (LALMC)

379 Princeton-Hightstown Road, Cranbury, NJ 08512

LAWRENCE BERKELEY LABORATORY (LBL)

No. 1 Cyclotron Road, Berkeley, CA 94720

LIGFTIN ; RESEARCH INSTIYUTE (LRD)

345 East 47th Street, New York, NY 10017

MANUFACTURERS OF ILIUMMNATION PRODUCTS (MDP)

158-11 Jewell Avenue, Room 307, Flushing, NY 11365

NATIONAL ASSOCLATION OF EILCTRICAL DISTRIBUTORS (NAED)

600 Summer Street, Starnford, CT 06901

NATIONAL ASSOCLATION OF POWER ENGINEERS, INC. (NAPE)

176 W. Adams Street, Suite 1914, Chicago, IL 60613

NATTONAL ELECTRICAL CONTRACTORS ASSOCLATION, INC. (NECA)

7315 Wisconsin Avenue, 13th Floor, Washington, D.C. 20037 
NATIONAL ELECTRICAL MANUFACTTRERS ASSOCLATION (NEMA)

2101 L Street, N.W., Washington, D.C. 20037

NATIONAL INSTITUTE OF BUILDING SCIENCE (NI )

1015 15th Street, N.W., Suite 700, Washington, D.C. 20005

NATIONAL LIGHTING BUREAU (NLB)

2101 L Street, N.W., Washington, D.C. 20037.

NATIONAL SOCIETY OF PROFESSIONAL ENGINEERS (NSPE)

2020 K Street, N.W., Washington, D.C. 20006

THE ELECTRIFICATION COUNCI

1111 19th Street, N.W., Washington, D.C. 20036

UNITED STATES GOVERNMENT AGENCIES

U.S. DEPARTMENT OF ENERGY (U.S. DOE)

Assistant Secretary for Conservation and Renewables,

1000 Independence Avenue, Washington, D.C. 20585

NA JNAI INSTITUTE OF STANDARDS AND TECGNOLOGY (NIST)

Building Equipment Division, Center for Building Technology,

Washington, D.C. 20234

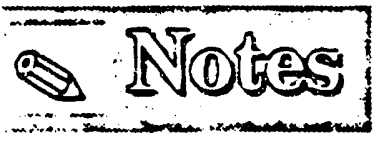




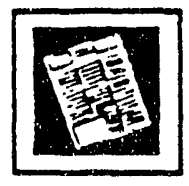

\section{LIGHTING PUBLICATIONS}

The following publications list includes a sampling of articles, handhooks, and other lighting references. Major lighting references are included. Other entries are intended to be representative of published resources. The titles, authors, and organizations cited show the wide variety of sources.

\section{REPORTS}

"BEPS Research Yield New Energy Data for Design Energy". The Newsletter of AIA Energy Notebook, American Institute of Architects, February, 1980.

Computers in Lighting-Computers and Lighting Calculations. Lighting Design \& Application, June 1986.

Control Data Computer Installation Case Study. National Lighting Bureau, Washington, D.C., i984.

C aylighting Design Tool Survey. DA 170, Pre-publication, January 1986, Windows and Daylighting Group.

Design Fundamentals for Nonuniform Lighting. National Electrical Contractors Association, Washington, D.C., Decernber, 1974.

Enviro-Management \& Research, Inc. Total Energy Management Kit. National Electrical Contractors Association, Washington, D.C., 1980.

Enviro-Management \& Research, Inc. Characteristics of Commercial Sector Buildings and Their Use and Demand. Electric Power Research Institute, Palo Alto, California (forthcoming).

EPRI Guide: Technical Reports Published Lighting Handbook for Utilities. EPRI EM-423, Energy Power Research Institute, April 1986.

Fundamentals of Commercial and Industrial Lighting. Fifth Edition, The Electrification Council, Washington, D.C., 1983.

Guidelines for Saving Energy in Existing Buildings, Vol. I \& II. U.S. Department of Energy, U.S. Government Printing Office, Washington, D.C., July 16, 1975.

High Intensity Discharge Lamps. General Electric Company, Cleveland, Ohio, 1975.

Lighting Energy Controls. National Electrical Contractors Association, Washington, D.C., March 1981.

Lighting Energy Management ia Kediling. National Lighting Bureau, Washington, D.C., 1984.

Lighting Manual Reference. National Association of Electrical Distributors, Research Foundation, Inc. Stamford, Connecticut, 1982.

Luminaire Selection and Specification. National Electrical Contriztors Association, Washington, D.C., June 1980.

Office Lighting Practice. National Electrical Contractors Association, Washington, D.C., December 1978.

Personal Computez Software for Lighting Design and Analysis. EPRI EM-5463, Energy Power Research Institute, October 1987. 
Survey of Utility Lighting Programs. Report EM-5093, Electric Power Research Institute, Final Report, February 1987.

The Automated Office - An Environment for Productive Work or an Information Factory?: A Report on the State-of-the-Art. General Services Administration, Public Buildings Service, Washington, D.C., November, 1983.

The Energy-Saver's Guide to Good Outdoor Lighting. National Lighting Bureau, Washington, D.C., 1983.

The Lighting Energy Workshop. Edison Electric Institute and Electric Power Research Institute, Washington, D.C., March 29-30 1982.

Toward Improved Lighting Quality. National Electrical Contractors Association, Washington, D.C., December 1977.

White Collar Productivity: The National Challenge. The American Productivity Center, Houston, Texas, 1982.

\section{BOOKS AND PERIODICALS}

A Guide to the Photovoltaic Revolution. \#PB-10-85; Published by Rodale Press, 1985; ISBN \#08785i-534-0.

A Method of Evaluating the Visual Effectiveness of Light Systems. \#LM-33-70; Illumination Engineering Society, 1970.

AV Catalog. National Association of Electrical Distributors, Inc., 1989.

Airport Road and Automobile Parking Area. \#RP 17.87; Illumination Engineering Society, 1987.

Airport Service Area Lighting. "RP.14-87; Illumination Engineering Society, 1987.

Approved Method of Reflectometry. "LY-44-85; Mlumination Engineering Society, 1985.

Architectural Graphic Standards 8th Edition. "PB-32-88; Published by Ramsey \& Sleeper, 1988 ; ISBN $\# 0-417-81148-3$.

Architectural Lighting for Commercial Interiors. \#PB-26-87; Published by John Wiley \& Sons, Inc., 1987; ISBN *0-471-01168-1.

Astronomical Light Pollution and Light Trespass. \#CP-46-85; Mlumination Engineering Sasiety, 1985.

Basic Lighting Manual. National Association of Electrical Distributors, Inc., 1989

Building Additions Design. "PB-2.85; Published by MeGraw Hill, 1985; ISBN 00-07-063403-3.

CAD/CAM Handbook \#PB-3-85; Published by McGraw Hill, 1985; ISBN \#0-07-063403-3.

Calculating Coefficients of Utilization, Wall Exitance Coefficients, and Ceiling Cavity Exitance Coefficients. "L.M-57-82; Illumination Engineering Society, 1982.

Calculation of Daylight Availability. \#P.21-84; Illumination Engineering Society, 1984.

Choosing Light Sources for General Lighting. "CP-32-88; Illumination Engineering Society, 1988.

Commercial Lighting Marketing Textbook National Association of Electrical Distributors, Ine., 1989. 
Daylighting. MP-5-79; Illumination Engineering Society, 1979.

Daylighting-Design and Analysis. "PB-24-86; Published by Van Nostrand Reinhold, 1986; ISBN \#0-442-27949-3.

Dennis J. Hocker. Would You Believe an Under-Six-Day-Payback on a $\$ 51,000$ Lighting Investment? Contractors Lighting Equipment, October, 1983.

Design Considerations for Effective Building Lighting Energy Utilization. \#LEM-3-87; Illumination Engineering Society, 1987.

Design Criteria for Lighting Interior LivingSpaces. \#RP-11-80; Illumination Engineering Society, 1980.

Design Fundamentals for Nonuniform Lightirg. \#30258; Vational Electrical Contractors Association.

Design Presentation: Techriques for Marketing and Project Proposals. \#PB-6-83; Published by McGraw Hill, 1983.

Designing Buildings That Work. \#PB-1-85; Published by .McGraw Hill, 1985; ISBN \#0-07. 047952-6.

Designing with the IES Roadway Lighting Practice. \#ED-3A-84; Illumination Engineering Society, 1984.

Directory of State Building Codes and Regulations. \#PB-16-85; Published by National Conference of State Building Codes and Standards, 1987;

Educational Facilities Lighting. \#RP-3-88; Mlumination Engineering Society, 1988.

Electrical and Photometric Measurements of Low Pressure Sodium (LPS) Lamps. \#LM-59. 83; Illumination Engineering Society, 1983.

Electrical and Photometric Measurements of General Service Incandescent Filament Lamps. \#LM-45-81; Illumination Engineering Society, 1981.

Electrical Contractor magaaine. National Electrical Contractors Association.

Electrical Wiring. National Association of Electrical Distributors, Inc., 1989.

Energy Analysis of Building Lighting Design and Installation. "LEM-4-84; Illumination Engineering Society, 1985.

Energy Users News. Fairchild Publications.

Getting the Most From Your Lighting Dollar (2nd Ed.) National Lighting Bureau.

Handbook of Practical Electrical Design. "PB-4-84; Published by McGraw Hill, 1984; ISBN \#0. 07.045695-X

Heaith Care Facilities. \#CP-29-85; Illumination Engineering Society, 1985.

HWO Lighting: Its Applications and Benents. "302515; National Electrical Contractors Association.

IES Approved Guide for Identifying Operating Factors for Installed High Intensity Discharge (HDD) Luminaires, *LM.61-86; Illumination Engineering Society, 1986.

IES Approved Guide for Laboratory or Field Thermal Measurements of Fluorescent Lamps and Ballasts in Luminaires. "LM-62-85; Illumination Engineering Society, 1985. 
IES Approved Method for Life Testing of General Lighting Incandescent Filament Lamps. \#LM-49-86; Illumination Engineering Society, 1986.

IES Approved Method for Life Performance Testing of Fluorescent Lamps. "LM-40-87; Illumination Engineering Society, 1988.

IES Approved Method for Life Testing of High Intensity Discharge (HD) Lamps. \#LM-4787; Illumination Engineering Society, 1987.

IES Approved Method for the Electrical and Photometric Measurements of Fluorescent Lamps. \#LM-9-88; Ilumination Engineering Society, 1988.

IES Approved Method for Photometric Testing of Roadway Luminaires. \#LVI-31-88; Illumination Engineering Society, 1986.

IES Guide for Photometric Measurement of Roadway Sign Installation. \#LM-52-85; Illumination Engineering Society, 1985.

IES Guide for Measurement of UItraviolet Radiation from Light Sources. \#LM-55-84; Illumination Society, 1984.

IES Guide for Calibration of Photoelectric Control Devices. \#L.M-48-84; Illumination Engineering Society, 1984.

IES Guide for Photometric Measurement of Roadway Lighting Installations. \#L.M-50-85; Illumination Engineering Society, 1985.

IES Guide for Reporting General Lighting Equipment Engineering Data for Indoor Luminaires. \#LM-15-87; Mlumination Engineering Society, 1987.

IES Guide to Lamp Seasoning. \#LM1-54-84; Illumination Engineering Society, 1984.

IES Guidelines for Unit Power Density (UPD) for New Roadway Lighting Installations. \#LEM-6-87; Illumination Engineering Society, 1987.

IES Lighting Eandbook, Application Volume. \#HB-A-87; Illumination Engineering Society, 1987.

IES Lighting Handbook, Reference Volume. \#HB-A-84; Illumination Engineering Society, 1984.

IES Lighting Handbook. Chapter 9, Lighting Calculations; Reference Volume, Illuminating Engineering Society of North America, 1982.

IES Lighting Ready Reference. \#R-85; Illumination Engineering Society, 1989.

IES Lighting Survey Form A. "L.M1-21-63; Illumination Engineering Society, 1963.

IES Recommended Practice for Library Lighting. *RP-4-74; Illumination Engineering Society, 1974.

IES Recommended Standard File Format for Electronic Transfer of Photometric Data. - LM-63-86; Illumination Engineering Society, 1986.

Mlumination Enginecring for Energy Efficient Luminous Engineering. \#PB-15-80;

Published by Prentice-Hall, 1980; ISBN 0-13-450809-2.

Dlumination Engineering. "PB-12-85; Published by McGraw Hill, 1985; ISBN 007-582387-9.

Index and Directory of U.S. Industry Standards. \#PB-8-84; Published by Information Handling Services, 1984; ISBN $\because 0-89847-008-0$. 
Industrial Lighting Handbook. National Lighting Bureau, Washington, D.C., Industrial Lighting. ARP-7-83; Mlumination Engineering Society, 1983.

Interior Lighting for Environmental Designers. "PB-27-83; Published by John Wiley \& Sons, Inc., 1986; ISBN \#2-0471-87381-0.

Interior Lighting of Public Conveyances-Road and Rail. 1 CP-12-74; Mlumination Engineering Society, 1974.

Introductory Lighting Education on Videotape (Lighting Fundamentals I, II, III). Illumination Enginee gociety, 1986.

Introductory Lighting Education. \#ED-100-85; Illumination Engineering Society, 1985.

John P. Nix. "Charge of the Light Brigade." The American School Board Journal, July, 1982.

Journal of The IES. Illumination Engineering Society, 1989.

Lamps and Lighting. \#PB-11-83; Published by Routledge, Chapman and Hall, 1983; ISBN \#0-7131-3487-9.

Lamps and Luminaires (Lighting Fundamentals IV). Illumination Engineering Society, 1989.

Lawrence G. Byrnes. "Retrofit Lights Up Center's Bottom Line." Shopping Center World, p. 60. 1984.

Life Testing of Low Pressure Sodium (LPS) Lamps. \#LM-60-83; Illumination Engineering Society, 1983.

Light Light Light - Effective Use of Daylighting and Electrical Lighting in Residential and Commercial Spaces. \#PB-11-89; Published by Durwood Publishers, 1989; ISBN \#0-13-450809-2.

Lighting, Design and Application Magazine. Mluminating Engineering Society (IES) Of North America.

Lighting Energy Controls. \#302533; National Electrical Contractors Association.

Lighting Energy Management for Colleges and Universities. National Lighting Bureau, Washington, D.C., 1983.

Lighting Energy Management in Retailing (2vd Ed.) National Lighting Bureau.

Lighting Energy Management for Offices and Office Buildings. National Lighting Bureau, Washington, D.C., 1982.

Lighting Equipment Options for Modern Buildings. \#302564; National Electrical Contractors Association.

Lighting for Aircraft/Airliwe Industries. \#CP.40-78; Illumination Engineering Society, 1978.

Lighting for Parking Facilities. "RP-20-85; Illumination Engineering Society, 1985.

Lighting for Theatrical Presentations on Educational Commuaity Prescenium-Type

Stages. "CP.34-83; Illumination Engineering Society, 1983.

Lighting Handbook. Westinghouse Electric Corporation, Bloomfield, New Jersey, 1974.

Lighting Hardbook. (IES Handbook Condensed) Phillips Lighting Company.

fighting in the Logging and Smwrill Industries. "CP-42-86; Mlumination Engineering Society, 1986.

Lighting Mathematics. ED-200.1.88; Illumination Engineering Society, 1986. 
Lighting Merchandising Areas. \#RP.2.86; Illumination Engineering Society, 1986.

Lighting Outdoor Locations of Electric Generating Statious. \#CP-8-75; Illumination Engineering Society, 1975.

Lighting Power Lighting Determination. \#LEM-2-84; Illumination Engineering Society, 1985.

Lighting Roadway Safety Rest Areas. \#CP-38-85; Illumination Engineering Society, 1985.

Lighting Your Way to Safety, Security and Savings. National Lighting Bureau.

Luminaire Selection \& Specification. \#302530; National Electrical Contractors Association.

Nomenclature and Definitions for Mluminating Engineering. \#RP-16-86; Illumination Engineering Society, 1980.

Nuclear Power Plan Lighting. \#CP-41-76; Illumination Engineering Society, 1976.

Office Lighting. \#RP-1-82; Illumination Engineering Society, 1982.

Office Lighting Practice. \#302524; National Electrical Contractors Association.

Outdoor Lighting Management. \#302554; National Electrical Contractors Association.

Payback Benefits of Better Lighting. \#302540; National Electrical Contractors Association.

Performing a Lighting System Audit (Revised Edition). National Lighting Bureau.

Photometric Testing of Reflector Type Lamps. \#LM-20-83; Illumination Engineering Society, 1983.

Photometric Testing of Searchlights. \#L.M-11-84; Illumination Engineering Society, 1984.

Photometric Testing of Outdoor Fluorescent Luminaires. \#LWI-10/10A-88; Illumination Engineering Society, 1988.

Photometric Testing of High Intensity Discharge (HDD) Lamps. \#LM-51-84; Illumination Engineering Society, 1984.

Photometric Testing of Lndoor Fluorescent Luminaires. \#LWI-41-85; Illumination Engineering Society, 1985.

Photometric Testinz of Indoor Luminaires Using High Intensity Discharge (FWD) Lamps. \#LM-46-85; Illumi-ation Engineering Society, 1985.

Planniog \& Desi 6 ing Lighting - By: Edward Effron. \#PB-31-88; Published by Little Brown \& Company, 1988; ISBN \#0-316-21235-0.

Practical Guide to Colormetry of Light Sources. \#L.M-16-84; Illumination Engineering Society, 1984.

Profiting From Lighting Moderaization. National Lighting Bureau.

Road Lighting. \#PB-21-80; Dist. by Scholium International, Inc., 1980; ISBN \#90-201-12597.

Roadway Lighting Fundamentals Course. MED-3-78; Illumination Engineering Society, 1978.

Roadway Lighting. \#RP-8.83; Mlumination Engineering Society, 1983.

Roadway Sign Lighting. "RP.19-83; Illumination Engineering Society, 1983.

Robert F. Ringel. "Energy Management Can Save More Than Wattage." American School \& University, June 1982, p. 34. 
Russell Allen, "Pennsylvania Power and Light: A Case Study." Buildings, March 1982, p. 49.

Selection, Care and Use of Electrical Instruments in the Photometric Laboratory. \#LM-28. 80; Illumination Engineering Society, 1980.

Solving the Puzzle of VDT Viewing Problems. National Lighting Bureau.

Spectroradiometric Measurements. \#L.M-58-83; Illumination Engineering Society, 1983.

Sports Lighting. \#RP-6-89; Illumination Engineering Society, 1989.

Stage Lighting-A Guide to the Planning of Theatre and Public Building Auditoriums. *CP-45-83; Mlumination Engineering Society, 1983.

Sunlighting as Formgiver for Architecture. \#PB-23-86; Published by Van Nostrand Reinhold, 1986; ISBN $\# 0-442-25941-7$.

Task Lighting Considerations. \#302520; National Electrical Contractors Association.

Temporary Electrical Facilities. \#302550; National Electrieal Contractors Association.

The Best of Lighting Design. \#PB-29-87; Published by PBC Incernational Inc., 1987; ISBN \#0. 86636-017-4.

The Bottom-Line Benefits of Retrofitting Exterior Lighting. Building Operating Management, May 1983.

The Language of Lighting. Halo Lighting Division, McGraw-Edison Company, 1983.

The Lighting BandBook for Utilities. Report E.1-4423, Electric Power Research Institute, April, 1986.

The NLB Guide to Office Lighting and Productivity. Nasional Lighting Bureau.

The NLB Lighting Benefits Series: Lighting and Industrial Productivity., Lighting and Retail Sales., Lighting and Security., National Lignting Bureau.

Theatre, Television and Film Lighting Glossary. \#CP.4+83; Illumination Engineering Society, 1983.

Toward Impioved Lighting Quality. \#302512; National Electrical Contractors Association.

Tunnel Lighting. "RP-22-87; Illumination Engineering Society, 1987.

Understanding Eler:ricity and Electrical Terms. National Association of Electrical Distributors, Inc., 1989.

Views on the Visual Environment. $\#$ RP.22-87; Illumination Engineering Society, 1987.

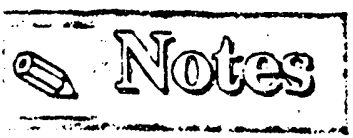


Report and Information Sources

Additional copies of this report, "Local Government Involvement in Long Term Resource Planning for Community Energy Services," are available from:

Publications and Distribution

Public Technology, Inc.

1301 Pennsylvanina, N.W.

Washington, D.C. 20004

For additional information on the process and the results of the work described in this report please contact:

Burton E. Waite, Jr.

Energy Coordinator

Office of Energy and Environment

City of Tucson

P.0. Box 27210

Tucson, Arizona 85726-7210 


\section{Publications Price List--UCETF Reports}

TITLE

PRICE

15.00

15.00

15.00

15.00

15.00

15.00

10.00

15.00

89-321 Summary of Low and Moderate Income Residential Energy Cunservation Programs

15.00

89-315 A Case Study in the Pursuit of Urban Energy Efficiency

15.00

89-314 Communicating with the Public About Environmental Health Risks: A Case Study

13.00

89-313 Evaluation and Comparison of Selected Household Hazardous Waste Collection Facilities

15.00

89-311 Yard Waste Recycling Study: A Pilot Study

15.00

89-310 Sludge Storage Lagoon Biogas Recovery and Use, Volume 1

15.00

89-307 Proceeding: 1989 Electric Utility Franchise Conference

20.00

$89-306$

Reducing Electricity Demand Through Energy-Related Efficient Construction

15.00

89-304 Modernization of Lighting in Municipal Auditoriums

15.00

89-303 Wastewater Treatment Process Energy Optimization

13.00

89-301 Implementation of Alternative Technologies through the Assessment of Energy Markets

14.00

88-322 Marketing Energy Efficiency Programs to Commercial and Industrial Firms: Lighting Incentives and

15.00

88-321 Urban Energy Management Today: 'Ten Year Cumpendium of UCETF Programs

10.00

$88-319$ Integrating Energy Efficiency Into Municipal Purchasing Decisions: Computerizing Procurement

15.00

88.318 Household Hazardous Waste: Implementation of a Permanent Collection Facility

20.00

88-317 Hazardous Waste as an Energy Manager's Issue

15.00

88-316 Household Hazardous Waste Management Planning

15.00

88-312 Summary of Small Business Energy Conservation Programs

15.00

$88-310$

$88-309$

The Earth-Coupled Heat Pump: Utilizing Innovative Technology in Single Family Rehabilitation

15.00

8n-309 Energy Planning for Economic Development

18.00

88-308 Conversion of Resource Recovery Steam to Hot and Chilled Water Systems

10.00

88-306 HVAC Equipment Replacement for Best Size and Efficiency, Transfer Report

15.00

$88-305$ Cogeneration and Cooling in Small Scale Applications

15.00

$88-304$

Energy Master Planning: Innovative Design and Energy Analysis Services for New Commercial

22.00

$88-303$

$88-302$ Energy Efficient Building Design: Guidelines for Local Government

15.00

Direct Digital Control of Air Washer Cooling System

15.00

88-301

Feasibility Study of Transportation Management Strategies in the Poplar Corridor, Memphis, Tennessee

87-327 Energy Effiicient Urban Cooling Technologies: 1st National Conf.

87-324 Memphis Area Rideshare

18.00

20.00

15.00

$87-317$

Joint City Government/Utility Partnerships to Reduce Business Costs

15.00

87-314 The Impact of Budgetary Incentives on Energy Management 
Publications Price List--UCETF Reports

TITLE

PRICE

20.00

87-313 Computer Assisted Control for Municipal Water Systems, Phase II

87-312 Economic Development Through Energy Technology Tranfer 15.00

87-311 Electric Utility Franchise Guide 20.00

87-310 Hidden Link: The Energy and Economic Development, Phase II 15.00

87-307 Municipal Underground Storage Tanks: An Energy Manager's Guide 18.00

87-306 Intergrating Energy Efficiency into Mun. Purchasing Decisions 20.00

87-305 Energy Enhancement in New Residential Construction 40.00

87-302 Thermal Energy Storage: Application Guide for Local Governments 20.00

87-301 HVAC Equipment Replacement for Best Size \& Efficiency 20.00

86-315 Balancing Single Pipe Steam Heating Sytems 20.00

86-314 Inhibition of Respiration in Activated Sludge by High Carbon Dioxide Concentration 7.50

86-313 Water Supply System Energy Conservation Through Computer Control 18.00

86-312 Energy Cost Reduction Through Wastewater Flow Equalization 20.00

86-311 High Efficiency Gas Furnace Modification in Low Income Housing 15.00

86-310 Hidden Link: Energy and Economic Development, Phase I 15.00

86-307 Disposal Techniques with Energy Recovery for Scrapped Vehicle Tires 20.00

86-306 District Heating Marketing: Analysis of a Twelve City Survey 20.00

36-305 Technology Transfer for Residential Energy Programs in New Construction a nd Existing Housing 15.00

86-304 Technology Transfer for Residential Energy Efficiency 15.00

86-302 Neighborhood Energy Efficiency \& Reinvestment 15.00

$86-301 \quad$ On-Site Municipal Fuel Cell Power Plan: Feasibility and Application Guide 15.00

85-326 Resource Recovery for Urban Yard Waste 18.00

85-323 Energy Monitoring and Controlling in Municipal Facilities 10.00

85-320 Transportation Management for Business Relocation 15.00

85-319 District Heating in Denmark 10.00

85-318 Computer-Assisted Control for Municipal Water Systems, Phase I 18.00

85-317 Financing Energy Efficient Housing as a Community Economic Development Tool 15.00

85-316 Modular District Heating Planning as a Development Tool 15.00

85-314 Alternativa Techniques for Dev. of Energy Efficient Residences 15.00

85-312 Shared Savings and Low Income Homeowners 18.00

85-311 Measures and Investment Options for Community Energy Conservation 18.00

$85-310 \quad$ Planning for Energy Efficiency in New Commercial Buildings 15.00

$85-308 \quad$ Residential Space Heating with Wood 15.00

85-307 Thermal Storage Strategies for Energy Cost Reduction 18.00

84-325 Shared Savings in the Residential Market

84-324 Methanol Use in Vehicle Fleet Operations: Barriers 20.00

84-322 Energy Management and Technology for Urban Governments 15.00

84-321 Hydrate Process for Waste Water Treatment Plant Sludge Dewatering 15.00 


\section{Publications Price List--UCETF Reports}

TITLE

PRICE

15.00

15.00

18.00

10.00

15.00

22.00

20.00

15.00

15.00

15.00

15.00

15.00

84-303 Innovative Finance Plans for Privately Owned Waste/ Vol. 1

15.00

84-301

Coordinating Preventive Maintenance with Energy Management

15.00

83-319 The Rehabilitation and Retrofit of Older Houses to Superinsulated Standards

20.00

83-318

$83-316$

Developing Sources and Techniques for Alternative Financing of Energy Conservation

10.00

83-315

Hydrate Process for Dewatering Sewage Sludge

15.00

Financial Planning for District Heating: Brooklyn Navy Yard

18.00

83-314 Memphis Area Rideshare On-Line Information System

18.00

83-313 Renovation Opportunities for Steam District Heating Systems

20.00

83-312

Initial Assessment of District Heating and Cooling

18.00

83-311 Energy Conservation Through Computerized Automation

15.00

83-309 Development of an Energy Park: Issues and Implementation Options

15.00

83-308 Alternative Uses for Digester Methane Gas

83-307

Innovative Financing and Incentive Package to Reduce Energy

15.00

83-305 Multi-Jurisdictional Planning for District Heating and Cooling

10.00

$83-303$

Improving Energy Management and Accountability in Municipal Operations

15.00

82-320 Utilization of Felled City Trees as Supplemental Boiler Fuel

7.50

82-319 Methanol Use in Vehicle Fleet Operations: Comparisons

15.00

82-317 Microcompter Tools for Trans. and Residential Energy Conservation

20.00

82-316 Reduction of Impediments to Alternative Energy Use

20.00

82-315 Reducing Regulatory and Financial Impediments to Energy Conservation

20.00

82-314 Integrating Energy Management with Economic Development

20.00

82-313 Energy Conservation and Economic Development

10.00

82-310 Municipal Technologies

82-307 Strategies to Improve Community Energy Use Practices

10.00

82-306 Energy Conservation In Water Treatment

82-305 Development of an Energy Action Plan: Participating Approach 
Publications Price List--UCETF Reports

TITLE

ITEM \#

PRICE

10.00

\begin{tabular}{|c|c|c|}
\hline $82-300$ & Developing an Energy Management Tracking System & \\
\hline $81-328$ & Matching End Use Energy Needs to Source Possibilities & 20.00 \\
\hline $81-327$ & Development of a Hydrogen-Fueled Mass Transit Vehicle s & 15.00 \\
\hline $81-326$ & Operational and Maintenance Guidelines for Reducing Energy Consumption & \\
\hline $81-324$ & Energy Management for Small Business & 10.00 \\
\hline $81-320$ & Energy Data Gathering, Analysis, and Review System & 20.00 \\
\hline $81-318$ & Fuel Management and Planning System for Local Government & 25.00 \\
\hline $81-316$ & Production of Ethanol from Cellulosic Fraction & \\
\hline $81-313$ & Metro-Dade County Comprehensive Energy Emergency Plan & \\
\hline $81-311$ & Developing Energy Emergency Prepardness & 15.00 \\
\hline $81-310$ & Simplified Methodology for Community Energy Management & 20.00 \\
\hline $81-309$ & Energy Management: The Public Sector & 15.00 \\
\hline $81-307$ & Municipal Technical Assistance-Energy Monitoring & 6.00 \\
\hline $81-306$ & New Technology Demonstration & 10.00 \\
\hline $81-305$ & Technology Transfer: Unit Report from the Energy Task Force & 15.00 \\
\hline $81-304$ & Development of Local Energy Management Preparedness & 10.00 \\
\hline $81-303$ & Municipal Energy Management & 10.00 \\
\hline $80-314$ & Methodology for Energy Impact Analysis of Uroan Development Projects & 15.00 \\
\hline $80-313$ & Evaluation of Landfill Gas as an Energy Source & 15.00 \\
\hline $80-309$ & Decision Process for the Retrofit of Municipal Buildings & 20.00 \\
\hline $80-308$ & Primary Urban Energy Management Planning Methodology & 7.50 \\
\hline $80-306$ & Local Government Use of Thermography for Energy & 15.00 \\
\hline $79-300$ & Planning for and Purchasing Computer Technology & 6.50 \\
\hline
\end{tabular}



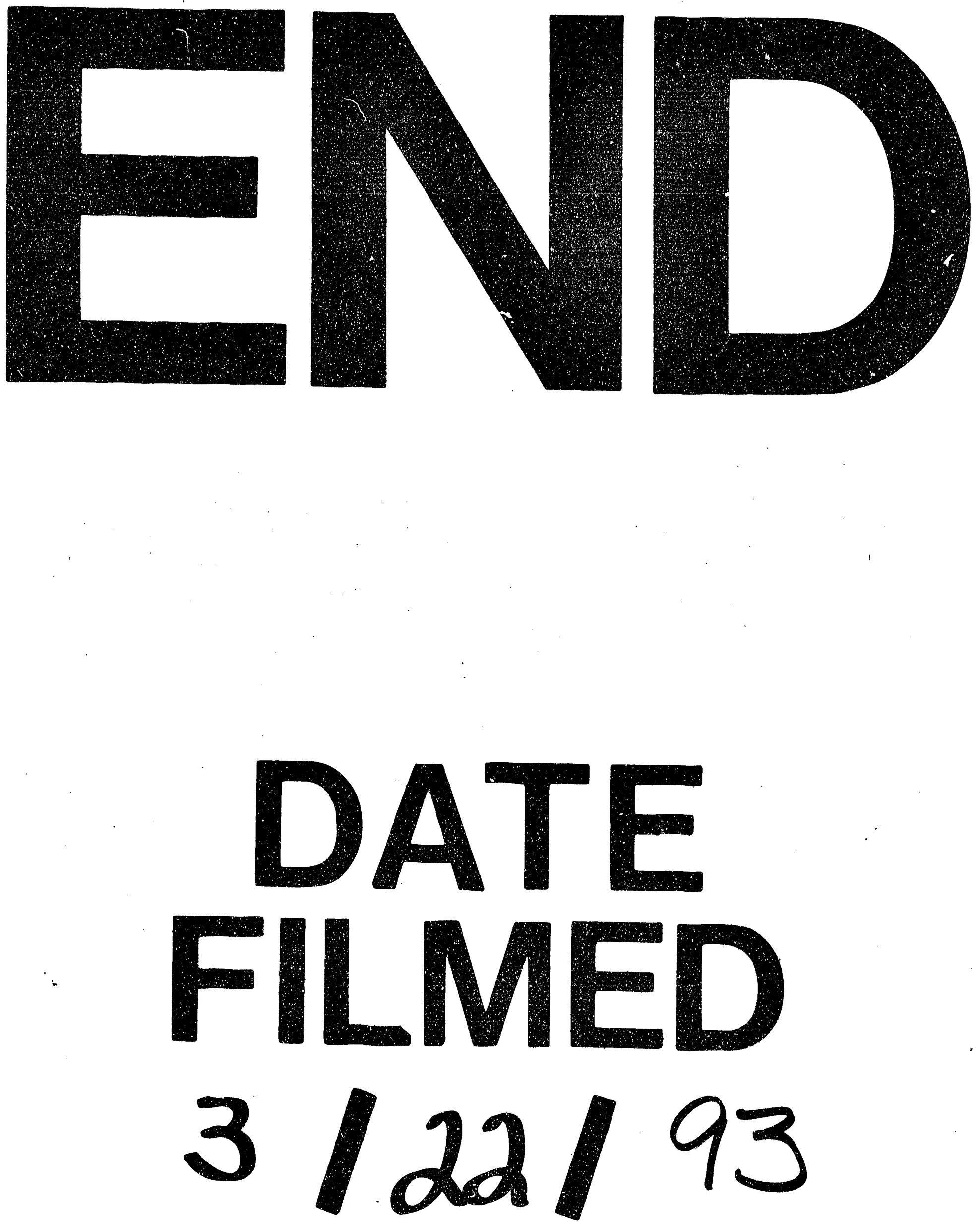